\title{
Governing Transformation towards Low-carbon Societies: An ideational perspective from developing countries
}

Henrysson, Maryna

Publication date:

2017

Document Version

Publisher's PDF, also known as Version of record

Link back to DTU Orbit

Citation (APA):

Henrysson, M. (2017). Governing Transformation towards Low-carbon Societies: An ideational perspective from developing countries. UNEP DTU Partnership.

\section{General rights}

Copyright and moral rights for the publications made accessible in the public portal are retained by the authors and/or other copyright owners and it is a condition of accessing publications that users recognise and abide by the legal requirements associated with these rights.

- Users may download and print one copy of any publication from the public portal for the purpose of private study or research.

- You may not further distribute the material or use it for any profit-making activity or commercial gain

- You may freely distribute the URL identifying the publication in the public portal

If you believe that this document breaches copyright please contact us providing details, and we will remove access to the work immediately and investigate your claim. 


\section{GOVERNING TRANSFORMATION TOWARDS LOW-CARBON SOCIETIES}

An Ideational Perspective from Developing Countries

Maryna Henrysson

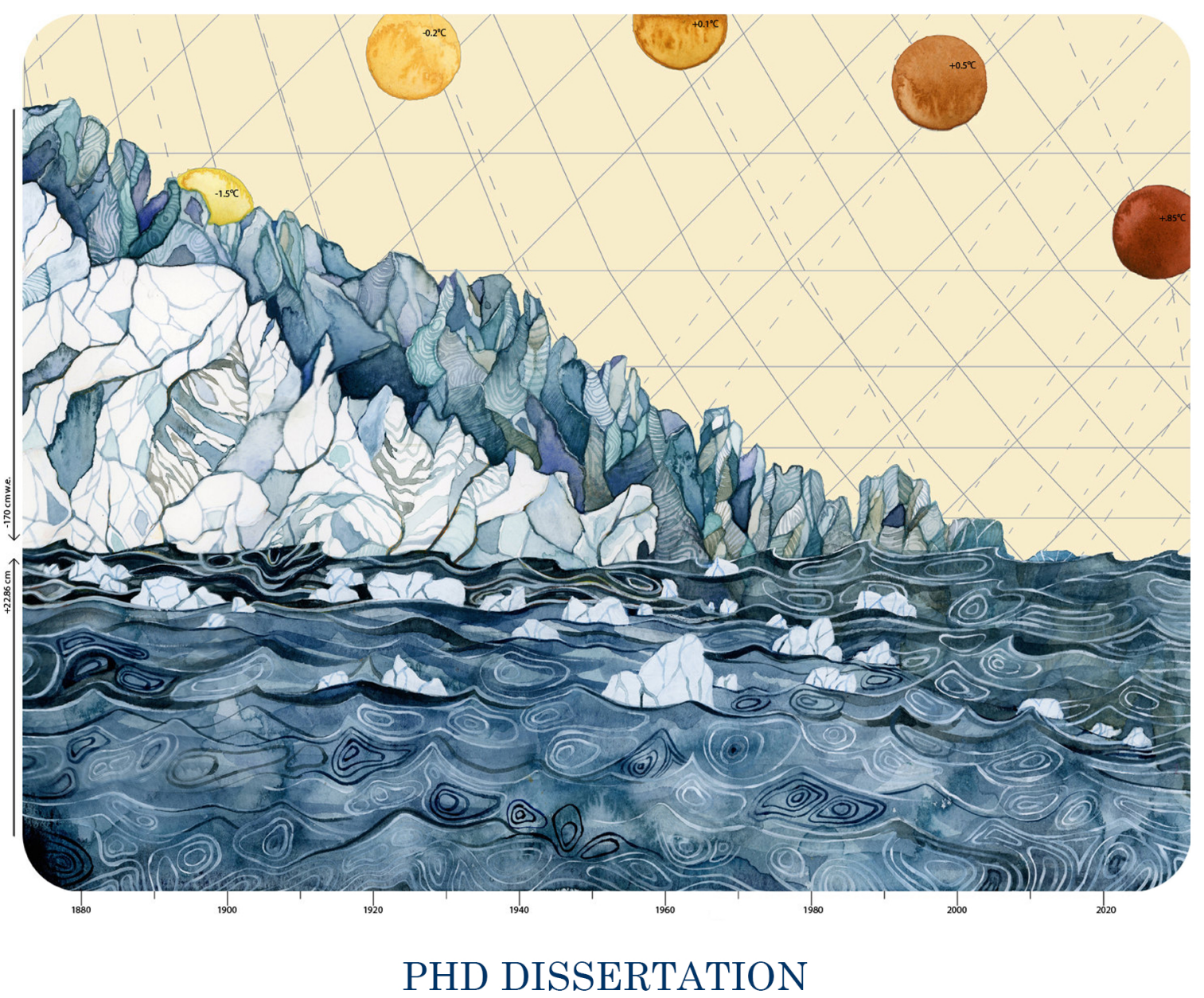

May 2017 

I think calling it climate change is rather limiting. I would rather call it the everything change.

Margaret Atwood

Everything great that ever happened in this world happened first in somebody's imagination.

Astrid Lindgren

You never change things by fighting the existing reality. To change something, build a new model that makes the existing model obsolete.

Richard Buckminster Fuller 



\section{CONTENTS}

LIST OF ARTICLES vii

ABSTRACT viii

DANSK SAMMENFATNING

ACKNOWLEDGEMENTS xiii

1

INTRODUCTION 14

1.1 Overall ambition, aim and focus 16

$\begin{array}{lll}1.2 & \text { Research questions } & 17\end{array}$

$\begin{array}{lll}1.3 & \text { Research process and articles } & 17\end{array}$

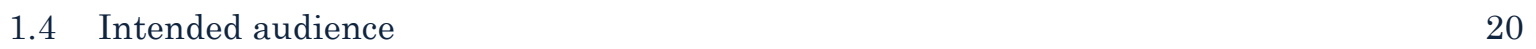

2

THE CHALLENGE OF TRANSFORMATION 21

2.1 Politics of transformation 22

2.2 Imagining transformation 24

3

CONCEPTS AND THEORETICAL CONSIDERATIONS 27

3.1 Governance 28

3.2 Institutional change in the governance of change 31

3.2.1 Conceptualizing institutions 32

3.2.2 Conceptualizing change $\quad 35$

3.3 Ideational in institutional analysis of public policy 39

3.3.1 Ideas matter in political and institutional analysis 41

3.3.2 Institutions as constituted through discourse 42

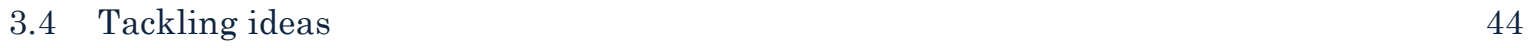

3.5 Concluding thoughts 46

4

ANALYTICAL FRAMEWORK $\quad 48$

4.1 Introducing discursive institutionalism 48

4.2 Power through ideas, in ideas and over ideas $\quad 52$

$\begin{array}{lll}4.3 & \text { Policy arrangement approach } & 56\end{array}$ 
METHODOLOGICAL APPROACHES 60

5.1 Ontological, epistemological and methodological considerations 61

5.2 Case-study research design $\quad 62$

$\begin{array}{lll}5.3 & \text { Data collection } & 65\end{array}$

$\begin{array}{ll}\text { 5.3.1 Policy analysis } & 68\end{array}$

$\begin{array}{ll}\text { 5.3.2 Interviews } & 68\end{array}$

5.3.3 Participant observation $\quad 73$

$\begin{array}{lll}5.4 & \text { Discourse analysis as a method } & 73\end{array}$

$\begin{array}{lll}5.5 & \text { Limitations and challenges } & 76\end{array}$

6

SUMMARY OF ARTICLES $\quad 79$

ARTICLE I. Conceptualisations of sustainability in carbon markets 79

ARTICLE II. Could baseline establishment be counterproductive for emissions reductions?

Insights from Vietnam's building sector $\quad 82$

ARTICLE III. Claiming, fixing and imitating transformation: the case of low-carbon

development policy arena in Vietnam $\quad 85$

ARTICLE IV. The politics of ideas in low-carbon infrastructure development:

transformational change and the governance of energy systems.

7

$\begin{array}{ll}\text { CONCLUDING REMARKS } & 91\end{array}$

$\begin{array}{lll}7.1 & \text { Answering research questions } & 91\end{array}$

7.1.1 The construction of meaning: ideas, discourses and storylines 92

7.1.2 The power of ideas 94

$\begin{array}{lll}7.2 & \text { Contribution } & 96\end{array}$

$\begin{array}{lll}7.3 & \text { Overall conclusion } & 96\end{array}$

8

POLICY RELEVANCE 100

REFERENCES 103

APPENDICIES $\quad 120$

APPENDIX I. INTERVIEW PROTOCOL 120

APPENDIX II. LIST OF RESPONDENTS (ANONYMISED) 124

APPENDIX III. ARTICLES $\quad 127$ 


\section{LIST OF ARTICLES}

This dissertation builds on the studies undertaken in the following four appended articles, which are referred to by their corresponding Roman numerals in the text:

ARTICLE I, lead author, published. Maryna Karavai and Miriam Hinostroza (2013): Conceptualisations of sustainability in carbon markets, Climate and Development, DOI:10.1080/17565529.2012.762332

ARTICLE II, lead author, published. Maryna Karavai, Søren E. Lütken and Daniel Puig (2017): Could baseline establishment be counterproductive for emissions reduction? Insights from Vietnam's building sector, Climate Policy, DOI:10.1080/14693062.2017.1304350

ARTICLE III, sole author, manuscript under review. Maryna Henrysson. Claiming, fixing and imitating transformation: the case of climate change mitigation policy arena in Vietnam.

ARTICLE IV, two authors contributed equally, advanced manuscript. Maryna Henrysson and Cary Yungmee Hendrickson. The politics of ideas in low-carbon infrastructure development: transformational change and the governance of energy systems.

Article I was co-authored by two contributors, with Henrysson as lead. Henrysson steered the writing process and was responsible for the research idea, data collection, analytical choice, data interpretation, the overall discussion and conclusions. Hinostroza contributed in the areas of her immediate expertise. The article is included in the dissertation with her permission.

Article II was written together by three authors, with Henrysson as lead. Henrysson steered the writing process and was responsible for the research idea, analytical choice and overall discussion and conclusions. Lütken and Puig contributed in the areas of their own expertise. The article is included in the dissertation with their permission.

Article IV is the result of equal collaboration between Hendrickson and Henrysson, who both collected and analysed the data for separate case studies, jointly made the analytical choices, interpreted the results and contributed to the discussion. 


\section{ABSTRACT}

Securing a low-carbon future will require a multitude of 'low-carbon transformations'. The issues are how such transformations are imagined and framed, along which pathways and who steers them, including the very basic question of what decisions are made to transform the present challenges to climate change governance. Understanding of the politics of these governance challenges is important in explaining which pathways are supported or delegitimised and which are ignored and fail to get off the ground.

This dissertation focuses on the role of institutions and ideas in the multilevel, multi-actor and multi-factor governance of climate-compatible development. It aims to improve our understanding of potential endogenous sources of transformation by asking how ideas of sustainability influence the governance of a low-carbon society. It investigates the construction of policy problems, the content of policy proposals and the political agenda of present policies and reform imperatives around climate change mitigation and lowcarbon development. The question is addressed using a combination of perspectives, including governance theory and the constructivist institutional approach.

Empirically, this dissertation is based on four separate case studies presented in individual articles. The study of voluntary carbon market mitigation projects in the Sub-Saharan region maps out the market actors and their conceptualisations of sustainability to highlight the ideas behind marketbased solutions to climate change mitigation. In examining national climate change mitigation and green growth strategies in Vietnam, it was demonstrated how the current institutional context relates to the background to long-term transformation and programmatic ideas about how to achieve it. In the study of baseline setting in developing Nationally Appropriate Mitigation Actions (NAMAs) in the building sector in Vietnam, the role of international knowledge practices in national policy-making was questioned. Finally, the examination of electricity infrastructure development showed how reforms to low-carbon energy systems are justified in two different sociotechnological settings: Mexico and Vietnam.

On the one hand, the findings indicated that over time, by invoking and appealing to arguments associated with the ideas and principles of 
neoliberalism climate change mitigation and low-carbon development, agendas have become more acceptable in the formation of sectoral policies. On the other hand, the analysis shows how policy experts and technocrats use their epistemic power and ideational abilities to limit the scope of debate, thus constraining the range of policy responses. When there are no fundamental transformational shifts in the background and in programmatic ideas about development, the actors that frame the institutional context within a prevailing framework further legitimise conservative ideas about climate governance. For instance, solutions normalising the temporal necessity of fossil fuels in electricity generation while justifying economic growth by means of green growth arguments become more deeply embedded in development trajectories. Narrow conceptualisations of policy problems and solutions in the cases presented here have resulted in incumbent actors resorting to quite conventional instruments of technological market-based fixes in the absence of alternative and/or more transformational visions of development.

Overall, this dissertation contributes to on-going debates over domestic politics and policy-making regarding 'green transformations' and adds to the emerging policy field in developing countries contexts. It argues that there is a need to stimulate critical reflection on the existing assumptions regarding mitigation actions. It argues that governance choices, for example, in electricity infrastructure development or energy efficiency in buildings, or a broader range of mitigation actions, are not only defined by technological lockins. Equally important is the persistence of ideas that are used to justify and legitimise reforms by mobilising discourses on energy supply and security and framing energy transitions as part of wider goals to maintain socio-economic stability and pursue green growth development strategies. This dissertation shows that low-carbon development should not only be technically, institutionally and economically feasible, but also politically and ideationally feasible, to translate into action. Measures for institutionalising long-term transformation are unlikely to be effective if ideas about transformation cannot be developed within the parameters set by governance regimes.

The key argument of this dissertation is that, for the governance of low-carbon societies, it is crucial to recognise that climate change mitigation actions are more than economic or technological challenges - they are politically charged. Paying attention to problem framings and to the diversity of multi-actor perspectives could facilitate novel responses to climate change and enable more inclusive forms of governance, as well as throwing light on the 
fundamental incompatibility between and limited reach of generalised policy solutions and technological fixes.

Key words: low-carbon development, climate change mitigation governance, discursive institutionalism, ideas, transformational change, socio-technical energy systems 


\section{DANSK SAMMENFATNING}

Sikring af en fremtid med minimal udledning af $\mathrm{CO}_{2}$ vil kræve en lang række transformationer. Hvordan sådanne transformationer forestilles, indrammes og styres herunder det meget grundlæggende spørgsmål om, hvad beslutningsgrundlaget er for at imødegå de nuværende klimaforandringer.

Denne afhandling fokuserer på institutionernes rolle i multi-level, multi-actor og multi-factor -"governance" af klimakompatibel udvikling. Den sigter mod at forbedre vores forståelse af potentielle transformationskilder ved at spørge, hvordan bæredygtighedens ideer styrer imod et samfund med minimal udledning af $\mathrm{CO}_{2}$. Afhandlingen undersøger af politiske problemer, indholdet af politiske forslag og den politiske dagsorden for de nuværende politikker og reformkravene omkring begrænsning af klimaforandringer. Spørgsmålet er rettet ud fra en kombination af perspektiver fra styringsteori og konstruktivistisk institutionel tilgang.

Empirisk er denne afhandling baseret på fire separate casestudier præsenteret i individuelle artikler. En kortlægning af frivillige CO2-offset projekter i regionen syd for Sahara og deres konceptualiseringer af bæredygtighed for at fremhæve ideerne bag de kommercielle løsninger til begrænsning af klimaændringerne er undersøgt. Ved at undersøge grønne vækststrategier i Vietnam blev det påvist, hvordan den nuværende institutionelle kontekst er linket til programmatiske ideer om, hvordan man opnår langsigtet transformation. I tilfælde af etableringen af baseline til udvikling af nationale klima projekter (NAMA'er) i byggesektoren i Vietnam blev spørgsmålet om international videnspraksis rolle i udvikling af nationale love undersøgt. Endelig præsenteres udviklingen af elektricitetsinfrastruktur, hvordan $\mathrm{CO}_{2}$ venlige energisystemsreformer viser sig at være berettiget inden for to forskellige socio-teknologiske rammer: Mexico og Vietnam.

På den ene side konstaterede resultaterne, at de over tid ved at påberåbe og appellerer til argumenter i forbindelse med neoliberalismens ideer og principper - såsom liberalisering af elektricitetssektoren, modernisering og grøn miljømæssig udvikling - begrænsning af klimaforandringer og $\mathrm{CO} 2$ venlig udvikling mere acceptabelt inden for sektorpolitikker. På den anden side viste analysen, hvordan politikeksperter og teknokrater bruger deres 
epistemiske magt og evner til at begrænse debattens omfang, hvilket begrænser omfanget af politiske reaktioner. Når der ikke er nogen grundlæggende transformationsskift i baggrunden og programmatiske ideer om udvikling, legitimerer aktører, der rammer den institutionelle kontekst inden for en rådende ramme, de konservative ideer i klimaforvaltningen yderligere. For eksempel bliver løsninger, der normaliserer nødvendigheden af fossile brændstoffer i el-produktion, samtidig med at den grønne vækst motiverer økonomisk vækst, dybere indlejret i udviklingssporerne. Konceptualisering af politiske problemer og løsninger i de fremlagte sager har resulteret i, at de etablerede aktører anvender ganske konventionelle instrumenter i den teknologiske markedsbaserede løsning i mangel af alternative og/eller mere transformative visioner om udvikling.

Samlet set bidrager denne afhandling til igangværende debatter om indenrigspolitik og politikformulering af "grønne transformationer" og tilføjer udviklingslandenes kontekst. Dette arbejde hævder, at der er behov for at stimulere en kritisk refleksion overfor eksisterende klimavenlige løsninger. Den hævder ydermere, at styringsvalg, f.eks. ved udvikling af el-infrastruktur eller energieffektivitet $\mathrm{i}$ bygninger eller af en bredere vifte af $\mathrm{CO}_{2}$ reducerende tiltag, ikke kun skal defineres ved teknologiske løsninger. Lige så vigtigt er vedholdenheden af ideer, der bruges til at retfærdiggøre og legitimere reformer ved at mobilisere diskurser om energiforsyning og sikkerhed som en del af bredere mål for at opretholde socioøkonomisk stabilitet og forfølge strategier for udvikling af grøn vækst. Denne afhandling illustrerer, at klimavenlig udvikling ikke kun skal være teknisk, institutionelt eller økonomisk gennemførlig, men også muligt politisk at omsætte til handling. Foranstaltninger til institutionalisering af langsigtet transformation vil næppe være effektive, hvis ideerne om transformation mangler evnen til at udfolde sig inden for de parametre, som styringsregimer fastsætter.

Key words: low-carbon development, climate change mitigation governance, discursive institutionalism, ideas, transformational change, socio-technical energy systems 


\section{ACKNOWLEDGEMENTS}

I would like to express my gratitude to all those who have assisted me in the preparation of this work, first and foremost, to Dr John M. Christensen and Dr Miriam L. Hinostroza for encouraging me to pursue this research in a first place. Dr Miriam L. Hinostroza, my lead supervisor, valued my academic independence, always reminding me that there was a bigger picture and believing that everything will work out. I also thank my co-supervisor, Dr Peter Newell, for his lasting interest in my work, timely and concise input and the inspiration I found in his work on the politics of climate.

Special mention goes to my brilliant co-authors Cary Yungmee Hendrickson, Dr Søren L. Lütken and Daniel Puig for doing so much more than coauthorship entails, and to Søren also for countless random conversations infused with optimistic scepticism. I also thank Cary for caring and carrying on as a relentless ally in an endless battle against words.

I greatly appreciate all those who gave their time and expertise during my field stay. In particular, I would like to thank the Danish Embassy in Vietnam, and the DEA and IFC experts, Jakob Jespersen and Poul E. Kristensen.

I would like to extend my thanks to Dr James Haselip for genuine and generous feedback on the article draft, and to my fellow students Dr Lea Ravnkilde Møller, Dr Mathilde Brix, Zyaad Boodoo and Dr Sandra Bry. Special thanks go to Frederik Staun, my long-lasting office mate, for his compassion and timely help, and to Dr Ksenia Petrichenko for an efficient introduction to the world of buildings. I am also grateful to Dr Anne Olhoff for her practical advice and to Pia Riis Kofoed-Hansen and Thomas Kragh Laursen for helping me on so many occasions.

Special thanks go to my dear friends Anna-Leena Raij, Lucille Rose TetleyBrown and Jean-Francoise Trinh Than for their love, kindness and helpful feedback.

Finally, but by no means least, I thank my little family, Jonas Tobias and Evald Maximilian Todar for bearing with me over the years of pulling a dissertation together. Thank you for your endless love. 


\section{1}

\section{INTRODUCTION}

The theme of this dissertation is the governance of climate stabilisation and low-carbon development. Although it examines the institutional context of climate change mitigation strategies, it is more a study of the politics of ideas in governing low-carbon transformation. The articles in this compilation draw on several case studies to emphasise the importance of both institutional contexts and discourses in shaping agendas of climate change mitigation and development.

If transformational change in socio-natural relationships is envisaged as a rapid transfiguration of the socio-economic model, a change that is fundamental, large-scale and just, such transformation requires paradigmatic changes in political responses, and above all in core ideas about paths of social development. An ambiguity inherent in the very rhetoric of agendas of future sustainability is perhaps one of the most intriguing dilemmas in the political space of climate change governance. A plethora of philosophies and actors participating in constructing climate change responses might make a shared mobilising narrative for change seemingly unimaginable. In my view, for the change in the governance of such politically contested issues as climate change to occur, a clear perspective on what constitutes the desired transformation is among the most basic conditions of change.

In engaging with theories of discursive institutionalism and looking at ideas as critical elements of meaningful change, the aim of the dissertation is to explore to what extent the political agenda of climate change mitigation and its governance is impacted by ideas about what constitutes long-term transformations and how to achieve them. It is an exploratory study into the role played by ideas about 'green transformation' politics and how they instigate change, perpetuate it or become a source of inertia. As such, this dissertation tests the applicability of ideational explanations of change. 
To achieve these aims, I adopt a multi-theory framework within the postpositivist constructivist tradition to aid in investigating of the role of the discursive construction of policy practice. I assume that analysis of the discursive performance of ideas about sustainability and development can provide insights into the contextual features of the institutionalisation of particular forms of governance. The findings of this inquiry may facilitate critical evaluation of the institutional context, enhance understanding of how ideas that are embedded in political choices and frame policy-making practices, and elucidate the role of a variety of actors in the adoption and translation of the low-carbon development agenda into policy practice.

First, the study identifies practices for governing climate change mitigation and low-carbon development and explores the rationales behind governance choices in the contexts of specific case studies. Secondly, by focusing on how and by whom policy solutions are envisaged, assembled and made meaningful, it investigates the institutional contexts of policy-making, paying attention to how institutions of governance are enabled by the ideational power around them.

The aim of this summary chapter for the compilation dissertation is to elaborate on the context, theoretical and methodological assumptions more thoroughly than is possible in the format of a journal article. Thus, in this chapter I will:

- Outline the overall ambition and goals of the study.

- Contextualise the research project.

- Introduce the assumptions of the study.

- Define the research questions.

- Discuss the potential of institutional and governance theory to answer the research questions; justify the choice of the theoretical and analytical frameworks; show how the theoretical explorations unfolded over the period of the research project.

- Elaborate on the methodological approach.

- Summarise the articles (I-IV) and discuss how they contribute individually to answering the overall research question.

- Present the overall conclusions of the research project by drawing together crosscutting findings from the case studies.

- Set out some of the findings and implications that are relevant to development practice. 


\section{Overall ambition, aim and focus}

A broad ambition of this work is to explore to what degree the political agenda of climate change mitigation is framed by ideas about what constitutes longterm transformation and how to achieve it. This implies looking at a multitude of perspectives in a variety of political and institutional circumstances, as well as examining how visions of low-carbon transformation are represented in policy-making practice and how actors influence the meaning systems of institutions.

The aim of this research is to enhance understanding of how ideas of sustainability and transformational change influence the governance of lowcarbon societies. This dissertation focuses on the role of institutions and ideas in the multi-level, multi-actor and multi-factor governance of climate stabilisation and low-carbon development. This research takes the form of an investigation into institutional structural and policy assumptions embedded in the construction of policy problems, the political agendas of present-day policies and the reform imperatives that have become prominent in the context of responses to climate change mitigation and reforms to the energy sector.

Employing an analytical framework based on constructivist institutionalism, I examine discursive interventions besides structural determinants. My analytical strategy is a combination of qualitative and interpretative methods. Empirically, this dissertation is based on four separate case studies presented in individual articles. The case of climate change mitigation and green growth strategies in Vietnam provides an example of how a new political agenda may be institutionalised on the level of national policy. It illustrates how the current institutional context relates to the background and programmatic ideas about achieving long-term transformation. I use the case of baseline setting in developing Nationally Appropriate Mitigation Actions (NAMAs) to reflect on the role of international discourses and to question the place of knowledge practices in national policy-making. In the case of voluntary carbon market I direct research attention to the actors and their conceptualisations of sustainability. The cases study aims to highlight the ideas behind markedbased solutions to climate change mitigation. Finally, the case of low-carbon electricity infrastructure development shows how ideas about low-carbon energy systems are envisaged, planned, assembled and made meaningful in two different socio-technological settings: Mexico and Vietnam. The analytical 
strategies and methods used are presented in each article separately and discussed in section four of this summary chapter.

\section{Research questions}

The articles that form this compilation dissertation address the considerations above from several conceptual perspectives. Altogether the contributions could be understood as being guided by a central research question:

How do ideas of what constitutes sustainability and transformational change influence the governance of a low-carbon society?

The following sub-questions support the main question. Although at first based on a literature review and preliminary interviews with key stakeholders, the sub-questions had been revisited and reshaped in line with the reflexive methodology approach (Alvesson and Sköldeberg 2000):

a) What are the ideas and discourses that have an impact on climate change mitigation governance and policy-making?

b) How are the ideas underlying political choices translated into the institutions and policy-making practices of climate change mitigation and low-carbon development in different contexts?

c) How and when do ideas about what constitutes sustainability, lowcarbon development and transformational change become influential in facilitating or impeding institutional change?

The findings in relation to these questions, which are brought together in an overarching claim in the introduction, are summarised in the concluding section. The contributions of the individual articles are outlined in the section five.

\section{Research process and articles}

The research questions have been addressed in four research articles referred to by Roman numerals in the text. An overview of these is provided in Table 1. The articles are presented in the chronological order in which they were submitted for publication in peer-reviewed journals. The sequence of articles 
reflects the reiterative research process that was adopted and the continuous process of modifying the analytical approach. The articles also complement each other in their analytical foci.

The format of a compilation dissertation imposes certain limitations. The duration of research and the iterative research design make it especially challenging to present it, to justify the analytical strategies and to demonstrate how the investigations of the various case studies contribute to answering the overarching research question. Therefore, a brief reflection is needed on the research process before proceeding further.

In a period of four years, the research questions and theoretical and analytical assumptions have been continually adjusted. I considered a range of theoretical approaches and analytical strategies when collecting and reviewing the empirical evidence. The availability of empirical material, however, considerably limited the ambitions of the analytical strategies. Empirically, the case studies were selected as relevant examples, first of policy and institutional development, but also of policy arenas that can demonstrate the interplay between actors, discourses and ideas in climate change mitigation, as well as testing the value of a discursive approach in institutional analysis in various contexts. The data for the Article I case study were collected in 2009 and revised in 2012, while the data for Articles II and III were collected during two field visits to Vietnam in 2013-2014. The data for the case studies in Article IV were collected and revised by both co-authors in 2015 and 2016. A number of other potential country-specific cases were considered prior to a final decision on the relevance of the cases.

What unites this work is nonetheless an assumption that governance of climate change mitigation is defined and influenced not only by materialistic factors, self-interest, power asymmetries or global regimes. This motivated me to investigate the issue within a broader institutional context. While working at UDP, I acquired first-hand experience with institutional development practice in developing countries. Due to the various limitations imposed on the practice of development work, I suggest that practitioners rarely look beyond institutional framework adjustment, only occasionally reflecting on the complex institutional environment and the nature of climate change politics in the countries they are examining. From a starting position as an employee of an organisation that assists countries in implementing the UNFCCC requirements, low-carbon development and climate change mitigation policies, 
I became curious about what it is that development practitioners are trying to change and what defines the change that is expected to happen.

\begin{tabular}{|c|c|c|c|c|c|c|}
\hline No & Author(s) & Title & RQs & $\begin{array}{l}\text { Scope of } \\
\text { Analysis }\end{array}$ & $\begin{array}{l}\text { Analytical } \\
\text { framework }\end{array}$ & $\begin{array}{l}\text { Geograph. } \\
\text { setting }\end{array}$ \\
\hline 1. & $\begin{array}{l}\text { Karavai M. and } \\
\text { Hinostroza M.L. }\end{array}$ & $\begin{array}{l}\text { Conceptualisations of } \\
\text { Sustainability in Carbon } \\
\text { Markets (published } 28 \\
\text { January 2013, Climate and } \\
\text { Development Journal). }\end{array}$ & a), b) & $\begin{array}{l}\text { VCM market } \\
\text { projects, cross- } \\
\text { country analysis }\end{array}$ & $\begin{array}{l}\text { Discourse } \\
\text { analysis } \\
\text { (Hajer). }\end{array}$ & $\begin{array}{l}\text { Sub- } \\
\text { Saharan } \\
\text { Africa }\end{array}$ \\
\hline 2. & $\begin{array}{l}\text { Karavai M., } \\
\text { Lütken S.E. and } \\
\text { D. Puig. }\end{array}$ & $\begin{array}{l}\text { Could baseline } \\
\text { establishment be } \\
\text { counterproductive for } \\
\text { emissions reductions? } \\
\text { Insights from Vietnam's } \\
\text { building sector (published } \\
10 \text { April 2017, Climate } \\
\text { Policy Journal). }\end{array}$ & $\begin{array}{l}\text { a), b) } \\
\text { and } \\
\text { c) }\end{array}$ & $\begin{array}{l}\text { National Sectoral } \\
\text { Policies }\end{array}$ & $\begin{array}{l}\text { Policy } \\
\text { arrangement } \\
\text { approach }\end{array}$ & Vietnam \\
\hline 3. & Henrysson M. & $\begin{array}{l}\text { Claiming, fixing and } \\
\text { imitating transformation: } \\
\text { the case of low-carbon } \\
\text { development policy arena } \\
\text { in Vietnam (under review). }\end{array}$ & $\begin{array}{l}\text { a), b) } \\
\text { and } \\
\text { c) }\end{array}$ & $\begin{array}{l}\text { National Climate } \\
\text { Change } \\
\text { Mitigation and } \\
\text { (low-carbon } \\
\text { development) } \\
\text { policy arena }\end{array}$ & $\begin{array}{l}\text { Discursive } \\
\text { institutionalism }\end{array}$ & Vietnam \\
\hline 4. & $\begin{array}{l}\text { Henrysson M. } \\
\text { and } \\
\text { Hendrickson } \\
\text { C.Y. }\end{array}$ & $\begin{array}{l}\text { The politics of ideas in low- } \\
\text { carbon infrastructure } \\
\text { development: } \\
\text { transformational change } \\
\text { and the governance of } \\
\text { energy systems (under } \\
\text { review). }\end{array}$ & $\begin{array}{l}\text { a), b) } \\
\text { and } \\
\text { c) }\end{array}$ & $\begin{array}{l}\text { Energy efficiency } \\
\text { infrastructure } \\
\text { projects, national } \\
\text { LCD political } \\
\text { economy }\end{array}$ & $\begin{array}{l}\text { Constructivist } \\
\text { institutionalism }\end{array}$ & $\begin{array}{l}\text { Mexico and } \\
\text { Vietnam }\end{array}$ \\
\hline
\end{tabular}

Table 1. List of Articles.

Following Article 1, where I look at how sustainability is defined by actors involved in offsetting projects in the voluntary carbon market (VCM), I considered empirical examples that include a wider range of actors and contexts. Meanwhile, I had an opportunity to obtain closer insights into processes surrounding low-carbon development strategies in Vietnam. While collecting data, I realised that, even though I had set out to investigate the institutional role of various actors in institutionalising the political agenda of climate change mitigation, I was in fact dealing with the ideational aspects of institutions. As a result, Article III focuses on the underlying values and norms of climate politics in order to identify institutional and political challenges. Another theme that became apparent is closely related to the 
academic debate on climate governance but is also an issue directly affecting the acceptance and application of policy mechanisms, namely the role of the experts and of knowledge and discourses in climate change governance. Looking at the NAMA process in the building sector in Vietnam in Article II, I questioned why, given the involvement of such a variety and number of actors and resources, the legislative and regulatory portfolio for the energy efficiency of buildings had been in development for more than a decade, yet its institutionalisation was failing. By looking at actors and their involvement in discourses in production, Articles II and III essentially look at the ideas and principles that guide the policy process and the politics of climate change mitigation.

\section{Intended audience}

This dissertation is situated in the discipline of political science. However, it also engages with global environmental governance research agenda and discussions in other fields that are concerned with the politics and practices of socio-economic, socio-technical and institutional transformation. My intention is that this work will provide insights into the institutional dimensions of practices in governing climate change mitigation and low-carbon development, as well as drawing attention to the importance of a more reflective approach in designing policy interventions. The intended audience for this research is thus a wider community of professionals in the domain of low-carbon development and climate change, namely researchers, public policy-makers, policy practitioners and capacity development practitioners. 


\section{2}

\section{THE CHALLENGE OF TRANSFORMATION}

The complexities and far-reaching consequences of climate change are a threat to both the biosphere and society. Academics, politicians, civil society and global climate financial institutions alike recognise that the extent and scale of the threat demands profound changes and calls for relations between society and nature to be reconceptualised. Unsurprisingly, desirable responses are increasingly perceived as requiring transformational changes to socioeconomic models of decarbonisation trajectories. Transformational change and paradigmatic shifts are seen as necessary if current and projected climate risks are to be managed, and they are regarded as the goal of policy interventions (Burch 2011; Kates et al. 2012; Edenhofer et al. 2014; Moore et al. 2014; Olsson et al. 2014; Stirling 2014; Gillard et al. 2016; Winkler and Dubash 2016). Redirecting development on to a sustainable course is envisaged to take place through a variety of means, such as a low-carbon industrial revolution (Stern and Rydge 2012), a green economy (UNEP 2011), a new climate economy (GCEC 2014), new forms of climate capitalism (Newell and Paterson 2010) and technological advances in energy systems, green growth or radical decarbonisation. Yet, the strategies for achieving profound change remain contentious, disregarding the insufficiency of incremental changes to modern socio-economic systems. While most scenarios accept that structural change is technologically possible, what to transform and how to do so remain endeavours that are contested both politically and socially. In practice, how systems transitions, for instance in electricity infrastructure or buildings, are taking place raises questions about the fundamental assumptions and governance principles that guide this process.

Much of the previous policy and academic debate has focused on the governance of transition (Scoones et al. 2015). Although there is a broad consensus among scholars on the importance of institutions in mainstreaming climate change agendas into development priorities, understanding the 
political and governance implications of the ideas underlying transformational change remains underexplored. Scholars have long emphasised that 'limiting emissions is not just a matter of technology and costs, but of culture, institutions and politics in the broadest sense' (Grubb et al. 1991: 911). Underlyinging ideas of climate governance determine who defines the endgoal of sustainability and development. The question then being what is to be transformed and who is to carry out and guide the transformation. Untangling political deviations, differences in economic reasoning and disagreements over short- and long-term visions of the developmental path are key to policy and institutional analysis, as well as development cooperation. Therefore understanding policy-making in a wider political context and advancing knowledge of how ideas (or change in ideas) shape governance institutions will enhance reflexivity in policy-making and build up the resilience of strategies aimed at transforming societal institutions (Hotimsky et al. 2006). This dissertation thus responds to the broader emerging agenda in the literature that is calling for more research into the domestic politics of climate change in developing countries (Tanner and Allouche 2011; Dodman and Mitlin 2015; Naess et al. 2015; Sovacool et al. 2015; Newell and H. Bulkeley 2016; Funder et al. 2017) and the emergence of new discourses of green transformation in the global South (Arnall et al. 2013; Death 2015).

In this work I seek to contribute to the debate on the internalisation of climate change responses and the expanding role of international actors first, by focusing on an issue that has received less attention in development research, namely the role of domestic institutions and national political contexts. Secondly, by engaging with political modes of thought and highlighting the underlining ideas, discourses and norms, I aim to shed light on the importance of constructing climate change as a problem for the politics of climate change.

\subsection{Politics of transformation}

The internationalisation of efforts to combat climate change is changing domestic institutions, policy-making practices, and policy implementation and outcomes. These changes are disputed, being framed by domestic political norms and institutions in an interactive process in which the international and domestic responses are mutually constitutive (Newell and Bumpus 2012; Newell et al. 2011). Examination of the policy processes, in order to comprehend the conditions for low-carbon transformations beyond the analysis of the capacity and effectiveness of institutional arrangements 
requires understanding complex multi-level country-specific and pathdependant policy processes. Research on the domestic politics of climate change mitigation and low-carbon development in developing countries has been expanding (Dubash et al. 2013; Newell and Bulkeley 2016). The particular focus of these debates is shifting from discussing low-carbon development in technical terms (such as technology transfer or financial mechanisms) towards discussing various aspects of the politics and political economy of climate change and green growth agendas (Lockwood 2013; Tanner and Allouche 2011; Tanner et al. 2014; Sovacool 2012; Sovacool et al. 2015; Death 2014). Indeed, the complexity of the governance of transformation requires reflection on which institutions, actors, institutional mechanisms and processes govern transformation, shape strategic responses and redefine the roles of domestic institutions (Paavola 2007; Vogler 2003; Lockwood 2015). It is argued that academic and policy debates around mainstreaming climate change mitigation into development agenda are of little value if they are not concerned with the wider political context in which they are being advanced (Lockwood 2013). Thus, understanding the politics is important in explaining which pathways are supported or delegitimised and which are ignored and fail to get off the ground (Scoones et al. 2015: 7). However, as yet the domestic political dimensions have not been sufficiently addressed in scholarship on socio-economic and socio-technical transformations (Smith et al. 2010; Meadowcroft 2011).

A diversity of visions about future sustainability are at the core of the debates around transformational change. How the transformation is imagined and framed, along which pathways, who steers it, who decides what to transform and what transformation is feasible are all detrimental in defining development pathways. Moreover, the incentives for political elites to endorse transformations, for the state to intervene and for business to provide the capital for transformation will depend on the political and economic contexts (Lockwood 2015). Another issue is that transformation on such a scale could easily be exploited to benefit one group at the expense of another, thus invoking questions about the political dimensions of transformation. Therefore long-term, large-scale, deliberate changes to socio-economic systems are politically contingent. The envisaged pathways are not politically or technically impartial, and policy framings and technological solutions have long-lasting consequences. It is not only the complexity of technological and policy solutions, the acceptance or rejection of scientific knowledge by the political elite, but also the capacity of actors' 'collective intentionality' (Ruggie 
1998) to articulate the relationship between the imagined socio-natural boundaries that define the possibility of change. This points to the influential political power of ideas and agency in shaping transformations.

\subsection{Imagining transformation}

Processes of transformation in the direction of a climate-compatible future are not limited to one geographical area or one particular policy, but involve multiple strategies that sometimes support and occasionally obstruct governance. Often the exercise of hard power is constrained in the context of highly fragmented policy arenas with a multitude of actors and institutions pursuing their interests. Consequently, actors may resort to coercive, discursive strategies. This implies that, in such contexts, ideational and discursive tools play a greater role in explanations of institutional change.

The discursive claims, ideational elements of problem definitions and knowledge framings that surround the politics of climate change and transformations are key in privileging particular actors and particular articulations of problems, as well as in endorsing certain solutions in the policy processes while disregarding others (Pettenger 2007: 236). As Feindt and Oels argue, 'struggles about concepts, knowledge and meaning are an essential element of the political process; and political discourse has material and power effects as well as being the effect of material practices and power relations' (2005: 161). Discursive framings of policy problems, background ideas and norms are crucial characteristics of policy domains, and 'neglecting these discursive structures leads to unduly optimistic and in fact rather technocratic thinking about policy change' (Hajer 1995: 275). Policy-making is an interpretative activity where different actors struggle over the meaning of a policy problem (Hajer 1995). Political actors ground their decisions in ideas about the relationship between the economics of climate change mitigation and the risks posed by climate change when determining economic and development policy (Darden 2009). What is often missing in policy-making practice, however, is an awareness of the importance of the guiding paradigm and the institutional context in shaping political responses and policy strategies.

Conceptualising change in terms of the 'transformative power of ideas' demonstrates the influence of ideas and discourses over political reality and shows how they instigate change or help to maintain continuity of change 
(Schmidt 2008). Opportunities necessitating institutional change do not arise only because of major social, environmental or economic crisis points, but in the comprehensions of actors as well (Béland 2016). Thinking about the politics of transformation as a power struggle in terms not only of its materialistic manifestations, but also of discursive and ideational contestations over meaning highlights how we collectively discuss and frame problems and how this affects policy responses. Thus, ideas and discourses are understood as particular forms of power and political processes that are different from, but also interrelated with, other institutions

The political-economic context, the interplay of institutions and actors at different levels of governance, their background ideas and their discursive contestations define a diversity of transformation scenarios that are imagined and pursued in various parts of the world. A stronger focus on the interrelationship between 'interests', 'institutions' and 'ideas' is key to grasping the political aspects of socio-technical and therefore socio-economic change (Meadowcroft 2011: 73). A failure to account for the role of the ideational capacities of institutions and actors to alter or preserve current socio-economic models means that governance of transformation risks being detached from the varied domestic political and institutional circumstances. Focusing attention on the discursive framings, construction of meaning and underlying ideas problematizes the construction of climate change and development, thus helping us understand the transformation of the political response (Pettenger 2007). Regardless of this rather obvious premise, the literature pays only limited attention to the impact of discursive and ideational structures in pathways towards governing climate compatible futures (ibid.).

In this dissertation I understand the politics of transformation as 'a struggle for power played out in significant part through arguments about the best story' (Fischer 2003: x). It is 'a struggle for discursive hegemony in which actors seek to secure support for their definition of reality' (Ockwell and Rydin 2006: 383). I look at political and institutional change from the perspective of changes brought about by ideas, discourses and discursive contestations. I argue that treating ideas and discourses as a form of political power underlying policy-making can provide explanations for the origins of transformational change and for how ideas about it define governance practices. Indeed, there is a need for further empirical analysis of how changes in ideas lead to significant political changes (Carstensen 2011). 


\section{3}

\section{CONCEPTS AND THEORETICAL CONSIDERATIONS}

The aims of this chapter are to present the concepts and lines of argument and analysis in this dissertation. Below I outline my approach to the term 'governance' and related concepts of 'institutions' and 'ideas'. Although there are many points of contact and overlaps between the concepts, a critical question for the project has been how to approach them and from what perspective to incorporate the issue of 'change'. Addressing these normative challenges requires a strategy that transcends disciplinary boundaries. Ultimately, this dissertation draws on theories from a large body of political science in order to guide the analysis. Thus, it engages with a broad spectrum of multidisciplinary literature.

The guiding research question enquires about the role of ideas in governance practices in relation to climate change mitigation and low-carbon development. The analytical framework borrows from the institutionalist tradition, since the dissertation concerns institutions, and from discursive approaches, since it focuses on constructs and systems of meaning. Theories of institutions and governance offer two approaches to the understanding of change. First, discursive institutionalism suggests ways of comprehending how actors and their coalitions make sense of ideas, and how discourse provides meaning to institutions and manifests itself in the programmatic aspects of policy. Secondly, it helps to uncover strategies and practices that are employed to shape policy arena. Finally, understanding the discursive dimensions of multi-actor governance provides insights into how governance is executed.

In this section, I justify my reading of the governance and institutional literature. I first discuss theoretical approaches in studying governance, institutions, institutional change and ideas. Afterwards, I outline my understanding of the relevant concepts used in the present project. This 
review of the debate, however, does not set out to cover the growing body of literature on governance for sustainability or on political and institutional change at all comprehensively. In the next section I outline the conceptual perspective on governance adopted in this dissertation.

\subsection{Governance}

Consideration of socio-economic transformation implicates the multiple levels of decision-making on which a multitude of actors co-produce, co-enact and cogovern (Newell 2012, Bumpus et al. 2014). The lack of attention that has been paid to the politics of transformation is particularly noteworthy given the long tradition in multiple disciplines of studying the broad role of institutions in development and governance (Rodrik 2004: Acemoglu et al. 2005; Oberthür 2006; Easterly 2008; Bierman 2012). Modern governance theory offers a conceptualisation of the relationship between the state and society that departs from the instrumental view of governing and adopts an integrativeconstitutive perspective (Blatter 2012). It recognises that the sources of governance that are conventionally attributed to one group of actors, such as formal state institutions, are changing, thus providing a starting point for understanding how central governments and other public and private actors design and implement policies on the international, national and local levels (Marks and Hooges 2004). The literature on governance provides valuable insights into how certain forms of governance are suited to addressing and managing complex socio-economic change. The analytical concept of governance helps make sense of institutional diversity by paying attention to the complexity of policy problems, such as transformations in the energy sector, which this dissertation deals with (Articles II and III). This is of value in investigating institutions and policy-making practices in relation to climate compatible development.

Since the transition from 'government' to 'governance' implies a change in governing, or modes of governing, institutions of public steering must be redefined and reinvented to coevolve with an institutional environment (Duit et al. 2010). Development and governance scholars have long debated the source of institutional change, whether it originates in top-down or bottom-up processes of governance (Easterly 2008). Some authors view changes in governance as indicating a weakened state (Rhodes 1997). Others highlight the importance of shifting roles, in which the state's constitutional power is altered towards facilitation and cooperative partnering (Kooiman 2003). While 
authority is relocated upwards, downwards or sideways (Rosenau 2002, Marks and Hooges 2004), governing becomes a shared responsibility of the state, market and civil society (Kooiman 2003; Pierre and Peters 2000; 2005; Bierman and Dingwerth 2004; Dingwerth and Pattberg 2006; Jessop 2011; Kern and Gilek 2015). While scholars dispute to what extent changes in governing affect 'the steering capacity of the state' (Lange et al. 2013: 407), the higher jurisdictions, that is, constitutionally superior states, are likely not only to steer but also to alter unilaterally the institutions of governance (Rhodes 2007). Even though some question the exercise of state authority (Conca 2005), the legislative and regulatory function of government and its institutions remains key. The state remains a central actor, especially with respect to legitimacy and accountability, since non-hierarchical governance is often embedded in hierarchical structures operating in a 'shadow of hierarchy' (Böerzel and Risse 2010: 113). As Meadowcroft et al. put it, we are 'stuck with states for the foreseeable future' (2005: 494). Therefore, while this dissertation recognises that contemporary forms of governance are no longer dominated by the nation state but are exercised by a variety of institutions and actors, it does not deny the role of the state, and indeed, in the case studies the analysis focuses on the role of traditional institutions in the context of multiactor governance (Articles II, III and IV). Article I looks at the implications of market-driven governance approaches to mitigation for sustainable development.

There is a continuing debate in political science around 'governance' and changing 'modes of governance' (Kooiman 2003; Kersbergen and Waarden 2004; Bulkeley 2005; Pierre and Peters 2005). In the abundance of definitions, a polyvalent, polycontextual and contested concept is applied inconsistently (Pierre and Peters 2005, Kohler-Koch and Rittberger 2006; Rhodes 2000). It is thus important to clarify the position adopted by this dissertation.

The term 'governing' is broadly understood as the 'means for authoritatively allocating resources and exercising control and coordination' (Rhodes 1996: 653), or alternatively as actions that 'guide, steer, control, or manage sectors or facets of societies' purposefully (Kooiman 1993: 2). In a loose sense, governance has been conceptualised as the 'steering and control of society and the economy through collective action that aims to achieve common goals' (Torfing et al. 2012: 2). It includes governing by state through the coordination of and cooperation among social and political actors, as well as self-governing mechanisms (Kooiman 2003). The general definition of governance implies 
'every mode of political steering involving public and private actors, including traditional modes of government and different types of steering from hierarchical imposition to sheer information measures' (Heritier 2002: 185). This interpretation emphasises how collective action is organised and conducted (Okereke and Bulkeley 2007). Narrower conceptualisations of governance imply only 'types of political steering in which non-hierarchical modes of guidance, such as persuasion and negotiation, are employed, and/or public and private actors are engaged in policy formulation' (Heritier 2002: 185). Various forms of governance can be conceptualised through the dimensions of politics, polity or policy, depending on what is emphasised (Treib et al. 2007):

i. As 'politics', it focuses on 'the actor constellation and power relation between political actors' or the 'relationship between state intervention and societal autonomy' (Treib et al. 2007: 5). This dimension represents the process of how (collective) actors translate different preferences into policy choices and different interests into unified action.

ii. As 'policy', governance is interpreted in broad terms as a means of 'authoritatively allocating resources and exercising control and coordination (Rhodes 1996: 653). The political steering and decisions made, coordinated and implemented in a society are reflected in policy (Heritier 2001: 2, Peters and Pierre 2005: 215, Jordan and Schout 2006).

iii. As 'polity', governance is viewed as an institutional arrangement, a structure, process or 'system of rules that shapes the actions of social actors' (Treib et al. 2007). A polity is the framework of formal and informal institutions that direct the behaviour of actors within a society (Keman 2006; Héritier 2002). The rational choice, historical and sociological institutionalist approaches relate to how the polity dimensions of governance are conceptualised, governance being conceived as a system of rules that shape actors' actions, while the discursive, ideational approach adopted by this dissertation is more relevant for exploring the 'politics' and 'policy' dimensions.

In this dissertation, governance is understood as being defined by three criteria. First, it can be defined by the source of authority, recognising the rising importance of non-state actors, though that of state actors and state institutions is not denied. In the second definition, practices of governing are 
viewed from the perspective of the degree of deviation from 'traditional' governing (hierarchical) to 'new' styles of governance (co-, market-, selfgovernance). In the third definition, governing is understood as characterised by the modes of governance practice (deliberative, non-inclusive, technobureaucratic). Making sense of institutional expressions of governance and being aware of where the institution is situated can aid understanding of which institutions affect the governance of transformation in particular contexts and how they do so. This justifies my study of the modes of governance that define the possibility of ideas of transformational change emerging and unfolding.

This dissertation explores the 'politics' dimension of governance by looking at processes of the adaption, appropriation and translation of ideas and discourses around climate change mitigation by a constellation of actors. Article II explores how the discursive framing of ideas of ecological modernisation and green growth are exploited by dominant coalitions of state and transnational actors, and how power over, through and in ideas arises in domestic climate politics. I adopt a conceptualisation of governance that sees it as the 'complex process through which a plurality of social and political actors with diverging interests interact in order to formulate, promote, and achieve common objectives by means of mobilizing, exchanging, and deploying a range of ideas, rules, and resources' (Torfing et al. 2012: 14). In the individual case studies, I examine the ideational processes that shape institutional arrangements and the assumptions that affect the construction of policy problems and the content of policy proposals, as well as influencing the political agenda of present policies and reform imperatives (Béland 2009; Parsons 2015; Béland 2016).

\subsection{Institutional change in the governance of change}

This section outlines the established approaches used in explaining institutional change in order to justify the choice of discursive institutionalism to construct a theoretical framework and guide the research project.

Even though the scale of the transformation required calls for a 'green revolution', scholars agree that the current model of organising the economy and modern institutions will define the context in which change will occur (Newell 2015: 84). To analyse only climate governance and transformational aspirations in a contemporary policy context is to dismiss the impact of earlier 
policy choices and the reinforcement mechanisms that have been established, as well as to ignore the wider political and economic contexts (Gillard 2016).

Recognising governance as a multi-actor process in which 'decision-making competencies are shared by actors at different levels rather than monopolised by national governments' (Hooghe and Marks 2001:3) implies dealing with institutional diversity as an outcome (Paavola 2007; Paavola et al. 2009). This reading of the governance literature captures how dependent governance is on the institutions and processes of institutional change. In emphasising the diverse nature of institutional practices and actors, it calls for analysis to be expanded to reflect the range of governing practices, for environmental governance to be reconceptualised and for the focus to be shifted on to institutional solutions (Paavola 2007).

\subsubsection{Conceptualising institutions}

Existing scholarship treats institutions and governance as closely related components of one conceptual complex. In the environmental governance domain, institutions have long been recognised as central to understanding and addressing environmental problems (Ostrom 2011; Ostrom 2005; Young 2008). The expansion of institutional analysis into the sphere of environmental governance requires an understanding of how governance institutions and processes of institutional change are interpreted.

Social scientists have long directed attention to the importance of institutions in shaping socio-economic and political affairs by turning to institutional explanations of complex problems in society (March and Olsen 1989; Jacoby 1990; North 1990; DiMaggio and Powell 1991; Thelen et al. 1992; Rutherford 1994; Hall and Taylor 1996; Eggertsson 1997; Hall and Soskice 2001; Pierson 2004; Hall and Thelen 2009; Lowndes and Roberts 2013). In political science, international relations and economics, institutional scholars credited institutions with affecting and shaping impacts and determining economic, political and social outcomes (North 1990; Weaver and Rockmann 1993; Hall 1997; Przeworski 2004; Rodrik, Subramanian, and Trebbi 2004, Mahoney and Thelen 2009, Schmidt 2008). A theoretical framework for the analysis of institutions developed by institutional scholars has largely focused on the establishment of political and economic institutions (North 1990; Ostrom 1990; Crawford and Ostrom 1995) and on how, in pursuit of their short-term 
interests, rational actors often stimulate technological innovation, economic efficiency and long-term economic growth.

Institutions, in various interpretations of the concept, have been discussed extensively in analyses of environmental change (O'Riordan and Jordan 1999; Young 2003; Arts and Leroy 2006; Andonova et al. 2009; Young 2012; Paavola 2007; Leroy and Arts 2011). Institutional perspectives have contributed to the study of socio-natural interactions, enhancing our understanding of the problems of common pool resources, environmental hazards, and risk and environmental management (Hotimsky et al. 2006). For instance, the scholarship on institutional economics informed a significant body of research on local common property arrangements and multilateral environmental agreements (North 1990; Ostrom 1986; Hanna et al. 1996; Loehman and Kilgour 1998; Young 2002; Dolšak and Ostrom 2003; Young 2008; Ostrom 2008a; Ostrom 2010; Ostrom 2011; Ostrom and Andersson 2002). Research on common-pool resources explaining the role of institutions in managing them and the incentives for cooperation (Ostrom 2008b) has demonstrated that global processes and institutions shape local outcomes (Agrawal et al. 2008). Ostrom's contribution as part of the 'new institutionalism' school of thought and her significant research on polycentric governance principles has established a basis for understanding multi-level systems of governance (Ostrom 2011; 2015). Research in global environmental politics has contributed to an understanding of multi-level and transnational institutional regimes and the incentives for cooperation in global environmental governance, domestic sources of environmental policy, the role of developing countries and the effectiveness of regimes (Mitchell 2006; Young 2008; Biermann et al. 2012). Problem-centred regime analysis has examined regimes in detail and provided empirical evidence for the necessity of global institutional responses to the governance of common-pool resources and the crucial role of institutions in it (Young 2002; Underdal and Young 2004; Biermann et al. 2009).

Different strains of 'institutionalisms' have been consistently evolving in the broader fields of economics and political science, explaining social phenomena from an institutional perspective. The largest body of literature distinguishes between individual schools of institutionalisms, including rational choice, historical and sociological institutionalisms (Hall and Taylor 1996; Hall 2010), and later discursive (Schmidt 2008) and critical institutionalisms (Cleaver and De Koning 2015). A middle-range theory of new institutionalism embraces 
aspects of governance that are wider than institutions of state or government. A common view in the 'new institutionalism' is that institutions 'systematically and predictably affect political outcomes' (Crepaz and Damron 2009: 458). The basic argument of institutional approaches is that institutions matter and that 'something about institutions...explains the decisions that governments make' (Peters 2005: 164). Depending on their ontological stands, institutionalists across disciplines have come up with different views on what this 'something' is. Institutions are widely understood as involving both formal and informal rules, including formal structures of government (such as bureaucracies and legislatures), but also informal societal structures (such as interest representation in policy formulation and implementation, and party systems) that influence policy-making (Lijphart 1999; Schmidt and Radaelli 2004; Peters 2005).

In rational choice institutionalism, institutions, by North's definition, provide the basic rules of the road in an economy, including formal systems such as constitutions, laws, taxation, insurance and market regulations, as well as informal norms of behaviour, such as habits, customs and ideologies as a response to dilemmas of collective choice and collective action (North 1990).

In historical institutionalism, institutions are the formal or informal routines, norms and conventions embedded in the organisational structure of a national political system. Streeck and Thelen define institutions as 'building-blocks of social order: they represent socially sanctioned, that is, collectively enforced expectations regarding the behaviour of specific categories of actors or to the performance of certain activities' (2005: 9). An institution, in this view, is not necessarily a formal organisation (cf. Jepperson 1991). At the most basic level, institutions are a structural feature of society that transcends individuals and shows stability over time. Institutions are understood as sets of regularised practices with rule-like qualities which structure political and economic action and outcomes according to a logic of historically based path dependence (Hall and Taylor 1996; Pierson 2000; Mahoney 2002).

In the discursive approach, institutions are constructions (not givens) of the codified systems of ideas and practices they sustain and are 'contingent (as the results of agents' thoughts, words, and actions)' (Schmidt 2008: 314). At the same time institutions are given (as the contexts within which agents think, speak and act) (ibid.) These institutions are therefore internal to the actors, serving both as structures that constrain them and as constructs they create 
and change. Institutions are treated not, as in the traditional new institutionalism approach, as 'the external rule-following structures' 'that serve primarily as constraints on actors, whether as rationalist incentives, historical paths, or cultural frames' (Schmidt 2008). In the discursive approach institutions are instead simultaneously constraining structures and enabling constructs of meaning. They are internal to 'sentient' (thinking and speaking) agents whose 'background ideational abilities' explain how they create and maintain institutions when at the same time their 'foreground discursive abilities', enable actors to communicate critically about these institutions, to change (or maintain) them (ibid.). From the discursive institutional perspective, institutions, as set of authorised and sanctioned rules, create expectations regarding viable political choices in a particular context (Kjær and Pedersen 2001; Lynggaard 2007: 294). Meanwhile, sentient agents construct and reproduce institutions by preserving or disputing existing systems of meaning and discursive structures. This points to the next issue in considering the origin of change in institutions.

\subsubsection{Conceptualising change}

As well as the concepts of governance and institutions, the processes that determine the possibility of societal change have been approached from various perspectives. A wealth of literature aims to contribute to the comprehension of the idea of transformational change for low-carbon society, questioning what is to be considered as such (Kates et al. 2012; Termeer et al. 2017; Moore et al. 2014), how to initiate and enact transformation, and how to approach it analytically (Olsson et al. 2014). Explanations of transformational change have relied on, among other things, the socio-technical systems framework (Geels 2004; Haxeltine et al. 2013), the multi-level perspective (MLP) (Geels 2011; Geels 2014) and strategic niche management (SNM) perspectives, emphasising system dynamics and deliberate transition management (Elzen et al. 2004; Raven et al. 2010), and the socio-ecological systems framework (Folke 2006; Hodbod and Adger 2014), which stresses the independence of the adaptive capacity of ecological and societal systems in responding to climate change. However, system perspectives do not pay explicit attention to the politics of change (Gillard et al. 2016).

Since I have already assumed here that institutions and ideas matter for political and socio-economic changes in societies, I turn to institutional theories for an explanation of the origins and sources of change. A number of 
middle-range theoretical approaches situated within the realm of new institutionalism seek to explain general policy change. Looking for the same answers, the varieties of new institutionalism explain institutional origins, continuities and changes distinctively (Hall and Taylor 1996; Clemens and Cook 1999; Thelen 1999; Dacin et al. 2002; Schmidt 2008, Micelotta et al. 2017). The rational choice, historical and sociological strains of new institutionalism have mainly focused on explaining the continuity of institutions based on rationalist interests, path-dependant histories and cultural framings (Schmidt 2015).

Various accounts of modern new institutionalism complement each other in explaining both stability and change (Koning 2016). Some historical institutionalist approaches attribute change to exogenous events, stressing how, as the outcomes of policy-making processes, institutions are resistant to change due to path-dependency and policy inertia that locks transition into the existing models (Pierson 2000). These authors emphasise the role of critical junctures or large-scale exogenous shocks that remove or ease the usual structural constraints on action (Mahoney and Thelen 2010: 7), leading yet again to stability (Schmidt 2008b; Streeck and Thelen 2005). The basic premise here is that historical events and processes determine the future range of possibilities for actors, as making such policy choices in the process of institutional formation or policy implementation will have a continuing and deterministic impact over the policy (Peters 2005). Institutions become locked into particular choices, making it increasingly hard to reverse these institutional choices over time (Pierson 2000). Other work in historical institutionalism focuses on the patterns and processes of gradual institutional change and challenges the earlier focus on institutional continuity and path dependency (Mahoney and Thelen 2010). The implication is that, in contrast to the punctuated equilibrium model of stability in between moments of radical exogenously induced change, institutional change can more regularly give rise to gradual change processes, which may nonetheless transform institutions (Thelen and Streek 2005). The tradition of historical institutionalism that favours the gradual change explanation proposes that changes in the distribution of power within coalitions facilitates incremental change (Mahoney and Thelen 2010). However, this is to neglect the role of ideas in the determination of interests that can facilitate change in the prevailing order (Widmaier 2015).

In the rational choice institutionalism tradition, there is a strong emphasis on 
the formal structures. In rational choice institutionalism, various actors with clearly defined interests negotiate with each other, using power, bargaining and coalition-building to define policies that seek to maximise benefits within their well-defined and fixed interests, while political institutions are seen as having more or less fixed incentive structures and order-subverting practices defined by the interests of actors (Campbell and Pedersen 2001). Most strains of institutionalism distinguish between radical change rooted in a shift in logic from one institutional model to another and incremental change taking the existing logic and institutional model further (Walgenbach and Meyer 2008: 88).

Institutional approaches to explaining change have comparable limitations: reductionism, a reliance on exogenous factors and an excessive emphasis on order and structure (Lieberman 2002: 697). The ability of these three institutionalist approaches to explain change is often static, attributing change to continuity through fixed preferences, path dependencies and cultural norms. Ideas are treated as a form of path dependency in which ideational continuity appears as a dominant feature of the trajectory of 'postcrisis institutions' (Pierson 2004: 39). The discursive institutionalist approach differs from the three 'older' new institutionalisms, which tend to explain institutional change exogenously, ascribing it to critical junctures, external events or crises, and thus leaving us with 'unthinking actors' (Schmidt 2008: 314). Hay and Schmidt suggest that an ideation turn is motivated by the inability of the other institutionalist approaches to explain the origins of change without attributing it to a major external shock or crisis (Hay 2006; Schmidt 2008; Gofas and Hay 2010). Schmidt (2008: 304) in particular argues that the turn to ideas undermines the basic premises of the older three new institutionalisms that institutions are in stable equilibrium, with fixed rationalist preferences in respect of rational-choice strain, self-reinforcing historical paths, like path-dependency in strains of historical institutionalism, or prevailing cultural norms and the logic of appropriateness, as in sociological institutionalism. For this reasons, Hay and Schmidt respectfully introduce frameworks that use ideational rationales to explain institutional change, while not denying the effect of external shocks and disturbances.

From this perspective, the most valuable insight of ideational institutionalism is that objective conditions are not enough to explain institutional change (Koning 2016) and that policy institutions are in large part embedded ideas that are subject to reinterpretation (Béland and Cox 2011; Somers and Block 
2005). The majority of discursive institutionalists share the assumption that assemblages of ideas communicated in public eventually becomes rule-based systems of concepts and frameworks of meaning (Lynggaard 2007). Political actors employ ideas to reduce the uncertainty about potential pathways, since 'before agents can institutionally respond to a crisis they must have some idea about what the crisis is and what caused it' (Blyth 2002: 36). Thus, ideas provide coalition-building resources, empower agents to contest existing institutions, can attract resources to build new ones and are important in coordinating agents' expectations (Blyth 2015). The study of ideas is essential to the comprehension (rather than explanation) of developments in public policy (Parsons 2015; Béland 2016). New ideas conveyed through discourse can facilitate public policy as solutions to policy problems, as well as institutional change by changing actors' definitions of policy problems, policy legacies and 'fit', thus having an impact on self-interest (Schmidt and Radaelli 2004: 188). In discursive institutionalism, actors are capable of bringing about endogenous change, in contrast to other new institutionalisms that ascribe change to exogenous critical junctures, events or crisis, thus leaving actors without sentient capabilities (Schmidt 2008: 314). Political change occurs when first, ideas become discourses, and second, discourses are institutionalised (Lynggaard 2007). More recently, adhering to the actorcentred argument, Carstensen and Schmidt (2016) have emphasised the ideational dimension of power in institutional change and introduced the concept of power to acquire new insights into the endogenous sources of crisis and change.

To some extent, a neoliberal institutional framework and insights from governance theory are able to explain what type of change turns into a change in politics and governance. However, in my interpretation it is the intricate interaction of ideas and interests, the nature of political and economic institutions in a given policy arena, and the path dependencies of the previous political choices and ideational capabilities of sentient actors that determine the opportunities and impediments for transformation. Yet, ascribing the power to define to one explanation exclusively limits our comprehension of the complex political process of national climate change mitigation. 


\subsection{Ideational turn in the institutional analysis of public policy}

Even though policy-makers accept that ideas affect policy outcomes, there is a need to show how in order to enhance our comprehension of policy-making and policy change (Parsons 2015). Customarily political science and international relations theory prefer explanations that consider material factors or selfinterests to be the principal causes of political outcomes. Ideas are viewed as strategic tools for rational political actors to mobilise support for their policy objectives, as well as constraints restricting which policy options are seen as feasible or even plausible (Rodrik 2004). Meanwhile the political processes are believed to be dominated by the power of 'vested interests' (Rodrik 2014). In early neoclassical institutionalism, ideas are ascribed a role in explaining why actors occasionally resolve problems of collective action necessary to build stabilising institutions and sometimes do not (North 1990). It is commonly believed that institutions are instruments for providing governance and that norms serve as a basis for both (Dimitrov 2005).

Since the 1990s, in reaction to materialist and rationalist approaches, a growing number of social scientists have returned to analysis of the role of ideas in politics and public policy, which had been overlooked outside political theory (Goldstein and Keohane 1993; Hall 1993; Campbell 2004; Skowronek 2006; Schmidt 2008; Schmidt 2010; Béland and Cox 2011; Gofas and Hay 2010; Baumgartner 2014; Béland 2016; Carstensen and Schmidt 2016). A crucial aspect of this 'ideational turn' (Blyth 2003) is the articulation of causal arguments about the impact of ideas and related factors (culture, discourse, frames) on political and policy change (Parsons 2002). Ideational scholars have provided new insights into the relationship between ideas and institutions in policy-making by exploring the origins of institutions and their impact on agenda-setting, policy discourse and framing processes (Lieberman 2002; Campbell 2004; Béland and Waddan 2012; Schmidt 2008; 2010; 2015). However, even though the constructivist approach has been criticised for ignoring material factors that constrain the possible range of political actions (Marsh 2009; Hay 2011), it does not reject the role of the materialist and rationalist or suggest that that the former has no impact of its own (Béland 2016). Usually, the contemporary literature on the role of ideas stresses the constructed nature of 'interests', a concept widely debated among ideational scholars (Blyth 2002; Parsons 2007; Marsh 2009; Hay 2011). Hay (2011) 
suggests treating self-interest itself as an idea, contributing to the argument that ideas shape institutions and that interests are guided by ideas.

In the discursive approach, public policies are considered not only as influenced by the discourses of particular groups of actors, but as 'shaped and supported by the institutional processes in which specific discursive practices are embedded, processes which can have a life of their own' (Fischer 2003: 45). Shifting attention from actors' interests to discourses has implications for the ways in which power is located in the systems of knowledge that define the natural state of the world, as well as for solutions to perceived problems (Barnett and Duvall 2005: 20-22).

Discourse theory, being constructivist in nature, demonstrates how actors and institutions in political spaces construct ideas and meanings. A number of scholars focus on ideas and how they manifest themselves through discourses while studying policy processes. Discourse analysis is applied widely in the field of environmental politics (Dryzek 1997; Hajer 1995; Bulkeley 2000; Sharp and Richardson, 2001; Szarka 2004; Feindt and Oels 2005; Bäckstrand and Lövbrand 2006, Lovell et al. 2009). Existing research shows that new problem framings (e.g., through emerging discourses and storylines) can trigger political change. Analysing the discursive framing of policy is a potentially fruitful approach to 'explore underlying interests or ideologies' and 'to identify textual mismatches that may later have strong implications for outcomes' (Molle 2008: 149). The discursive approach is useful here as it suggests that ideas and meanings, including those around representations of climate change mitigation, are continuously reconstructed from various positions of power and conceptualised in a discourse through the play of power and that they cannot be separated from power (Dingler 2005). Power is seen as productive and as capable of constructing 'truths', versions of reality that become ritualised in society (Foucault [1975] 1991:194). Constructivist accounts allow us to look at the issues surrounding climate change as produced and co-constructed within systems of governance and at policy problem framings and solutions as impacted by ideational power.

Before proceeding to how ideas are understood in this dissertation, I first need to clarify this relationship between institutions, ideas and discourses. Here I turn to the ideational explanation in the institutionalist approach to organise the study of governance, acknowledging the crucial role of institutions in defining the possibility of transformational change in society. Articles I, II and 
III utilises a discursive approach in the analysis. Article I focuses on actors and discursive frameworks of sustainability in carbon market projects, concentrating on ideas, knowledge and discourses, and showing how they matter for the institutionalisation of climate change mitigation agendas. Articles II, III and IV relate to the set of institutional literature developed under the umbrella of discursive institutionalism. Articles II and III point to the discursive manifestation of ideas about climate governance and the links between global and national discourses. Thus the discursive approach and the ideational focus are the key to answering the research questions that guide this dissertation.

\subsubsection{Ideas matter in political and institutional analysis}

In recent years, there has been an increase in the volume of work that takes ideas seriously and that focuses on the dynamics behind the concept (Schmidt 2008; Schmidt 2015; Arts and Buizer 2009; Phillips et al. 2004) Hay 2006. The majority of scholars interested in ideational analysis agree that the presence of new ideas could cause changes to policies and institutions (Cox 2001; Hay 2002; 2016, Schmidt 2008; 2010). They suggests that frameworks of ideas define not only how a policy problem is understood, but also the policy choices and institutional structures involved (Niemelä and Saarinen 2012).

The ideational approach has been applied to the analysis of politics, political behaviour and policy processes (Béland and Cox 2011; Campbell 2004; Lieberman 2002; Carstensen 2011). A view of ideas as relatively independent of interests and institutions has won a lot of advocates in the political science and international relationship disciplines (Fischer Hajer 1995; Blyth 1997; Hay 2001; Campbell 2002; Gillard et al. 2016). This approach places ideas and their discursive power at the centre of political affairs and institutional reforms. As Hay (2002: 194) puts it:

'Ideas often hold the key to unlock political dynamics - as change in policy is often preceded by changes in the ideas informing policy and as the ability to orchestrate shifts in societal preferences may play a crucial role in

quickening the pace, altering the trajectory or raising the stakes of institutional reform'. 
Likewise, Schmidt suggests that focusing on ideas aids understanding of the politics of change:

'... for the dynamics of change, we must be able to go beyond 'politics as usual, that is, beyond an understanding of the interplay of interests, institutions, and cultures that represent the background conditions to change, to explain how political actors create an interactive consensus for change' (Schmidt 2001: 249).

\subsubsection{Institutions as constituted through discourse}

The choice of policy instruments does not imply a goal-means rationality but is influenced by the political and ideational values of political actors and their conceptualisation of reality (Lauber and Schenner 2011). The focus on the discursive becomes important as it explains the choice of political instruments and institutional change through discursive interactions, which is particularly relevant for the interdependence of climate change mitigation and low-carbon development policy. As argued by Phillips et al. (2004), institutions are constituted through discourse, and rather than actions, it is the articulation of those actions that bring about institutional change.

Hajer's policy discourse analysis provides an approach to making sense of the present competing and overlapping discourses that are modifying specific policy arenas. To use distinct storylines to force their understanding of a policy problem on others, propose certain social positions and practices, voice criticisms of existing arrangements or communicate with others, actors form coalitions (Hajer 1993; 1995). According to Hajer (1995), discursive hegemony comprises the processes of discourse structuration and institutionalisation. A discourse can be viewed as hegemonic, if it is preeminent in thinking and translates into institutional arrangements. Thus, discourse institutionalisation occurs when a discourse is translated into, adopted by and materialised as institutions.

In discursive institutionalism, in the institutional context discourse is defined as 'whatever policy actors say to one another and to the public in their efforts to generate and legitimise a policy programme', that is, as the 'exchange of ideas' between actors (Schmidt 2002: 210). As such, discourse encompasses both a set of policy ideas and values and an interactive process of policy construction and communicationl (ibid.). Discourse for Schmidt is a 
communicative process of mediation among institutions and actors, not a structural foundation (Schmidt 2008; 2010). She distinguishes between 'coordinative discourse' among policy-makers and actors involved in the policy process (government officials, policy entrepreneurs and consultants, private sectors, etc.) that engage in creating, deliberating, arguing, bargaining and agreeing on policies (Schmidt 2008; 2015). The political sphere is characterised by a 'communicative discourse between political actors and the public engaged in presenting, deliberating, arguing over, contesting, and legitimating those policy ideas' (Schmidt 2002; Schmidt 2008; Fischer and Gottweis 2013). In his discursive approach to policy analysis, Hajer (1995) claims that policy-making is an interpretative activity, with actors struggling over the meaning of a policy problem. As a result, the articulation affects the ways in which solutions are imagined and designed. Hajer (1995: 49) asserts:

Discourses imply prohibitions since they make it impossible to raise certain questions or argue certain cases; they imply exclusionary systems because they only authorise certain people to participate in a discourse; they come with discursive forms of internal discipline through which a discursive order is maintained; and finally there are also certain rules regarding the conditions under which a discourse can be drawn upon.

Discourses, as structured sets of meanings and conveyers of ideas, are linked with actors' perceptions of reality and their normative and cognitive ideas of action. Therefore discourse always matters, and interests and institutions are not separate from it (Hajer 1995). Institutions are past discourses 'solidified', while interests are dependent on discursive positioning and institutions (ibid.). Once discourses have become hegemonic, they are adopted by dominant actors as shared meanings (Schmidt 2011) and are perpetuated by the exercise of power. They thus reflect and enact power relations, enabling 'certain descriptions of reality' and 'empower[ing] certain actors while marginalising others' (Bäckstrand and Lövbrand 2007: 125; Adger et al.: 683). This view links the structural elements of politics (discourses and institutions) with the ideas, interests and perceptions of actors and their coalitions. Varying the institutional context is important in understanding why certain types of actor are more influential in exercising their ideational and discursive power than others (Béland 2016). 


\subsection{Tackling ideas}

There is a vast political science scholarship addressing ideas from the perspectives of culture, ideas as expert knowledge, ideas as solutions to collective action problems and ideas as programmatic beliefs. Ideational theorising approaches ideas as operating on multiple levels, as the overarching paradigms or tools of the bricoleur (Hall 1993; Campbell 2004; Carstensen 2011; Berman 2012), assuming different levels of causality between ideas, interests and institutional changes. In the framework of discursive institutionalism, ideas are accepted in different forms such as 'narratives, frames, frames of reference, discursive fields of ideas, argumentative practices, storytelling and collective memories' (Schmidt 2012: 86). Customarily the literature treats institutions and norms or ideas as overlapping parts of one conceptual whole, while the relationship among them is often assumed but not analytically settled' (Dimitrov 2005: 20). Even though ideas are separate, they are closely connected with other institutional forms, actors, rules and structures. Institutions, both global and local, are grounded in ideas and values, norms and principles. Structures are conceptualised in ideational terms, in respect of norms and background philosophies, and are based on 'collective intentionality' rather than individual beliefs (Ruggie 1998). Adopting the understanding provided in the discursive institutionalism framework, I assume that institutional change or continuity depends on the power of ideas, that is, on the capacities of political actors to promote ideas at the expense of the ideas of other actors (Carstensen and Schmidt 2016:2). Therefore, ideas need to be tackled above all in their relationship to power.

Ideas are distinguishable from institutions. Béland and Cox elaborate on this distinction by arguing that '[as] ideas give rise to peoples' actions, and as those actions form routines, the results are social institutions' (2011: 9). Ideas do not emerge out of a void, and an expansion of ideas and actors is needed to come to new institutionalisation processes. Ideas are held by individuals or adopted by institutions (Emmerij et al. 2005: 214). Therefore, 'ideas and institutions are symbiotic and cannot exist separately' (den Besten et al. 2014: 4). Ideas may potentially form institutions, and the relationship between ideas and institutions is thus seen as dynamic and mutually constitutive (Campbell 2004), both acting as restricting structures and enabling constructs (Schmidt 2011). Ideas might have different forms, such as 'narratives, frames, frames of reference, discursive fields of ideas, argumentative practices, storytelling, and 
collective memories, and change at different rates, either incrementally or in revolutionary shifts' (Schmidt 2011: 2).

Discursive institutionalism emphasises the 'logic-of-communication' (Schmidt 2008: 304), and, instead of analysing actors' perceptions, it is concerned with how ideas are constructed and communicated, focusing on the interactive process of discourse and actors' abilities within discourses in policy and political space (Schmidt 2012; Carstensen and Schmidt 2016). The framework addresses the 'structure-agent' nexus and recognises the role of persistent ideas in shaping policy interests and the power and ability of sentient actors to employ discursive practises to maintain or adjust structures.

In discursive institutionalism, ideas, as opposed to institutions, are seen as dynamic in the sense that they are not stable and delimited entities, but subject to change as they consider, redefine and are connected with other ideas. Simultaneously, as Carstensen (2011) has pointed out, ideas also change the context in which they emerge, potentially causing institutional change. Here I borrow from Carstensens' definition of political ideas as 'a web of related elements of meaning' (2011) that are represented through discursive manifestations. I am also inspired by a widely cited approach to ideas as policy paradigms established by Hall (1993), which treats ides as a framework 'that specifies not only the goals of policy and the kind of instruments that can be used to attain them, but also the very nature of the problems they are meant to be addressing' (ibid.: 279). This conceptualisation corresponds to an argument in the discursive institutionalism framework suggesting that the background ideational abilities of political actors serve as an interpretive framework that assigns values and makes interests actionable.

In line with the work of Schmidt (2001: 249) on ideational understandings of institutional change, I distinguish between the substantive content of ideas (e.g., through the storyline concept, which is also that utilised by Hajer) and discourses as interactive processes through which fundamental and programmatic ideas are conveyed (Carstensen and Schmidt 2016). Broadly, Schmidt (2008: 306-8) contrasts two types of ideas - principled beliefs regarding 'what's right' that 'attach values to political action and serve to legitimate the policies in a program through reference to their appropriateness'; and causal beliefs with reference to 'what works' and "provide the recipes, guidelines and maps for political action and serve to justify policies and programs by speaking to their interest-based logic and 
necessity'. In section three, I elaborate on the typology of ideas following Schmidt's differentiation between background, programmatic and policy ideas (2008, 2010). Traditional and more established institutionalist theories, by contrast, have a more static understanding of institutions, with limited explanations of origins and processes of subverting the prevailing order (Fischer 2003; Hope and Raudla 2012; Schmidt and Radaelli 2004).

There have been many attempts to classify ideational processes and levels of ideas while examining their impact on policy and wider societal change. In the individual cases studies in this work, I pay attention to three processes: (i) the construction of policy problems; (ii) the framing of policy alternatives; and (iii) the political conceptualisation of present policies and reform imperatives (Béland 2009).

\subsection{Concluding thoughts}

Regardless of ideational approaches in policy-making analysis ascribing more value to change and agency, they do not constitute a sufficient self-standing theory explaining occurrences of political change. Nonetheless they reveal how ideational processes construct problems and agendas in the policy arena, define the assumptions of policy objectives and instruments, and show how they are appropriated and used by actors as discursive tools to create a consensus for change (Schmidt 2001; Béland 2016). A focus on ideas is the key to the analysis of transformation. Understanding political institutions as embedded ideas, meaning structures and constructs (Schmidt 2010: 5; Béland and Cox 2011), policy as political ideas adopted by actors based on their conceptualisation of reality, interests as rooted in ideas and change as derived from the 'transformative power of ideas', this dissertation focuses on ideas in public policy as the key to transformational change. Ideas are conceptualised here as 'a web of related elements of meaning' (Carstensen 2011), and as represented through discursive manifestations (Schmidt 2010).

Discourses as interpretative schemes, ranging from formal policy concepts and texts to popular narratives and story lines that give meaning to a policy issue and domain (Dryzek 1997, Fischer 2003, Giddens 1984), can shape institutional design and contribute to institutional complexity and fragmentation. Discourse analysis has the capacity to reveal the role of ideas in politics and the embeddedness of language in practice (Hajer and Versteeg 
2005: 176). While discourse analysis is highly useful in analysing this aspect of institutional complexity, traditional discourse analysis can all too easily point at 'policy change'. Thus it can benefit from be complemented by an institutionalist approach, such as that of discursive institutionalism.

Therefore, I see potential in applying insights from institutional scholarship to explaining change in climate change governance and policy-making, as well as processes of transformational change. In the case studies, the empirical material is analysed from the perspective of a discourse analytical approach and the theoretical perspective of discursive institutionalism. 


\section{4}

\section{ANALYTICAL FRAMEWORK}

The analytical framework I employ in this dissertation shares the normative orientation of discursive institutionalism and applies it to a study of climate change mitigation politics in various contexts illustrated by a number of case studies. In this respect, it responds to one of the challenges in the global environmental politics research area, namely how to understand and examine the institutional design of environmental policies and the institutional aspects of governance, as well as the influence that ideas and discourses exert over climate change agendas.

In this chapter, discursive institutionalism is discussed as a theoretical starting point and a guide to the analysis. A description of the analytical framework inspired by the theoretical concepts of discursive institutionalism follows.

\subsection{Introducing discursive institutionalism}

The challenge for the choice of an analytical framework and a strategy with which to address the research problem in this dissertation is that institutions, particularly formal institutions, are more readily observable than interests and ideas in the policy arena. Moreover, empirical explorations of the importance of ideas in institutional change, or when discourse about ideas matters for policy processes, will inevitably centre around the ability of actors to engage with socially constructed ideas about institutions. In this dissertation, I highlight the significance of both formal institutions and political ideas in choosing policy instruments and approaches to governance. I have turned to the concepts of discursive institutionalism because they provide a useful conceptual framework within those social science approaches that focus on ideas and discourses in institutional analysis (Schmidt 2008; 2010) to explain how ideas foster change in the aims of governance approaches and institutions. 
Under the umbrella of discursive institutionalism scholars, pay explicit attention to ideas and processes through which actors deliberate over and devise new policy ideas (Schmidt 2008). While still being aware of the roles of rules and norms and the explanations provided by classic institutional theories, discursive institutionalism seeks to establish when ideas matter and when they do not for the initiation of institutional change. The ideational approach in institutionalism is not a well-defined theory, but a mixture of perspectives united by an emphasis on ideas as having intrinsic importance in policy-making and action. Throughout this project I use the term 'discursive institutionalism' when referring to the developments of discursive institutional approaches.

Discursive institutionalism focuses mainly on the role of discourses in politics. Discourses can mean either discursive processes by which ideas are expressed or the ideas that actors express (Schmidt 2008). Discourses enable actors to think, speak and act about or within institutions, and hence to change, maintain or create them, even while these actors are acting within existing institutions (Hall and Taylor 1996). Compared with the other theoretical perspectives within social sciences that study institutions, discursive institutionalism emphasises the key roles of discourses first, in influencing actors' preferences, interests and behaviour (Hajer 1995), and secondly, in maintaining institutional stability, while at the same triggering and legitimizing institutional change (Scott 2001). Discursive institutionalism places actors, their interactions and the ideas they ascribe to in the centre of the analysis. The institutional context in which and through which ideas are communicated via discourse and institutions has an important influence over interactions between actors (i.e. as the context in which actors speak, think and act and thus over how certain ideas are discussed. This is key to understanding 'how ideas are generated among policy actors and diffused to the public by political actors through discourse' (Schmidt 2011: 55). Institutions constitute the setting in which 'sentient' agents are the agents who convey their ideas through discourse and translate them into action (Schmidt 2008; 2010). Here the institutional context becomes the context of meaning where ideas and discourses are justified (Schmidt 2010). Institutions 'exist only in and through practices' and are manifested as analytical concepts that 'help us to make sense of such practices' (Hay 2016: 523). The struggle to change an institutional arrangement thus becomes a 'battle of ideas' (Schmidt 2008: 305) fought by individual and collective actors. Looking at the content of change over time explains why certain ideas or discourses for action are less 
likely to stimulate political action than other incremental changes, as the change depends on the level of ideas (background, philosophical or programmatic). The deep philosophical underpinnings of political actions and the social order are less likely to change rapidly than ideas in particular policy fields. Referring to the power in the background of ideas, Carstensen and Schmidt (2016) argue that as ideas might become embedded in structure, they exist 'at a deeper level than policy ideas... and are often left unarticulated as background knowledge', thus limiting the 'policy options [political actors] themselves believe to be normatively acceptable'. Intrinsically one set of ideas becomes superior to other, dominant conceptions of what is appropriate, stressing the logic that there is no alternative in governing action (Matthijs 2015).

Focusing on the momentum of change for policy in programmatic or philosophical ideas, whether at critical junctures or incrementally, the approach examines who translates ideas, by what means, in what spaces and how, while not disregarding the structural frameworks of power and the positions in which agents act (Schmidt 2015). These points in time and the content of transformational ideas or 'paradigm shifts' that are to become the basis for future ideational and discursive constructs and institutional meaning are the subject of analysis. Discursive institutionalism tends to pay more attention to the cognitive frames of agencies than to their material interests. It is rather a dynamic, agent-centred approach than focused on static and path-dependent patterns or on examining the processes of norm setting (Hall and Taylor 1996; Schmidt 2008.). It situates agency in the discursive interactions of sentient agents 'who construct, articulate, ate, argue, and contest ideas and arguments through discourse' in institutions (Schmidt 2012: 87).

With regard to the other institutionalisms, moreover, the discursive approach helps to explain the preferences and strategies of actors, as well as changes in normative orientations. Discourses are shared and contested ideas about the material that are reflected in communication (policy texts, political speeches, popular narratives, etc.). The ideas and actions of agents gain meaning and communicative power only in 'the formalised as well as informal institutions that inform their ideas, arguments, and discursive interactions' (Schmidt 2012: 106). Institutions are materialised ideas present in formal and informal arrangements and practices (laws, rules, values, norms, strategies, standards, procedures, etc., both practiced and codified) (Cleaver 2002; Schmidt 2008). 
Hence agency is exercised by means of discursive representations.

Discursive institutionalism assumes that the interests of actors are not fixed, but determined and changed by causal and normative ideas. Schmidt (2012) characterises agents mainly by referring to their abilities within discourses and distinguishes between 'background ideational abilities' and 'foreground discursive abilities' (Schmidt 2008). The former are 'human capacities, dispositions and know-how related to how the world works and how to cope with the world' that are 'internal to agents' (Schmidt 2012: 92-93). The latter constitute 'people's ability to think and argue outside the institutions in which they continue to act, to talk about such institutions in a critical way, to communicate and deliberate about them, to persuade themselves as well as others to change their minds about their institutions' (ibid.: 93).

In the words of Schmidt (2009), 'the ontology of discursive institutionalism, in sum, combines the "background ideational abilities," which answer the questions, "how are institutions created and how do they persist?" with the "foreground discursive abilities," which answer the question, "why do they change (or continue)?" (ibid.: 95). Schmidt's work on discursive institutionalism is aimed at demonstrating empirically the causal influence of ideas as explanatory of policy and institutional change (Schmidt 2006). Schmidt and Radaelli argue that:

'our emphasis on discourse is compatible with different epistemological approaches to the study of the policy process, along a continuum from positivist approaches in which ideas may be mainly seen as reflecting the strategic interests of actors to constructivist approaches in which ideas are seen to constitute interests' (2004: 194).

Discursive institutionalism as introduced by Schmidt (2008; 2010; 2012) does not provide concrete suggestions as to how it can be applied empirically. It is criticised for being overly deterministic, focusing on ideas and discourse to the exclusion of issues of power and position, and over-determining the role of ideas and discourse by forgetting that historical institutions and cultural frames affect the ways in which ideas are expressed and discourse conveyed (Bell 2011). Discourses are constrained by existing institutions, which determine what can be said meaningfully (Hajer 1995). According to Schmidt, policy and institutional reforms are only possible if actors within a political institutional system are able to develop distinct communicative and 
coordinative discourses to facilitate meaningful action within institutions (Blyth et al. 2016). As such, if the institutions and actors cannot communicate and coordinate the ideas, the institutional change cannot be attributed to static ideational structures. Schmidt suggests attributing institutional change to ideational change with caution. She implies (2006:113) that discursive institutionalism may not be able to stand alone as an analytical framework, as 'it is rather voluntaristic unless the structural constraints offered by the other new institutionalisms are included'. Nonetheless this does not undermine the value of a discursive approach in explaining political change.

In sum, from the perspective of discursive institutionalism adopted in his dissertation, agency instigates institutional change, and power relations have an impact on this change, whereas the ideas foster the aims of change. The approach used in this dissertation does not deny the role of interests or institutions in shaping ideas. Here my presumption is that discursive institutionalism has a greater potential than all other approaches in the "new institutionalism' to explain stability and change in institutional dynamics. In complementary fashion, the concepts of multi-actor governance allow for an understanding of the interactions between policy arrangements at multiple levels (supranational, national, sub-national, regional and local) and among a variety of actors. In the next section I outline how the perception of power adopted from the theoretical framework is utilised in Article II to explain the potential of transformational change and the roles of actors in defining institutions and institutional change.

\subsection{Power through ideas, in ideas and over ideas}

A central argument of the discursive institutionalism framework is that the combination of background ideational abilities (the substantive content of ideas) with foreground discursive abilities (the ability to think and argue outside the institutions) enables the interactive discursive practices (Schmidt $2011 ; 2012)$ that actors use to construct institutions, including public policies or political institutions (Béland 2009). This argument links ideas to practices of power.

'Ideational power is the capacity of actors [and actors' coalitions] to influence actor's normative and cognitive beliefs' (Carstensen and Schmidt 2016: 4). The conceptualisation of change as derived from the 'transformative power of ideas' adds an alternative perspective, in addition to explanations from 
structural and material interests, to investigate how change can be instigated or continuity maintained in political reality by the power inherent in the ideational and the discursive. According to Schmidt, discursive power comes from 'the ability of sentient agents with persuasive ideas to use discourse effectively, whether to build a discursive coalition for reform against entrenched interests in the coordinative policy sphere or to inform and orientate the public in the communicative sphere' (Schmidt 2009: 533). Ideas and discourse cannot be considered to the exclusion of power (Schmidt 2010: 18). As she puts it, public choices result not only from the clash of power among interests, 'but also from the battle of ideas through discourse and deliberation' (Schmidt 2009: 541). This understanding of change in background ideas as reflected in policy change is useful in understanding how the background ideas of what constitutes sustainability or transformation towards sustainability affect approaches to its governance. In discursive institutionalism, power does not depend on position, and 'objective interests' are not distinct from 'subjective ideas' about interests (Schmidt 2010: 7). Essentially the constructivist approach differs from the realist approach in interpreting the relationship between material interest and power, in which power is not understood as a result or manifestation of material resources or the capacity to act according to a set of material interests (Hay 2016). As such, it sees 'actors' interests and normative orientations as socially constructed rather than materially given', such that an ability 'to project inter-subjectively one's subjective interpretation of context' defines political power (ibid.: 533). In the discursive institutionalist approach, public choices are result 'also from the battle of ideas through discourses and deliberation' (Schmidt 2010: 18), and not only from the power dynamics among the actors.

Article III is concerned with the issue of power in the political process of institutionalising ${ }^{1}$ transformational change in relation to climate change mitigation policy in Vietnam. Adopting a constructivist approach in an institutional study, it sets out to test a postulate of discursive institutionalism, namely that, while public philosophies and programmatic ideas that are influenced by the existing structures and materialist interest of political actors can restrain political action, they can also provide the means to

\footnotetext{
${ }^{1}$ For (Leroy and Arts 2006: 10), 'applied to politics and policy processes, our concept of institutionalisation refers to the gradual stabilisation of definitions of problems and approaches, of strategies and solutions in and around specific policy domains. It also refers to the more or less fixed patterns of divisions of tasks and interactions that develop between the actors involved, to the stabilisation of more or less fixed rules of the game etc.'
} 
advance larger political goals (Campbell and Pedersen 2001; Schmidt 2008). The article uses analytical components of discursive institutionalism to establish a framework that integrates institutions, ideas and discourses by focusing on the issue of ideational power and its execution by political actors. The approach distinguishes three levels of ideas in relation to how power is executed: philosophy (as values), program (assumptions and principles) and policy (targeted solutions) (Schmidt 2008: 8). To test the usefulness of Carstensen and Schmidt's classification of ideational power in examining stages in political and policy developments, I investigate how ideational power is exercised through the persuasion to conform to particular views or norms, 'of what to think and do through the use of ideational elements' (power through ideas); the imposition of ideas and the exclusion of alternatives (power over ideas); and the institutional and structural constraints on assemblages of subject positions and ideas agents may take into consideration (power in ideas) (Carstensen and Schmidt 2016). I have applied this approach to a case study in Article III. The conceptual framework guiding the case study is presented in Table 2

\begin{tabular}{|c|c|c|c|}
\hline Concepts & $\begin{array}{l}\text { Classifica } \\
\text { tion }\end{array}$ & Interpretation & $\begin{array}{l}\text { Examples in } \\
\text { the policy } \\
\text { arena }\end{array}$ \\
\hline \multicolumn{4}{|l|}{ Ideas } \\
\hline & \multirow[t]{3}{*}{ Level } & $\begin{array}{l}\text { Background-unquestioned assumptions of a polity, the deep } \\
\text { philosophical approaches that serve to guide action, the } \\
\text { unconscious frames or lenses through which people see the } \\
\text { world, and/or the meaning constellations by which people } \\
\text { make sense of the world. }\end{array}$ & $\begin{array}{l}\text { The association of } \\
\text { ideas of state/party } \\
\text { ideology and } \\
\text { sustainable } \\
\text { development; } \\
\text { market-led } \\
\text { governing. }\end{array}$ \\
\hline & & $\begin{array}{l}\text { Programmatic-assumptions and organising principles that } \\
\text { define the problem and its solutions. }\end{array}$ & $\begin{array}{l}\text { National strategies } \\
\text { regarding } \\
\text { sustainable } \\
\text { development, climate } \\
\text { change mitigation, } \\
\text { green growth. }\end{array}$ \\
\hline & & $\begin{array}{l}\text { Policy—particular decisions, solutions or a set of decisions or } \\
\text { solutions to serve a specified course of action. }\end{array}$ & $\begin{array}{l}\text { Electricity pricing } \\
\text { policy. }\end{array}$ \\
\hline & Type & $\begin{array}{l}\text { Normative-connect the three levels by referring to values } \\
\text { and appropriateness. Defined as ideas about appropriate } \\
\text { standards of behaviour or desirable actions shared by } \\
\text { members of a social entity; attach values to political action } \\
\text { that serve to legitimise the policies in a program through } \\
\text { arguments based on their appropriateness, often with regard } \\
\text { to underlying public philosophies and on the mechanisms by } \\
\text { which ideas take hold and are diffused, such as learning, } \\
\text { diffusion, transmission, and mimesis (Schmidt 2012). }\end{array}$ & $\begin{array}{l}\text { Moral } \\
\text { responsibilities, } \\
\text { climate change } \\
\text { responses as vital for } \\
\text { national } \\
\text { development, climate } \\
\text { change as a risk, 'no } \\
\text { blame' approach and } \\
\text { shared } \\
\text { responsibility. }\end{array}$ \\
\hline
\end{tabular}


Cognitive (cognitive frames of agencies)—connect the three levels by appealing to the prevailing logic and interests. Provide guidelines for political action and justify programs through arguments focused on their interest-based logics and necessity.

Rationalities of scientific arguments, economic, political.

\section{Discourses}

Manifesta Via multiple forms-narratives, myths, frames, collective tion memories, stories, scripts, scenarios, images etc.

Ways

representing, conceptualizing climate change in the national policy arenas of LCD, GG and SD.

Interactio Coordination among actors and actors coalitions to establish, n expand on and justify the discourse.

Facilitative actions, mediation and harmonisation of discourses within policy arenas.

Communication—deliberate, present and justify the discourse.

Media coverage, government communications in the national and international arenas.

Actors

Individua Organisations, governmental structures, agencies and etc. 1

\section{Discursiv}

e coalitions

Power Through

Over

In
Strategic coalitions formed through discourse coordination and communication.

shows through the ability of the most powerful actors to persuade others of the general validity of their arguments through persuasion with ideational elements

shows itself is in the ability of actors - normally powerful also in terms of institutional position and authority - not to listen, i.e., a capacity to resist alternative ideas, to exclude alternative ideas from the overall acceptable discourse; refers to agenda setting and protection, to the exclusion of alternative ideas from the table.

refers to the more subtle authority certain ideas enjoy over others by focusing on deeper discursive practices and institutional set-ups.
Sectoral ministries, academia, private sector, SOEs, IGOs, donor agencies, NGOs, knowledge brokers, policy entrepreneurs, grassroots organisations.

Cross-ministerial coalitions, bilateral cooperation in the framework of ODA projects.

Table 2. Concepts of discursive institutionalism with examples from the policy arena. Source: adapted from Schmidt 2008; 2010; Carstensen and Schmidt 2016 
In Article III, I rely on the concepts of discursive institutionalism outlined above to explore how different elements of meaning are presented, appropriated and deployed in policy discourses to deliver a particular political and institutional outcome, thus enabling certain forms of governance.

\subsection{Policy arrangement approach}

Article II uses the case of baseline setting in developing National Appropriate Mitigation Actions (NAMAs) to illustrate institutional dynamics, nationally and transnationally, as well as to ask whether demands for baseline setting express the ideal trade-off between actual GHG emissions reductions and the institutionalised requirements of accountability. In Article II I seek to understand why discourses acquire dominance while other understandings are discredited, what is the impact of scientific discourse and discourse around data management and what is the discursive role of actors. I also examine the impact of these discourses on institutional dynamics, identifying the policy arrangement approach (PAA) as an analytical framework with which to address the research problem. As developed by Arts, Leroy and Tatenhove (Arts et al. 2006; Arts and Leroy 2006), PAA is employed as an analytical tool for the purposes of this study, thus making it possible to describe the dynamics of changes in the policy process within a given policy domain, namely energy efficiency in the Vietnamese building sector. In Article II, elements of the overlapping policy arenas of climate change mitigation and low-carbon development in Vietnam are the objects of study.

PAA can be regarded as part of the network policy analysis family of theories, although insights from institutional theories have been added to the framework (de Jong et al. 2012). The proponents of PAA argue that while it was developed within the theoretical perspective of discursive

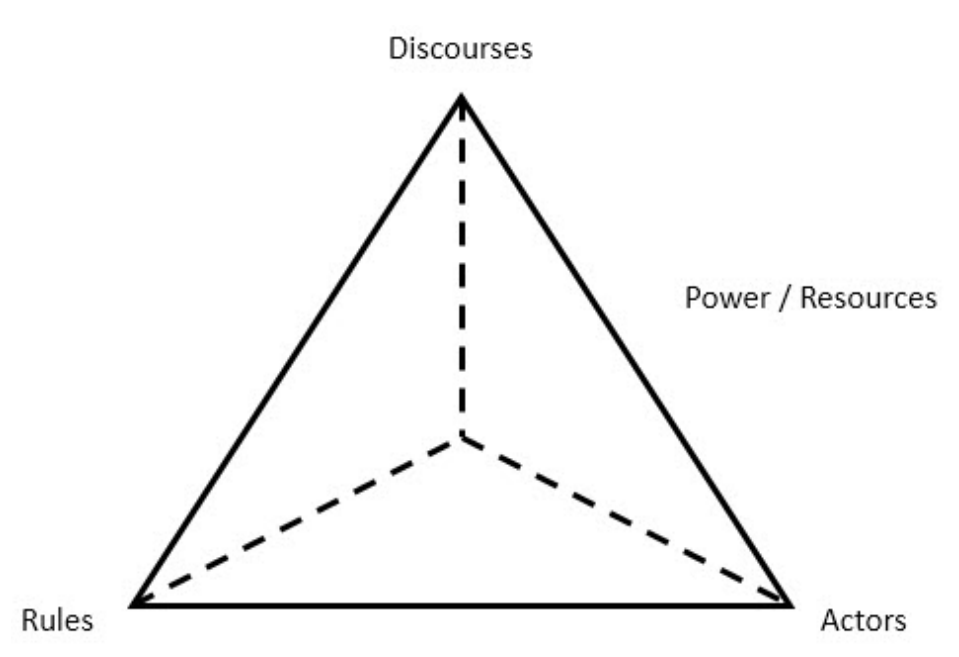
institutionalism, it provides researchers with more practical tools for analysis (Arts et al. 2010; Arts and van Tatenhove 2004). PAA considers both discursive and institutional processes by differentiating the four dimensions: discourse, rules of the game, actors and 
resources. The dimensions used to describe and analyse the policy process form a tetrahedron, each corner of which represents one dimension, as shown in Fig. 1. This serves as a framework for empirical and normative policy analysis and for recognising discourses and their effect on policy-making. A policy arrangement can be defined as 'the temporary stabilisation of the content and organisation of a particular policy domain' (van Tatenhove et al. 2000: 54), that is, the way in which a certain policy domain is (temporarily) shaped by discourses, actors, rules and resources. It incorporates structures resulting from processes, as well as from the interactions of policy actors and between the formal and informal rules (Arts and Leroy 2006). A policy arrangement is a concept used by the institutional approach to analyse processes of institutional change and stability.

\begin{tabular}{|c|c|}
\hline $\begin{array}{r}\text { Policy } \\
\text { arrangement } \\
\text { dimension }\end{array}$ & $\begin{array}{l}\text { Indicators of change } \\
\text { - In policy ideas: strategies for energy efficiency measures in } \\
\text { buildings } \\
\text { - In programmatic ideas: objectives and scope of energy } \\
\text { efficiency measures } \\
\text { - In background ideas: assumptions and values underlying } \\
\text { climate change mitigation actions }\end{array}$ \\
\hline Actors & $\begin{array}{l}\text { - Stakeholders, actors coalitions and their opponents } \\
\text { - Interactions (communication, cooperation, conflict) } \\
\text { - Legislation and regulation codifying energy efficiency, } \\
\text { baseline setting }\end{array}$ \\
\hline Rules & $\begin{array}{l}\text { - Procedures defining the roles and authority of actors (who } \\
\text { advises, who gathers the data, who interprets data, who } \\
\text { decides on energy efficiency measures?) }\end{array}$ \\
\hline Resources & $\begin{array}{l}\text { - Knowledge, skills, technology and finance } \\
\text { - } \\
\text { Resource distribution and access among actors }\end{array}$ \\
\hline
\end{tabular}

Table 3. Framework for assessing the institutional dynamics. Source: adapted from Wiering and Arts 2006; Arts and Leroy 2006

PAA was developed to analyse change and stability within policy arrangements empirically and to interpret changes in policy practices and structural changes in society (Liefferink 2006). The approach was developed as a critique of the 'rational' policy cycle and 'voluntarist' policy network models in the late 1990s (van Tatenhove et al. 2000; Arts et al. 2006; Arts and 
Leroy 2006). It builds on discursive approaches and discursive institutionalism (Schmidt 2005; Schmidt 2008; Arts and Buizer 2009). Since its origins, it has been used in case studies in the environmental policy domain (e.g. van der Zouwen 2006; Wiering and Arts 2006; Veenman et al. 2009; de Boer 2006; Phung 2014), exemplifying how suited the analytical PAA toolkit is to describing the dynamics of changes in policies by means of four interwoven dimensions.

The initial point of the approach is the interplay between mundane practices of policy-making and structural processes in society (Bogaert et al. 2009). As such, the research focus is on how actors and coalitions influence the discursive and more structural processes of policy-making and the way those processes have an impact on content and organisation, ultimately leading to a dynamic representation of the policy arena. This approach argues that neither actor nor structure should be studied in isolation, as they are intertwined and influence each other constantly. The same goes for the substance and organisation of a policy field. It is therefore the dynamics of the interaction of those aspects that should be analysed (Table 3).

Arts and Leroy (2006) suggest a certain sequence in the analysis of policy arrangements, also understood here as a policy arena. First, a discourse analysis of the policy arrangement should be undertaken with an emphasis on discursive change and continuity. Next, the relations between such discursive dynamics, the actors, coalition formation, the rules of the game and power relations should be assessed All four dimensions of the policy arrangement are indissolubly interrelated, such that a change in one dimension seldom stands alone but tends to have an impact on one or more of the other dimensions (Liefferink 2006). In order to understand the arena, the analysis needs to include all four forces, as they shape the policy arena. Policy areas consist of the processes, structures, and actors that are actively involved in the governing of a specific policy issue or problem (Sabatier and Weible 2007).

In PAA, policy discourses are interpretative schemes that range from policy concepts and texts to popular narratives and storylines, ascribing meaning to a policy problem and domain (Dryzek 1997; Fischer 2003). Several discourses are present in a policy arrangement (Fisher 2003). This difference and competition causes actors to group together in coalitions to enhance certain discourses and constrain others. The discursive dimensions of the PAA consist of the policy's substance (Liefferink 2006: 47) and the ideas that shape policy, 
while the other three dimensions refer to the organisational aspects of policy. The second dimension of the PAA, the actors, can therefore be labelled 'discourse coalitions' (Hajer 1995). The third dimension refers to the rules of the game that delineate a domain (van Tatenhove et al. 2000). Rules define the way the game should be played and within which boundaries. The final dimension, resources, is intrinsically linked to the exercise of power (Giddens 1984). In general, power must be regarded as the ability of actors and their coalitions to mobilise resources in order to achieve certain outcomes in the policy arena. It is assumed that discourse coalitions strive for hegemony in policy arrangements in order to realise their preferred policies.

In line with Phillips et al. (2004), in describing the case study in Article II, it was assumed that by identifying policy actors' appropriation and utilisation of ideas and discourses and their translation into policy, it is possible to identify discursive interactions with the potential for institutional change. 


\section{5}

\section{METHODOLOGICAL APPROACHES}

In this chapter, I first outline ontological, epistemological and methodological considerations. Secondly, I discuss the research design and data collection methods. After the principles of discourse analysis are introduced, I highlight its limitations.

The articles approach the governance challenges of low-carbon transformation from different direction and use distinct data collection and analysis techniques. In each article of this compilation dissertation I present the relevant background, methods and analytical strategies used in analysing the case studies. In this section I describe the overall analytical strategy and methodological approaches used. Whereas each individual article contains more detailed information on the methods used, the following section summarises the methods used and elaborates briefly on the research strategy. I also highlight the challenges of collecting data for policy analysis and elite interviewing in this specific political context, as well as the strategies used to address the methodological limitations and problems with data access.

The overarching aim of this dissertation is to explore how ideas influence the governance of transformations towards a low-carbon society. I regard the research design, the analytical approach used and the selected data collection methods as elements of the overall methodology of this dissertation. The research design adopted to address research objectives of this study is presented in section 1.4. Whereas my research ambition is explorative, my analytical strategy is multi-theoretical and draws on multiple methodologies. Therefore, my strategy for examining policy arenas with a significant degree of institutional and political ambiguity involves a mixture of qualitative and interpretive methods.

This dissertation employs a qualitative, interpretative methodology using a case study approach. Analysis is performed using the framework and terminology of governance theory and the theoretical perspective of discursive 
intuitionalism. In being exploratory, this qualitative research seeks to apply the concept of institutions and the theory of governance in an evaluative manner in order to develop a broad but preliminary understanding of the mechanisms and dynamics of decision-making and institutional change. The dissertation uses data and theory triangulation, as well as triangulation between data sets from respondents and document analysis, as a strategy whereby multiple perspectives on the same phenomena are considered by applying different theoretical lenses and analysing different data sources to validate the results through convergence (Mikkelsen 2005; Sarantakos 2005; Flick 2009).

\subsection{Ontological, epistemological and methodological considerations}

To study political phenomena, it is important to clarify one's commitments to a certain view of what one believes is possible and what is not possible in social reality. Therefore, it is necessary to clarify the ontological and epistemological premises of this work to assess the suitability of the chosen methodology and analytical strategy.

Ontology in political science concerns the implicit and simplifying assumptions about "political reality" that underpin explanations of political phenomena' (Stanley 2012). I share the conviction that ontology should not be defined as 'the world as it actually is' but instead as 'the world as political scientists assume it to be' (Stanley 2012). One's epistemological position reflects how we embark on learning about the world, constituting the 'view of what we can know about the world and how we can know it' (Marsh and Stoker 2002: 18-9). The research methodology is governed by the epistemological tradition, and ontology guides the methods used to collect and interpret information and data. Thus, 'to commit oneself to an epistemology is also to commit oneself to a position on a range of ontological issues' (Hay 2007: 117). Accepting that nature is partially based on the meaning we ascribe to it, it inspires a study of meaning making that reveals underlying political assumptions, values and, ideas. In the present case, the constructivist approach is necessitated by understanding and conceptualising sustainability and low-carbon development as ideational variables. The ontological assumptions are reflected in the choice of theoretical perspective in this dissertation outlined earlier. 
This dissertation is grounded in a post-positivist constructivist tradition that has distinctive implications for how the politics is studied. This means that the observer of political phenomena cannot be fully independent of the research topic being examined. Silverman emphasises that 'how we frame a research problem will inevitably reflect a commitment (explicit or implicit) to a particular model of how the world works' (Silverman 2013: 11). An interpretive approach to research is therefore specifically suited to answering the research questions outlined above. The methods employed in conducting this research, particularly the approach used to analyse and interpret the data, enables 'equivocal evidence' or 'biased views' on the part of the researcher, impacting on the direction of the study's findings and conclusions (Yin 2009: 14). With a constructivist epistemology, the researcher's values are recognised as an influence on the overall research process and can at best be managed and acknowledged by stating those values and applying research standards.

In broad terms, the methodology used in this dissertation is explorative and qualitative, the analytical strategy interpretative. The individual articles have different empirical and theoretical foci, though they are guided by the same analytical and methodological considerations.

\subsection{Case-study research design}

All four studies in this dissertation are designed as qualitative case studies. In a case study, a single person, program, event, process, institution, organisation, social group or phenomenon is investigated within a specified time frame, using a combination of data collection devices (Creswell 2012). Yin (1984: 23) defines the case-study research method 'as an empirical inquiry that investigates a contemporary phenomenon within its real-life context; when the boundaries between phenomenon and context are not clearly evident; and in which multiple sources of evidence are used.' In relation to the time scale limitations of the present analysis, I drawn on George and Bennett's (2005: 5) reference to the qualitative case-study approach as a 'detailed examination of an aspect of a historical episode to develop or test historical explanations that may be generalizable to other events'. As the case studies (particularly Articles II, III and IV) focus on a historical episode, such as reform of the electricity sector or low-carbon strategies and policy-making processes, thus aiming to test the explanatory potential of the discursive institutionalist framework, we identified the qualitative case study method as 
the best approach for this study. In that sense, the case studies in Articles II, III and IV were imagined as theory-evaluating exercises, as they were used to examine "whether existing theories account for the processes and outcomes of selected cases' (Venneson 2008: 228). The first case-study (Article I) was designed as a descriptive study to shed light on previously under researched phenomena (Vennesson 2008).

An overarching strategy in a case study in political science involves the employment of a mixture of methods for a qualitative inquiry, such as policy text analysis, elite interviewing and participant observation (Yin 2013). The case-study research method, designed as an in-depth examination of an underexplored research problem that asks why and how questions, is also useful for testing whether a specific theoretical framework applies to the explanation of a particular phenomenon in the real world (Bryman 2012). Lund (2014) refers to the approach as an 'edited chunk of empirical reality where certain features are marked out, emphasised, and privileged while others recede into the background.'

The nature of the research problem, like the aims and ambition of the dissertation, justifies the application of a case-study approach. According to Yin (2003: xi), the case-study approach is useful when the study aims to define research topics broadly and not narrowly, to cover contextual or complex multivariate conditions and not just isolated variables and to rely on multiple and not single sources of evidence. According to Thomas (2011), every case study must comprise two elements: 1) a practical historical unity that is the subject of the case study, and 2) an analytical or theoretical framework that is the object of the case study. I have aimed to draw up defined criteria to ensure that the cases examined provide sufficient insight into the phenomena of interest.

I used two criteria for selecting the cases studies (Articles II, III, IV): first, developing countries that have declared their adoption of a low-carbon development pathway 'early'; and secondly, a variety of political and economic circumstances and governance approaches to climate change mitigation. Developing countries that are embarking on pathways to low-carbon transformation and are at the early stages of rethinking governance approaches and decision-making regarding policy choices are potentially interesting empirical cases because the processes around decision-making can be observed within a limited timeframe and virtually 'in real time'. Data 
collection for Articles II, III and IV was conducted during fieldwork in Vietnam, allowing comprehension of the country-specific institutional setting to develop that facilitated interpreting the data in a wider context. The choice of data, i.e., VCM project documentation and interview data with project developers, guided the focus of the analysis in the case study presented in Article I. The VCM market was selected as a case study of the sustainability interpretation in the framework of market-based governance in order to contribute to the growing literature on the contribution of market-based mechanisms to sustainable development, largely focused on CDM, in underexplored geographical settings.

Even though this dissertation is based on multiple country case studies, it is not designed as a comparative study. The form of case study chosen in this dissertation is an exploratory case study, as it suits the research design of the dissertation, in which the research questions are constantly being revisited to accommodate new insights. The cases selected are treated as separate cases, that is, as single cases rather than replications of a single design (Yin 1994). In practice, this means that, although the research questions are similar, the studies' research designs are not identical but have been contextualised and adapted to the individual circumstances. In some regards, although all the cases in this dissertation have particular characteristics, they are impacted and influenced by the interplay between the global and national institutional contexts and ideas. Seeking out extreme or unique cases is one approach to ensuring the research provides evidence with which to observe and comment on conceptual propositions or validate proposed concerns (Yin 2009). A representative case is one that is meaningful because it builds in criteria that help the researcher to develop an explanation based on the conceptual propositions that underpin the study (Silverman 2005). I treated all four cases as examples of the interplay between global and national ideas and global and national institutions.

Exploring the selected phenomena through the lens of a common theoretical framework generates insights that are valuable in answering the research questions guiding this dissertation. The aim of the study suggests a historical perspective in studying the role of ideas behind political choices and institutional transformations in low-carbon development governance. One way of conducting case studies is the process-tracing approach, 'a procedure designed to identify processes linking a set of initial conditions to a particular outcome' (Venneson 2008: 224). The initial research design relied greatly on 
the process-tracing approach, aiming to establish the significant historical moments for institutional change and the role of ideas, based on participants' recollections and documented evidence. Process-tracing implies theoretically grounded and structured analyses of the prevailing discourses and discursive practices. Historical analysis where the researcher has no control over events requires a theoretical framework to guide data collection and analysis (George and Bennet 2005). I have drawn up units of analysis, analytical frameworks and set time periods for all four case studies.

Prior to data collection, I created a data-collection plan and mapped out potential data sources and groups of actors to establish an interview sample. However, while conducting fieldwork and during the initial data collection stage, I realised that my initial understanding that the empirical sources for the analysis would be 'easily' available and the time for data collection would be sufficient to ensure the diversity of the empirical sources required was false. In fact this is a well-recognised limitation of the case-study approach, which relies on process tracing to work (Venneson 2008). In order to compensate for the limited access I had to government databases and recordings of day-to-day policy discussions, I had to rely more on the grey literature provided by the donor agencies that work in Vietnam. As the intention was to establish the ideas not of individual policy actors, but of political coalitions, I had to assume that the analysis of limited empirical material and the reliance on documented policy outcomes, rather than processes of establishing discourses, would shed sufficient light on the ideas behind the political choices, how they are appropriated and utilised by the actors, and what are their implications for processes of institutional change. As the process-tracing was aimed at the establishment of ideas on the macrolevel (programmatic, background, policy), I have assumed that the approach allows me to establish what the ideas are, who are the actors and what are the implications of the ideational on modes of governance. The theoretical frameworks introduced above (PAA and DI) guided the data collection and the qualitative in-depth analysis.

\subsection{Data collection}

Case studies require multiple data collection methods, and each stage of the research process contributes to the overall explorations of the analytical framework. Yin (1984: 78) identifies these methods as including: 1) direct observation of activities and phenomena and their environment; 2) indirect 
observation or measurement of process-related phenomena; 3) unstructured interviews; 4) documentation, such as written, printed or electronic information about a company and its operations; and 5) a comparative analysis of bibliographical resources. Text was approached as data, assuming that 'a text corpus is the representation and expression of a community that writes' (Bauer 2000: 133).

Three broad sets of empirical material (texts) form the primary basis for this dissertation: (i) previous research, (ii) policy documentation and (iii) interviews. My principal means of data collection are described below and included textual analysis, interviews and participant observation. Data from interviews and participant observation were analysed in light of other empirical material.

The case study in Article I is based on project documents, a questionnaire and follow-up interviews. The initial data collection occurred in 2009. VCM projects in Sub-Saharan Africa were identified through the publicly available registries like the Gold Standard Registry, the CarbonNeutral Company Register, the VCS Registry System, the TÜV SÜD 'Blue Registry' certification database, the web directory of carbon offsets Carbon Catalogue and the project portfolios of major VER retailers. Questionnaires to obtain additional data were sent out to 23 organisations thus identified. The data were collected from February to April 2009 and identified a total of 78 relevant projects across the supply chain, including those in the pipeline and those that had been registered. These project data were updated in June 2011, when additional project documentation was collected. In order to identify key narratives and storylines, this was followed by semi-structured interviews with selected representatives of the organisations identified.

The data for the case studies in Articles II and III were collected during two field visits. The fieldwork was conducted in May 2013 and February-April 2014 in the cities of Hanoi and Da Nang, Vietnam. At this stage in the research process, the goal was to develop a contextual understanding of the institutional landscape, map out the policy arena and gain an overview of the context of the case study. Secondary data material had been collected previously, updated in the process of conducting fieldwork and afterwards to follow up on the themes that emerged. In the course of fieldwork, I made a decision to focus on the knowledge-management aspects of NAMA development in the energy sector to acquire a more detailed understanding of 
the policy-making specifics in a distinct segment of national policy arenas. This also allowed me to gain additional insights into the dynamics of the intersection between low-carbon development and climate change mitigation. The data consist of field notes: rich, detailed descriptions, including the context within which the observations were made; fieldwork descriptions of activities and interactions; interview transcripts; memos of meetings; and organisational descriptions of functions and activities. Secondary data included relevant policy and project documents, peer-reviewed literature and grey literature (reports and assessments by international organisations working in the region). The case studies used mostly 'hard' primary sources, including official governmental documents (formal and informal policy documents of various governmental agencies) (Articles III, IV). The interviews were treated as less important sources in the case study for the Article III, while in the case study for Article II the interviews and participant observation were important sources of information not available elsewhere.

The following procedures were adopted for onsite data collection. After the first field visit and initial examination of the national policy arena for climate change mitigation, I focused on the example of energy efficiency policy-making in buildings, while also investigating the national context. Therefore, I prepared four different interview guides based on their relevance to each interview situation, as well as on the informants' involvement in policy practice. Interview questionnaires were designed with key open-ended questions, which I grouped thematically to be used for reference and as prompts if necessary, as they could be used more spontaneously in the interview without the need to refer to the schedule explicitly.

In order to 'construct validity' (Sarantakos 2005), I have shared my fieldwork guide, interview protocols and data collection strategy with colleagues. I developed an on-site interview protocol prior to fieldwork and adjusted it during the field visit. I kept a research diary and updated the research log accordingly. I took field jottings and descriptive notes during the interviews when audio recording was not an option. Notes from direct and indirect participant observation were compiled during and right after the event. When I could not take field notes, I tried to make field jottings directly after the encounter with the informant. The approach of gisted transcription was used in transcribing the interviews. Gisted transcription is a term for a way of transcribing coined by Dempster and Woods (Dempster et al. 2013) that denotes a form of summarising that a researcher can use whenever it is felt 
appropriate for the research. It is 'to create a summary transcript that captures the essence', while not necessarily transcribing the parts that appear to be irrelevant for the purpose of the interview (ibid.).

\subsubsection{Policy analysis}

I performed a textual analysis at all stages of the research and to a certain degree for each case study. Textual analysis of the policy documents was undertaken particularly in the context of the example described in Article III on climate change mitigation and low-carbon development policy in Vietnam. In addition to the interview notes and transcripts, I mainly examined three types of text: national and sector-specific legislation and regulation, NAMA proposals, and presentations by policy actors reflecting the policy development process.

Textual content was analysed qualitatively for programmatic ideas and policy assumptions, as well as for background ideas to identify discursive elements using the discourse analysis method. Key identified narratives and storylines were analysed using pre-coding and open coding methods (Saldana 2015) in order to establish meanings and narratives in the discourses described. Transcripts and documents were examined for evidence of discursive agency, key narratives and storylines, the discursive power of actors, policy practices, assumptions regarding the institutional context of policy-making, types of ideas and records of stakeholders' interactions. Throughout the analysis it was important to contextualise the ideas and discourses that were prominent in institutionalising climate change mitigation policy.

\subsubsection{Interviews}

In political science and studies of policy, interviewing is used for various purposes depending on the objectives and the stage of the research project (Mosley 2013). The interview is commonly considered an exploratory conversation (Ritchie et al. 2013). In this dissertation, interviews are both a primary source of data (Articles I, II and III) and of preliminary data used to identify key informants, gather textual material, acquire insights into policy practice and gain exposure to the use of language in order to explore the interpretation of background, programmatic and policy ideas by the political actors (Article III). Based on the methodological literature, I opted for semi- 
structured interviewing as an effective approach when seeking meaning (Morris 2009).

For Article I, interviews were conducted by telephone after the questionnaires had been sent out to potential respondents. Interviewees had a choice of response formats. The decision to conduct interviews by telephone, regardless of its various disadvantages, was made since the telephone interviews could prove a 'versatile' data collection tool (Carr and Worth 2001: 521) supplementing the initial survey data.

For the case studies in Articles II and III, interviews were conducted during two field visits. Out of a potential 79 respondents identified, 58 were interviewed for both case studies. As some respondents were not sufficiently involved in the policy-making processes that were relevant to the study, only 39 in Article II and 27 in Article III were considered relevant for the purposes of analysis. A principle objective of the field visits to collect data was to examine the frameworks that guide stakeholders' definitions of low-carbon development and thus the policy solutions and responses for bringing about low-carbon development (case studies described in Articles II and III). The purpose of the semi-structured interviews was to gain insights into a range of views and perspectives that are representative of the discourses identified in the policy arena through textual analysis and to gather additional material and identify other relevant stakeholders (Gaskell 2000). Interviewing provides the tools for a researcher to gain access to political constructions of meaning that may otherwise be difficult to examine (Beamer 2002). Interview-setting provides an opportunity to approach the individuals who are participating in political and policy-making processes at first hand. This served as a rationale for supplementing the document analysis with the interview data to allow for triangulation through the analysis of different data sources (Denzin 2012). Another rationale for the decision to use the interviews in the two case studies of Vietnam's national policy arena (Articles II and III) derived from the literature on elite interviewing.

Elite interviewing is regularly used to: i) corroborate what has been established from other sources; ii) establish what a set of people think; iii) make inferences about a larger population's characteristics and decisions; and iv) reconstruct an event or set of events (Tansey 2007). The technique is used to obtain information that is otherwise unavailable (Manheim et al. 2005), such as reflections on meanings or historical accounts of mundane policy- 
making practices. There is no agreement among those who use the elite interviewing approach regarding who are the 'elite' in the political and policymaking setting (Harvey 2010). For the purposes of my research, I limited my sample to those who participate in climate change mitigation, low-carbon development and green-growth policy-making. Therefore, since qualitative research and interview methods are often criticised for not being transparent and the results difficult to replicate, it is particularly important to be transparent about the sampling strategy. The sample included members of the bureaucratic administrative elite (public service officials), the staff of international organisations and the representatives of donor agencies. The interview requests were sent out to ensure a wide spectrum of policy actors representative of national policy arena stakeholders. Following the literature on interviewing elites in political science (Spector 1980; Aberbach and Rockman 2002; Hochschild 2005; Harvey 2010; Mikecz 2012), I recruited and interviewed people for their positions in government agencies, international organisations and academia. In relation to the example of baseline setting in the building sector (Article III), I also approached stakeholders from the private and civil-society sectors to gain further insights into policy-making practices. The sampling was based on recommendations by representatives of the Ministry of Natural Resources and Environment in Vietnam and further snowballing techniques.

The literature on elite interviewing emphasises two principal difficulties in using the approach, gaining access and dealing with elites' power (Harvey 2010). While the issue of access can be confronted by employing a variety of strategies, the issue of power asymmetries is more difficult to address. The literature on elite interviews tends to be sceptical of the reliability of the data obtained from such interviews due the asymmetrical power relationship between the respondent and the researcher (Lilleker 2003; K. E. Smith 2006; Bygnes 2008). Reflecting upon the issue of power and the potential of the interviewers to control the interview by questioning methods and research credentials (Delaney 2007) or to largely direct the conversation towards the activities of the UDP and not the goals of the research project, I repeatedly emphasised the academic nature of the interviews and my role as a researcher. A number of other factors might have influenced the direction of conversations due to my positioning as a researcher. At the time of the fieldwork that was carried out to obtain data for the case studies described in Article II and III, my access and introduction to the policy arena being researched was secured through my affiliation with the UDP's and UNEP's 
project activities in Vietnam. Therefore, informants, government officials and key policy experts were initially identified through the national Climate Change focal points and respective ministries, as well as through their association with the UDP's project activities in Vietnam. Furthermore, I used a snowballing sampling technique to identify potential informants and supplement the initial sample (Tansey 2007), asking interviewees to provide other interview opportunities by nominating other individuals they felt could be relevant to the research project.

The effectiveness of this approach depends on the communication skills of the interviewer (Bryman 2012) and the understanding of the context of the interview. I defined the themes and questions based on the document analysis and stakeholder mapping performed beforehand. The interview scripts were prepared in advance (Annex A) to guide the conversations. Nonetheless the respondents were encouraged to elaborate on the questions during the interview setting. Since the purpose of the interviews was to 'to get at the contextual nuance of response and to probe beneath the surface of a response to the reasoning and premises that underlie it' (Aberbach and Rockman 2002: 674), interviewees could expand on their responses as they considered necessary. The nature of the interviews was flexible, therefore the wording of the questions, and sometimes the subjects, was not always the same. The interview protocol and the script were adapted for different types of interviews and respondents to improve data quality by focusing on their unique knowledge and experience, while primarily aiming to uncover issued related to the institutional contexts and practices of decision-making, and their views on low-carbon development and practices of knowledge and data-management (Article II). I designed the protocol to include a set of standard questions to be asked in every interview setting. The follow-up and respondent's specific questions were useful in encouraging wide-ranging discussions and in-depth responses about developments within the policy arena of low-carbon development and how climate change mitigation, low-carbon development and green growth are interpreted and institutionalised. I relied on open-ended questions and probes for additional responses (Willis 2006).

I considered several factors while evaluating the data obtained from the elite interviews, including the style, manner, experience and position of the interviewee and the comprehensibility, plausibility and consistency of their testimonies (Aberbach and Rockman 2002; Lilleker 2003; Tansey 2007; Mikecz 2012). The data consisted of verbatim quotations and contextual 
descriptions. Verbal accounts were used to identify actors and interactions between them in producing and legitimizing ideas about climate change mitigation and development as manifested in policy. Analysis and interpretation were based on a general analytic framework (Yin 2009) which defined priorities for what to analyse and why. This comprised three stages: 1) analysis of individual interviews and transcripts (within-case analysis, initial coding and categorisation); 2) identification of shared themes (categorical aggregation and a search for patterns); and 3) analysis of shared themes. Data analysis followed an iterative process, from data organisation to establishing patterns, sharing preliminary observations with stakeholders, gathering complementary data material and refining the analysis (Mikkelsen 2005). Each transcript was analysed separately as a unit of analysis both to understand the experience of those individuals and to identify emerging themes (within-case analysis). Storylines, policy problem solutions and key concepts that emerged from the textual analysis were interpreted in accordance with the discursive institutionalism framework discussed in section 3 to identify the main components of discourses (as described in the literature). Themes (codes) were consistently classified as characteristic of discourses.

Most of the interviews were recorded digitally or written up in the form of 'field jottings' (Emerson et al. 2001). Some interviewees declined to be recorded, so the data are only available in the form of interview notes. Some comments during the interviews were provided 'off the record' or were not to be used explicitly. Several respondents preferred not to be quoted, which is why I have not included direct quotations in Articles II and III. I only provide a list of respondents, and not the actual transcripts of the interviews. I also acknowledge that the choice of an elite interviewing technique poses particular ethical challenges because of the professional roles of potential participants (Aberbach and Rockman 2002; Lilleker 2003; Tansey 2007; Mikecz 2012). The officials representing government agencies rarely departed from the official line of their agency, and conversations largely focused around administrative roles in policy-making and cooperation with international agencies. I have aimed to address this issue by stressing the confidentiality of the interview data. Confidentiality and anonymity can sometimes be limited by the very nature of participants' professional roles, and so the confidentiality agreement in professional and elite interviews is absolutely central (Dexter 2006). To address these concerns, I asked for consent prior to each interview to include the option of anonymity. A significant number of 
informants requested not to be quoted or identified, especially those in middlelevel positions in government agencies or acting as the voice of their organisation. Therefore, all participants remain anonymous in this dissertation and other publications. I have replaced the organisations and agencies with generic terms without identifying departments and individuals, while trying to preserve the meaning of the verbal accounts.

\subsubsection{Participant observation}

In addition to the elite interviews, I had the opportunity to engage in a more interactive process of data collection by communicating with actors in the policy arena in different settings as an active participant. I participated in three workshops addressing sectoral NAMA development and one high-level meeting discussing implementation of Vietnam's Green Growth Strategy. Interacting with various stakeholders during workshops and meetings allowed me to develop a better comprehension of the field of policy study, gather empirical material, map out relevant stakeholders, outline institutional arrangements, identify key institutions and policy portfolios, engage informally with policy actors and development practitioners and gain insights into policy discussions. The participant observation allowed additional perspectives to emerge on inconsistencies between the rhetoric of declared policy principles and policy practices, including as emphasised by individual policy actors.

\subsection{Discourse analysis as a method}

Approaches to discourse analysis differ in their ontological and epistemological positions, as well as their methodological premises. Individual traditions of discourse analysis originate with diverging interpretations of the meaning of discourse (Torfing 2005). Discourse analysis has been used to describe a wide range of research practices, with varying epistemological underpinnings and analytical practices (Fairclough 2001; Wetherell et al. 2001). Thus, 'discourse analysis' is a flexible term (Graham 2005), and there is no 'cookbook style recipe' for how to it (Gill 2000: 177). As such, the discourse analysis method is applicable if it is defined by the ontology and epistemology of the study. Yet a starting conviction shared by all discourse analysis approaches is that how one knows and understands social phenomena shapes our worlds. Therefore our knowledge and understanding of the world is neither neutral nor complete, thus bringing claims regarding objective truth 
and the existence of a single rationality into question (Gill 2000; Graham 2005; Hook 2007). Given its interpretivist lens, discourse analysis appeals to me as a researcher. Due to the emphasis in this dissertation on the ways in which political phenomena are spoken of, conceptualised and defined by actors, it resonates with my understanding of the role of ideas and discourses in shaping institutions, thereby crediting ideas and discourses with a crucial role in constructing political arenas and transforming the politics of climate change mitigation. While carrying out discourse analysis (Articles I, II and III), I focused on the representation of what is being governed, or in other words, how the policy problem is defined and depicted, what type of a solution to policy problem is advocated and by whom, and what are the particular features of policy instruments (Verloo and Lombardo 2007). In Article IV we focused on uncovering what types of arguments are present in constructing the meaning of the policy problem (contextual, technical, or appealing to values, ideational).

The common theme linking different analytical practices of discourse analysis is the rejection of language as reflective of a concrete 'reality' (Jørgensen and Phillips 2002). Instead, language is seen as the maker of events and constructs, and as enabling different subject positions and practices undertakings. Nonetheless all discourse analyses are aware of the 'role of language in constitution policies, polities and politics' (Feindt and Oels 2005). In the study of politics, it is acknowledged that discourses are manifested not only in political rhetoric, but also in institutional structures, practices and events' (Sharp and Richardson 2001: 199). The analysis of policy discourse must accept the importance of discursive and social practices beyond their linguistic representation and recognise that the text is not an isolated object to be studied as if it is a closed system. Discourse analysis is not just a matter of examining language and what is being said, it also includes the institutional context in which this is done and which co-determines what can be said meaningfully' (Hajer 1995: 2). According to Fischer (2003: 191), the aim of discourse analysis lies in:

[...] establishing interconnections among the empirical data, normative assumptions that structure our understanding of the social world, the interpretative judgments involved in the data collection process, the particular circumstances of a situational context (in which the findings are generated or the prescriptions applied), and the specific conclusions'. 
This resonates with the suggestion that we follow four stages in the process of discourse analysis, which I adhere to a certain degree in each of the articles in this dissertation. These include (Yanow 1999):

i. Determination of the 'artefacts' (language, objects, acts, texts) that are the carriers of meaning in a specific policy arena.

ii. Identification of the 'communities of meaning' that are relevant to the policy issue that produces the texts and defines who is involved in policy construction.

iii. Establishment of the relevant discourses and storylines (Hajer 1995).

iv. Identification of potential conflicts, discursive struggles (ibid.) and discursive contestations and conflict and how they reflect different interpretations by different communities.

The Article I case study of the conceptualisation of sustainability in voluntary carbon markets applies the discourse analysis approach along the lines of Hajer's approach (Hajer 1993; 1995) to frame the discourses and structure the discourse activity. However, this approach does not provide sufficient tools to explain the institutional role and dynamics of the policy arena that the dissertation aims to examine following the first case study, which emphasises the role of discourses in mitigation practice. Since patterns of governance are fundamentally institutional matters, a framework of analysis enhancing understandings of the politics that underlie institutional formation and practices will contribute to an understanding of those phenomena as well. The value of this case study for this dissertation is mainly that it provides an analytical starting point suggesting other areas of ideational research with an impact on the choice of analytical and theoretical strategies in subsequent studies. For instance, the argument that transnational actors dominate the definition of 'policy problem solutions' and select the governance approach suggests that actor-centre analysis could provide additional insights into policy analysis. Recognition of the discursive role prompts theoretical investigation of alternative explanations for the manifestation of power in governance. Finally, the analysis suggested that grasping the institutional context of climate-change mitigation is the key to understanding the transformation of governance.

Similarly, to understand how the notions of low-carbon development and climate change mitigation are manifested in the climate change policy arena in Vietnam, the roles of particular discourses and actors and issues of power 
in climate change politics, I have applied a discursive approach in Articles II and III. I analysed policy texts for accounts of discourses, discursive manifestations and interactions, i.e. for content (key narratives and storylines) and background meaning, as well as changes in the ideas that define climate change mitigation policy. I focused on detection of the critical arguments, including ideological ones, used by various actors to construct meaning and use their coercive power to advocate governance and policy solutions. Although the theoretical approach combines a focus on both institutions and discourse, the main emphasis of the research is ideational. Hence, the scope of the analysis of distinct discourses is not as wide and comprehensive as it could be.

\subsection{Limitations and challenges}

Any exploration of the political role of ideas faces several analytical and methodological challenges. This work is a compilation of separate case studies of processes within the boundaries of defined policy arenas over a defined period of time.

One of the major challenges for this dissertation is the very choice of the particular concepts that orient the inquiry, emphasising particular dynamics, processes and relations while disregarding others (Lund 2014). This study does not attempt to provide a detailed map of institutional arrangements and actors or comprehensive accounts of political processes. In practice, this has meant prioritising a contextual focus on the discursive manifestations of ideas and meaning construction by actors within the boundaries of national level policy-making (Articles I, II and III). I do not argue that examples of discursive practices in the institutional settings observed here are complete or representative of all actors. However, the analysis allows discursive influences on institutional practices to be identified and also provides insights into the underlying rationale of policy choices.

Conducting an analysis that can account for both agency and structure requires time and scope, and in the case of this project both are limited. To respond to the methodological limitations of the study, the analytical approach had to be revisited continuously. If applied in ideal setting, the research design based on the analytical framework implied observations of the same processes performed over time. However, from the data that was obtained, it was unlikely that national discussions over time could be traced or a clear 
timeline of discursive changes established (Article III). To address this, I broadened the scope to include discourses from the overlapping policy arenas. To gain deeper insights into the conditions for discourse formation, I narrowed the scope to the buildings (Article II) and electricity (Articles II and III) subsectors. Nevertheless, limited data access and transparency, a low level of interest in participation and restricted access to relevant actors imposed critical constraints. However, while these could be ascribed to the particularities of the political regime in Vietnam, the issue of access is an accepted difficulty in elite interviewing. Moreover, data collection in developing countries has additional challenges. Consequently, I have revisited the feasibility of elite interviewing in the case studies described the Article IV.

It is a demanding task to search not only for explicit language and expressions, but also for underlying assertions in in searching for the philosophical ideas of the political actors. The subjectivity of the interpretations of the uncovered meanings is inevitable. This has proved particularly true in the context of studying Vietnamese politics, as it is often just as important to understand what is not being said as what is being said. Therefore comprehension of the cultural context, including how language is used in the construction of meaning, is key in conducting discourse analysis. I have acknowledged the need to advance the comprehension of the cultural context and have consulted practitioners with previous experience of working in the context of policy development in Vietnam to gain further insights, and also encouraged input from my interpreter. However, I believe that, while there were limitations imposed by the inescapable cultural incompetence of an outsider to Vietnamese politics, this should not be a reason for not attempting to investigate discursive politics. While a common language might be spoken in a policy arena, where not only national actors but also transactional actors are extensively involved, the meanings assigned to the institutions vary, and the implications of both backgrounds and programmatic ideas are worth examining through the lens of discourse analysis.

To meet these analytical and methodological concerns, I have followed the principle of explicit reflexivity, since setting limits, choosing the units of analysis, identifying the relevant actors and establishing a relationship with them is inevitably open to bias. I have acknowledged and reflected on my positioning as a researcher within a particular discipline, as a representative of an international organisation and a foreign university, and as a nonresident young woman to take account possible bias into account. 


\section{6}

\section{SUMMARY OF ARTICLES}

In this section the individual essays are placed in the overall context of the dissertation and their individual empirical and analytical contributions highlighted.

\section{ARTICLE I. Conceptualisations of sustainability in carbon markets}

Focus

Analytical framework

Method

Theoretical and empirical contribution

Guiding questions

\section{Extended abstract}

This article explores how values and ideas shape the existing market space and contribute to constructing the meaning of sustainability, as well as their
Presents the theoretical concepts of sustainability as exercised by actors in a particular arena in the context of market-driven governance

Discourse analysis (Hajer and Dryzek)

Case study

Argues that the governance of sustainability takes place according to a series of horizontally linked practices that are central to their exercise; provides a brief analysis of actors; demonstrates how power is exercised through discourse and ideational interpretations

What are the discursive framings that impact the prevalent approach to sustainability adopted by market participants?

How do discursive framings impact project development? 
implications for climate change mitigation actions and approaches to sustainable development. By investigating the role of actors in defining the institutions of a market-based form of climate change governance, we identify the dominant narratives and underlying ideational commitments by studying how the various actors involved in the voluntary carbon market interpret, adopt and utilise discourses to promote their interests. The objectives of the article are to outline the roles of the actors who are participating in the market mechanism and to evaluate the dominant approaches to sustainability.

Empirically this article focuses on market responses to climate change, specifically a particular example of voluntary carbon market development in sub-Saharan Africa, and it also seeks to identify the principles of sustainability that carbon markets draw upon. The analysis is based on an evaluation of 78 projects in the voluntary market across supply chains in 23 countries, including those in the pipeline and those that have been registered under the voluntary standards. Voluntary carbon market projects represent a valid share of the market and are often perceived as aiming to contribute to the wider goals of sustainable development by focusing on low-income communities and small-scale projects in underrepresented regions that might be excluded from the CDM. Moreover, the regulated and voluntary markets, while complementary in some areas, overlap in others.

The article argues that evolving institutions and expanding market spaces are defined using the terms of the northern 'experts', private-sector and nongovernmental entities, which design the offsetting projects and decide whether to emphasise the GHG emission reduction aspects or include wider aspects of sustainability. The local communities are mostly regarded as project implementers and as potentially gaining from the co-benefits delivered by the offsetting projects. We argue that the prevalence of neoliberal and technocratic ideas and values that prefer weak ecological modernisation and are translated by the dominant northern market actors, coupled with the contemporary climate regime, marginalise alternative perspectives on climateconstrained development, thus weakening the prospects of averting the dangerous impacts of a changing climate. As already noted, market governance in the forms it takes in the contexts of the study is non-inclusive, and the power of dominating discursive dimensions that shape development opportunities in the region has to be recognised. This has an impact on the types of project that are to be developed in the region and the actors to be 
involved in the future market development. Current responses linked to the weak ecological modernisation discourse limit the ability to change the traditional technocratic, expert-driven approach to governing climate change mitigation. Informed by the empirical evidence generated by this study, one can look ahead to how carbon markets may be shaped in the region, what development outcomes they may promote and how the actors are shaping the future of a new carbon-restricted economy.

As a first case study, this article has inspired the further development of a theoretical framework and directed the analysis of this dissertation towards the focus on power in, over and through ideas in studying institutions of governance. The article contributes to an understanding of how actors may impact on governance and its institutions and how specific interactions between governance and practice may change approaches to climate change mitigation. 


\section{ARTICLE II. Could baseline establishment be counterproductive for emissions reductions? Insights from Vietnam's building sector}

Focus

Analytical framework

Method

Theoretical and contribution

Guiding questions
Building sector, national local institutions, actors in the national policy arena, discourses

Discursive institutionalism

Document analysis, concept-centred analysis, participant observation, elite interviews

empirical Application of the PAA analytical framework and concepts in discursive institutionalism to the study of policy development and implementation in the context of a developing country. Empirical material representing the logic behind the establishment of baselines in the buildings sector in Vietnam, collected and systematised.

What are the ideas and discourses about what constitutes data in designing and implementing climate change mitigation policy?

How are ideas behind political choices appropriated, utilised and translated by actors into policy-making practises of climate change mitigation and lowcarbon development?

How are current knowledge management practice affecting the feasibility of baseline settings in the buildings sector in Vietnam?

\section{Extended abstract}

Baseline establishment is commonly questioned as an initial step in developing NAMAs in order to facilitate the demonstration of a deviation from such baselines. Baseline requirements are traditionally not questioned by policy practitioners. Thus, significant development resources are allocated to the establishment of baselines and the bridging of data gaps, often without consideration as to whether this is a necessary instrument for NAMA implementation. We suggest omitting the lengthy and resource-consuming practice of establishing baselines and recommend proceeding forthwith to the 
planning and implementation of mitigation and energy efficiency policies. Instead, as conditions vary significantly in different contexts, it would be more appropriate to measure the initial situation, establish the 'base point' and monitor progress from that point. The present article can serve to motivate policy-makers to question their approaches to policy development and consider alternatives in order to maximise the cost efficacy of NAMA programmes and facilitate their implementation.

This research is concerned with the governance of climate change mitigation and the development of a policy to regulate energy efficiency in buildings. The article contributes to understanding the fragmented governance of energy efficiency by identifying key institutions related to the underlying discourses, power relations, resource distribution and coalitions in building-sector policy in Vietnam. Insights are provided into the contribution of Vietnam's horizontal and vertical institutions of climate governance in relation to a future low-carbon society during a period of relative uncertainty in the global climate governance architecture. The work is related to the theme of institutional change in national and international climate change governance. We use the example of the baseline requirement in developing NAMA proposals. We question the requirements for establishing baselines for GHG emissions, as well as the reasoning behind rationalising the baseline necessity for NAMAs. In doing so, we also highlight the role of scientific knowledge and technical expertise in national policy-making and analyse how different actors employ prominent manifestations of international discourse on climate change, together with scientific and development arguments, to promote their positions.

This analysis reveals that, in addition to domestic efforts and challenges, the international agenda greatly influences the energy efficiency policy arena. After analysing knowledge management practices, we conclude that limited national institutional capacity, policy solution framings within the dominant international discourse and a neglect of the wider political economy context are creating a path-dependent lock-in that is impeding the delivery of necessary and timely policy responses. The article demonstrates how the principles of ecological modernisation, a discourse originating in northern Europe, are applied in the policy context of a developing country. It shows the impact of the ideational background and interplay of the domestic developmental discourse and the dominant discourses in the global climate regime on national sectoral policy-making. The case study outlines how ideas 
about policy measures and their feasibility are powered through technical expertise. We emphasise that access to hard data is a powerful aspect of policy problems and consequently of the definition of policy solutions. This research responds to the wider research agenda in the ideational scholarship to approach quantitative data and indicators as powerful ideational constructions that shape public policy and political debates (Béland 2016). It contributes to the growing scholarship concerned with the translation of the ideational and discursive frameworks of global climate change regimes into local institutional, socio-economic and political contexts in developing countries.

Finally, the article presents lessons to be learned from this particular case study of policy processes, reflecting the role of international actors and discourses in this. As a policy recommendation for practitioners and decisionmakers, we suggest abolishing the baseline in favour of adequate monitoring and evaluation. We believe that this is an appropriate alternative approach to policy development stemming from our analysis, one that can facilitate the development and implementation of mitigation measures in the buildings sector in Vietnam. 


\section{ARTICLE III. Claiming, fixing and imitating transformation: the case of the low-carbon development policy arena in Vietnam}

Focus

Theory

Method

Theoretical and contribution

Guiding questions
National climate change mitigation and greengrowth policy arenas.

Discursive institutionalism.

Document analysis, concept-centred analysis, participatory observation and elite interviews.

empirical The article analyses the approach to low-carbon development in the context of the national policy arena in Vietnam. It discusses the performance and appropriateness of global climate change mitigation narratives, the impact of identified discourses and the roles of discursive coalitions in the establishment, institutionalisation and advancement of approaches to low-carbon development in the context of Vietnam's climate change politics. It applies the concepts of the discursive institutionalism framework in the context of a complex policy arena in a developing country. It includes empirical discourse analysis, stakeholder mapping and policy analysis.

How are ideas underlying political choices appropriated and utilised by actors and translated into institutions and policy-making practices related to climate change mitigation and low-carbon development?

What is the role of actor groups such as the state and non-state actors in defining the institutions and governance of climate change mitigation?

How are processes of institutional change defined by the political and institutional contexts and ideational changes? 


\section{Extended abstract}

Despite the increase in the literature on mainstreaming the climate change agenda into development priorities, limited consideration has been given to the politics of institutional change. This work adds to the existing constructivist perspective on climate change governance by paying explicit attention to the role of ideas and institutions. Vietnam is the sixth most vulnerable country to climate change, yet the government has announced a voluntary commitment to include climate change mitigation measures in its climate change response strategy, thus shifting the previous focus away from adaptation actions as a priority. Population growth, the rate of urbanisation, ambitions of industrialisation and the government's determination to maintain high rates of economic growth over the next decades make achieving declared mitigation targets and diverting the economy towards a low-carbon model a challenging task. Vietnam, with its top-down, centrally planned, target-orientated and state-led climate change governance and commitment to maintain its rate of development, is an interesting case for investigation of how ideas about development impact on climate change governance. It provides an example of how the new political agenda is institutionalised on the level of national policy and outlines how existing institutional innovations relate to the background to and programmatic ideas about how to achieve long-term transformations.

In this article, I investigate the case of the institutional development of climate change mitigation in Vietnam. I examine institutional arrangements and national policies for their relevance in governing the transition to lowcarbon development in Vietnam and identify the roles of key actors in obstructing or promoting institutional change. The analysis is based on data obtained through 27 elite interviews and supplemented by a survey of policy documents and participant observation. I describe the approach to designing transitional pathways and discuss the potential of existing policy measures, institutional arrangements and frameworks at the national level within the existing policy arena of climate change mitigation. By applying the theory of discursive institutionalism, this article reveals that in practice the national institutions and initiatives examined tend to favour technological transitions over institutional change and to be reliant on hierarchical authority and traditional patterns of steering to a greater extent than intended. I also show 
that the example I present of a low-carbon development strategy currently only complements other existing policy initiatives and follows an established route of linear policy-making and apolitical, techno-managerial solutions to the climate change challenge. The 'technocratic neoliberalism' of global processes within the UNFCCC is reflected in the policy preferences that have been announced, thus marginalising alternative debates on the feasibility of alternative solutions. However, in the present institutional and political context, the control-and-command approach built in to the policy-making and the all-pervasive presence of the state that sets the agenda outweighs promarket arguments and calls for liberalisation.

The article concludes that climate governance needs to be strengthened by institutionalizing a focus on the long-term goals of transformational change and by improving reflexivity among the actors in the policy arena regarding the particulars of the institutional context and present political agendas. Greater awareness of the underlying values and norms of climate politics is necessary to identify the institutional and political challenges and thus understand change. If ideas and discourses of transformational change are to change modes of governance, the institutional context needs to be confronted by their advocates, thus improving reflexivity regarding the particulars of the institutional context. Policy actors' improved reflexivity regarding the institutional context and a critical evaluation of the political choices built into the policy discourses they co-construct and within which they operate is crucial if they are to change the mode of climate change governance in Vietnam. 


\section{ARTICLE IV. The politics of ideas in low-carbon infrastructure development: transformational change and the governance of energy systems.}

Focus

Theoretical perspective

Method

Theoretical and contribution
National energy infrastructural development in two different political economic contexts of electricity reforms in Mexico and Vietnam

Constructivist institutionalism

Text analysis, concept-centred analysis

empirical This article (i) makes the case for the applicability of constructivist institutionalism approaches in a study of the multi-level governance of electricity sector reform; (ii) identifies the key rationalities for energy reform and the pursuit of climate change strategies; and (iii) describes the ideational and institutional configuration of powerful actors, with a focus on the diversity of claims.

\section{Extended abstract}

The transformation of energy systems is increasingly recognised as a necessary social response to mitigating climate change, with the potential to catalyse a paradigmatic shift towards decarbonisation. Investments in energy infrastructure are seen as part of a wide number of changes required in the long-term visions of national governments, civil society and economic institutions. Endeavours of such magnitude represent a unique challenge to climate governance, creating implications for multiple levels of decisionmaking: the challenge is in coordinating these various levels. While nation states have traditionally been recognised as key actors that are expected to design, steer and coordinate policy, sub-state, non-state and public-private actors in climate governance are gaining political power over decentralised, contentious, large-scale infrastructure, challenging such state-led models of energy transitions.

Policy choices result not only from the power interplay of various actors' interests, "but also from the battle of ideas through discourses and deliberation' (Schmidt 2009: 541), re-focusing governance through the capacity of actors 'to influence normative and cognitive beliefs' (Carstensen and 
Schmidt 2016:4), across various levels of governance. The role of ideas is pivotal to governing the highly political response strategies to climate change mitigation, refocusing governance and redefining the role of institutions by shaping the vision of low-carbon transformations. The 'transformative power of ideas' (Schmidt 2008) denotes the political power defining the political reality. Actors exercise their ideational power by being persuaded to adopt particular views (power through ideas), the imposition of ideas, the elimination of alternatives (power over ideas) and the production of subject positions, as well as constraining what can be legitimately considered (power in ideas) policy options (Carstensen and Schmidt 2016).

Therefore, this article looks at discourses surrounding transitions toward lowcarbon energy systems at the national and local levels. The aim of this article is to explore the concept of low-carbon transitions in two different contexts: (i) the ideationally driven processes of institutionalisation and institutional change in Vietnam, where investment in energy infrastructure is framed as a vital national developmental project with international importance; and (ii) energy reform and the role of "climate change mitigation opportunities" in Mexico in light of a historical context of widespread neoliberal political reforms and the market liberalisation of the electricity sector.

The article shows how coherent and contrasting types of politics and forms of governance interact with global, national and local discourses of transformations in energy systems. In both cases, configurations of political institutions and energy systems shape and are shaped by different types of governance choices presented at different scales of policy-making. Interactions between the modes, subjects and objects, and institutions of governance are enabled by the ideational power of the discourses that surround them. What key actors believe, and what coordinative discourse they share, can considerably influence the impact of transformations of energy infrastructure.

The institutional approach taken here pays attention to the power in and over ideas in energy governance and shows how certain models of transformation are adopted based on existing socio-economic conditions and political circumstances. By combining an ideational perspective and looking closely at the wider political context of energy systems in transition, we reiterate calls for future research to further enhance the analytical depth and reflexivity in policy-making. We suggest doing this by uncovering the ideational background of the programmatic responses and policy choices that can provide the tools for 
the systematic exploration of possible transition pathways, policy goals and policy strategies from a perspective that goes beyond explanations in terms of governance failures and limited access to resources. Furthermore, governments in both countries would benefit from clarifying energy and CCM laws that contradict national priorities: for instance, in Mexico, priorities for energy development and water allocation, and in Vietnam, the centralized approach to renewable energy, are contradictory and cannot both have an equally high priority. Despite the rhetoric surrounding energy reforms and market liberalization in both Vietnam and Mexico, both governments retain centralized power de facto over renewable energy and CCM policies and programs, not only because of infrastructure lock-ins, but also through centralized institutional and strategic ideation. Institutional arrangements for energy and CCM need to be reworked to consider polycentric ideas and views that acknowledge the need for decentralization at various levels while still forming part of larger infrastructure ecosystems.

In conclusion, we reveal that centralized, traditional models of fossil fuelbased energy supplies continue to dominate in Mexico and Vietnam despite continued energy sector reforms that have introduced elements of liberalization in the power sector and in energy governance. Our findings suggest that both governments maintain an exclusive rather than inclusive form of energy governance and retain centralized power over renewable energy and climate change mitigation responses. This is not only because of technological infrastructural lock-ins, it is also justified and legitimized through the background ideas of energy supply and access security, populist appeals to maintain socio-economic stability and by seeing green growth as a source of continuous economic growth. 


\section{CONCLUDING REMARKS}

This section summarises the key insights from each of the four appended articles by addressing the overall question:

How do ideas of what constitutes sustainability and transformational change influence governance towards a low-carbon society?

After first providing a synthesis of the key arguments in each individual article of this dissertation by compilation, I outline the principal insights of this research. A discussion of the relevance of this work for policy-making practice follows.

\subsection{Answering research questions}

Responding to calls for an expansion of the political analysis of climate change and low-carbon transformation interventions in developing countries, this dissertation set to explore to what degree governance of climate change mitigation is framed by ideas about what constitutes a long-term transformation and how to ensure it. This implied looking at a multitude of perspectives in a variety of political and institutional circumstances, examining how issues around low-carbon transformations are represented in policy-making, how new ideas translate into practices and how actors determine the meaning systems of institutions.

I have approached this task through two research objectives. First, I developed a conceptual understanding of the nexus between ideas and institutions in governance and outlined the mechanisms of ideational power in fostering or impeding change, as suggested in the literature. Secondly, I tested conceptual understanding by exploring how ideas and discourses are manifested in policy frameworks, translated by actors and institutionalised in public policy and governance arrangements in four separate case studies. It has been possible to unravel which ideas matter in explaining how 
perspectives on development frame and interpret climate-compatible sustainable development and what kind of policy objectives, and governance and policy instruments they imply. Who translates them and how does that define what action is preferred?

The key argument in this dissertation is that ideas are as important as formal institutions in constraining or facilitating the possibility of social change at a time when the debate on development trajectories is expected to reflect on the responses to the climate change challenge. To explore the argument, three supporting research questions were put forward:

a) What are the ideas and discourses that impact climate change mitigation governance and policy-making?

b) How are the ideas behind political choices translated into institutions and policy-making practices of climate change mitigation and lowcarbon development in different contexts?

c) How and when do ideas of what constitutes sustainability, low-carbon development and transformational change become influential in facilitating or impeding institutional change?

The analysis uncovered a set of distinct shared background ideas and discourses regarding climate-compatible development pathways. The key actors that were especially important in informing governance approaches, policy instruments and institutional development were identified.

\subsubsection{The construction of meaning: ideas, discourses and storylines}

The narrow range of complementary, cooperating and competing discourses is consistent with the trends observed in previous research. Even though discourses vary, the results suggest that a common prevalence of neoliberal ideas and techno-managerial solutions to ecological modernisation consistently frames the issue as one not only of policy development, but also of knowledge management and material infrastructure. Incumbent national governments, northern and national experts and market participants translate such framings of policy problems. The storylines and discourses, coupled with a background rationale for the contemporary global climate regime, are creating a conducive environment for the discursive strategies 
that support solutions that are narrowly focused on short-term cost efficiencies and incremental change. While the diversity of conceptualisations can be viewed as conducive to innovation and change, this also breeds uncertainty. The vague and ambiguous discourses that can be bent to fit the ideas that shape actors' pre-existing interests support the existing power arrangements.

In the overlapping policy arenas of climate change, low-carbon development and the energy sector in Vietnam, two meta-discourses of ecological modernisation and green growth (or green environmentalism), are constructing climate change responses to accommodate, deliberate and legitimise existing policy responses and practices. They serve as 'actors' ideational legitimation of their interpretation' (Carstensen and Schmidt 2016: 1033) of the sustainable development model. Climate change mitigation is framed as (i) an opportunity for development and modernisation, and (ii) part of green growth as a prerequisite and source of economic growth to secure socio-economic achievement of the reforms. Moreover, the dominance of the international techno-managerial discourse of ecological modernisation over national policy, as manifested among others in the baseline requirements discussed in Article II, impeded institutionalisation of more transformational responses in domestic policy arenas.

Furthermore, the case study in the Article III exemplifies how the mainstreaming of climate change mitigation and low-carbon development agendas, is impeded by the pervasiveness of the international discourse. Article IV discusses what electricity and material infrastructure mean in two countries that ground their embracing of the low-carbon development pathway in the ideas defined within the global climate regime. The article highlights how the seemingly similar idea of low-carbon development is appealed to through and given meaning by invoking distinct rationales, as well as being bounded by the particularities of the institutional and political contexts. In the case of the reforms of the electricity sector in Mexico, the climate change mitigation agenda is supported by a rationale of the appropriateness of lowcarbon technologies as to ensure providing solutions to the oil resources depletion. Climate change mitigation provides opportunities for restructuring of the energy sector in Mexico within a historical context of neoliberal political reforms and market liberalisation of the electricity sector. In Vietnam, on the other hand, electricity is framed as a vital national development project of international importance. 


\subsubsection{The power of ideas}

It is hard to provide a compelling account of the enduring impacts of ideas and discursive practices on the long-term development of institutions and social transformation. However, the present analysis has shown how existing and emerging discourses and argumentative strategies were tied to accepted discursive formats. In the case of the national arena of climate change mitigation in Vietnam, the power over ideas evidently lies with those involved in the production of a global discourse on climate change mitigation. Experts and technocrats used their epistemic power to limit the scope of debate and to frame the policy response and the imaginable tools that guide development for instance, in developing a NAMA in the buildings sector in Vietnam or in the broader context of climate change mitigation. These individuals discursively produced a normatively appealing and cognitively convincing storyline, which suited domestic institutional contexts and interests. The limited autonomy of both individual and institutional actors in setting the agenda bound policy solutions to the 'permitted' framings. Similarly, in Vietnam the state has historically defined the development of the electricity sector by establishing a compelling discourse of electricity as a cornerstone of socio-economic development and security. The credibility and acceptability of this discourse is used strategically to promote the notions of green growth and opportunities for technological modernisation while introducing climate change mitigation measures.

Nevertheless, while discourses were important in explaining the emergence of the mitigation policy initiatives, they accompanied institutional variables in the institutionalisation of ideational and institutional path dependencies, as well peculiar structural features of the governance of climate change mitigation in the contemporary state of Vietnam. It may be difficult to implement the idea's programmatic elements if they do not suit the technical and administrative capacities of the implementing agency. In Vietnam, for instance, institutionally diffused authority over public policy among different governmental agencies can impede the implementation of strategies based on new ideas, as multiple agencies share authority and must coordinate their actions. However, the institutional fragmentation, lack of transparency and limited authority of the Ministry of Environment and Natural Resources over the development of sectoral policies and the national budget, along with the hierarchical coordination of governance, constitute the most significant barriers to national policy-making. The inquiry into the underlying 
assumptions of political choices and the degree of institutionalisation of the climate change mitigation discourse in Vietnam suggests that the dominance of the state and its collaboration with transnational agents limits the space for wider political engagement and alternative framings of low-carbon development.

Likewise, in the case of VCM, development power over the construction of discourses around sustainability lies with a single group of project developers predominately from European countries. In the case of policy-making in the electricity subsector, in both Vietnam and Mexico, the degree to which authority over the implementation of policy is concentrated in the state is particularly important. The influence over the policy agenda is unevenly distributed and subject to fewer legislative veto opportunities here. The more influential actors in terms of institutional position and authority and access to resources show a capacity to resist alternative discourses and exclude alternative actors, as has been demonstrated in relation to sectoral and national climate change mitigation policies in Vietnam. In the case of the development of the electricity sector in Mexico, neoliberal political reforms and a widely accepted market liberalisation agenda allowed a wider variety of policy solutions in infrastructural development. Nevertheless the coalition of government actors has a defining role in framing the discourse around climate change mitigation in the electricity sector, thus dominating the discursive framing of the policy issues involved.

Analysis has also suggested that a clash of emerging storylines with established discourses is not the only way to achieve policy change. The case of the development of the electricity sector in Mexico demonstrates that a new storyline that is largely in line with the dominant development discourse can also lead to quite substantial policy and institutional change by rallying existing interests and building coalitions across actors that do not necessarily have shared interests. Institutional change emerges in all cases, not from within a political and institutional vacuum, but as part of wider sociotechnological assemblages reflecting how power in, over and through ideas becomes diffused within low-carbon development and climate change mitigation policies. This reflects the re-focusing of governance in the energy sector that is currently taking place. The concerns about the potential for transformation going beyond technological advancement remain. 


\subsection{Contribution}

This dissertation has drawn attention to the importance of the underlying assumptions of political actions for transformational change. By highlighting the role of ideas, the results provide an input into scholarly debate and policymaking alike. This dissertation makes three contributions.

As a contribution to the academic debate in the political science literature, it addresses the limitations of the literature and responds to the consequent calls for extended attention to be paid to the domestic politics of low-carbon development and climate change mitigation action in developing countries.

Conceptually it contributes by demonstrating how ideas are able to provide valuable explanations in uncovering the assumptions and drivers of political and policy choices beyond materialist interest-based explanations. To explain why transformation is a political and institutional matter, it tests the analytical framework. Here the contribution consists in adopting a combination of perspectives on institutional change and integrating insights from governance theory and the constructivist institutional perspective, which has the potential to shed light on endogenous sources of change and thus to identify the potential source of transformation. Empirically this work adds to scholarship in the emerging low-carbon development policy field in developing countries contexts.

From the policy practice perspective, this contribution directs attention to the often neglected politics of the guiding paradigm in institutional development around climate change mitigation policy-making. This work shows how discursive institutionalisation is important in understanding the multiple aspects of low-carbon development, policy-making, development practice and often material infrastructure.

\subsection{Overall conclusion}

The notion of transformational change, which is gaining momentum globally, offers an opportunity to translate the long-term goals of sustainability into development aspirations. However, what is 'transformational change' on the philosophical, programmatic and policy levels needs to be determined and agreed in order to create a common, comprehensive and inclusive discourse for 
translation into political action. New storylines and discourses in policy arenas can determine the direction of institutional change by reframing or redefining policy problems, including new actors and/or altering the perceived interests of actors. Based on the empirical evidence in this dissertation, it is argued that these struggles over meaning define policy solutions, thus enabling, shaping and constraining policy mechanisms working towards the transformation of, for example, energy systems in important ways.

There are four main insights here. First, in conceptual terms this dissertation has been instructive in showing that embedded ideas, discourses and frameworks, such as those concerning the role of electricity in socio-economic development, the role of knowledge in policy-making or the very fundamental assumption about low-carbon development, influence governance agendas and practice regarding climate change mitigation in a number of ways. It is argued that policy choices in infrastructure development or the energy sector and mitigation actions are rooted not only in self-interest, material circumstances and goals-means rationality, but also in understandings of what a low-carbon future means and how it should be governed. Conceptualisations of policy problems and solutions in the cases presented here have resulted in incumbent actors resorting to quite conventional instruments in the absence of alternative and/or more transformational visions of development.

Secondly, the dissertation has highlighted how actors translate the principles of the policy solutions of the dominant discourses associated with the ideas and principles of liberalisation, ecological modernisation and green environmentalism by invoking and appealing to the arguments, storylines and discourses around climate change mitigation. In their turn, therefore, they are making climate change mitigation and low-carbon agendas more acceptable within sectoral policies. This is achieved by adding credibility to the discursive coalition of powerful coalitions of incumbents, thus limiting the participation of actors with marginal and/or alternative discourses and pre-empting the possibility of a debate envisaging more transformational change, instead of having incremental changes occur alongside the neoliberal market logic.

Thirdly, the established global discourse on climate change grounded in the principles of ecological modernisation resonates with the national development agenda and is advocated by the coalition of northern experts and the national technocratic bureaucracy by claiming knowledge and expertise through their power over ideas. Due to the institutional positioning of the 
technocratic experts, the political capacity of policy-makers who are excluded from the technical debates around issues of climate change mitigation is restricted. As a result, arguments for the adoption of certain policy solutions are often incompatible with the distinctive institutional context and governance practices. Uncovering the ideational background of programmatic responses and policy choices can provide tools for the systematic exploration of possible transitions and the establishment of comprehensive coordinating discourses about possible transformational pathways.

Lastly, the controversy between the stated principles and conceptualisations of development is impeding institutional change. Thus, it potentially causes institutional fragmentation and institutional sectoral cooperation. While there are no fundamental shifts in the background and programmatic ideas about transformational change, dominant incumbent actors' legitimise conservative ideas further. They use their ideational ability within the interpretive framework to frame the institutional context and to assign values to policy choices, thus making the perpetuation of existing interests actionable. Ideas therefore become further embedded in development trajectories due not only to their power, but also to the power executed over and through them. The political influence of the prevailing and advancing neoliberal ideas is not necessarily opposed to the acceleration of mitigation action. By persuading actors of the appropriateness of actions from the perspective of economic rationale, alternative and incumbent actors may reframe policy solutions by questioning the underlying assumptions of policy choices. However, this furthers the concerns that economic rationale is employed in the climate policy arena to justify the need for growth, thus normalizing the temporal necessity of fossil fuels. Moreover, ambiguous interpretations of what constitutes meaningful change and the limited toolbox of measures offered within the neoliberal framework and ecological modernisation discourse threaten to result in 'mock compliance'.

Measures institutionalising long-term transformations are unlikely to be effective if the ideas involved lack the ability to develop within the parameters set by the governance regime. Ideas about transformation should not only be technically or economically feasible, but also feasible politically and ideationally if they are to be translated into action. I argue that the effects of any efforts to transform governance activity at any level are likely to be restricted if they fail to address political and ideational power across multiple levels of governance. Transformational strategies that are based on 
universalistic expectations, are restricted to a narrow choice of instruments and engage a limited range of actors are less likely to be successful. 


\section{8}

\section{POLICY RELEVANCE}

Although this dissertation has aimed to provide analytical insights rather than deliver policy recommendations, the questions it has explored are pertinent to the current problems in climate change policy and practice. The most important message for policy-makers to emerge out of this work is the need to recognise that climate change mitigation actions pose political challenges, and not just economic or technological ones. Technological lock-ins, socio-economic path dependencies and institutional stickiness all need to be addressed. The insights gained by the study have possible implications for policy-making practice and are highlighted below. Policy-makers should therefore acknowledge:

First, the need for reflecting on mitigation solutions by considering diverse contexts. Policy-making assumptions, the political context and institutional contradictions should be made more transparent and could lower the barriers to co-operation, address trade-offs and help bring forward innovative policy solutions. Notably, in the context of countries that have recently embarked on low-carbon development pathways, bringing together the climate change and 'green growth' agendas requires strong political stimuli to leverage the policy synergies and limit institutional incoherencies that go beyond the policy arenas of climate change alone. Progress with governance and institutional interventions need to aim for strengthened consensus-building around policy goals and policy strategies. These include not only the coordination of target setting or the alignment of policy tools, but also the strengthening of implementation and the enforcement of policy. However, these originate essentially from a consensus on the end-goal of the transformation and the ways in which to move towards sustainably. This could be achieved with enhanced analytical depth and reflexivity in policy-making.

Second, recognition is needed that institutional change, and thus the coevolution of technical and institutional structures, is informed by the persistence of or shift in the background ideas of what development is about. 
The political and economic contexts of development, as well as the envisioning and basis of its ideational background, cannot be easily dismissed. Policymakers need to be cognizant of the importance of how policy strategies are constituted by particular discourses of national development and sustainability. Considering decarbonisation and sustainability as outwardly easy to comprehend and related to ideas based on universalistic rationales might leave the assumptions of development unchallenged and prevent the exploration of new areas of governance and policy development. Institutional fragmentation lies beyond the formal institutions of government and traditional forms of governance, as institutional development is politically and ideationally loaded. Institutional, sectoral, financial and technological responses are likely to be restricted on multiple levels if they fail to address the underlying assumptions of policy choices. More contextualised understanding of the ideas behind institutions can help policy-makers recognise non-obvious accounts of how public policy unfolds around the governance of sustainability, which are often seen as unproblematic.

The donor community, in providing assistance for low-carbon development, should not shy away from tensions within domestic political systems. They should try to bring politics back into discussions of policy options while negotiating the conditions in which international actors (experts, policy entrepreneurs, the private sector, transnational agencies) may meaningfully contribute to long-term low-carbon development and inclusive, lasting climate change mitigation policies. The recommendations offered need to reflect the realities of political systems and the motivations for actions regarding climate change mitigation. If the visions of transformational change are to alter modes of governance, the ideational background needs to be confronted by their advocates, and reflexivity regarding the particulars of the institutional context needs to be improved.

National policy-making will benefit from paying increased attention to the rationale inherent in political choices. A necessary step is to establish comprehensive frameworks of what climate-compatible development entails. Institutional measures to address the priorities of climate-compatible development and to ensure progress in convergence across sectors can be strengthened by means of a less ambiguous and comprehensive framework to facilitate cross-sectoral coordination and cooperation among multiple actors. Paying attention to framings of problems and recognising the diversity of multi-actor perspectives may facilitate novel responses to climate change and 
enable more inclusive forms of governance, as well as throwing light on the fundamental incompatibility between and limited reach of generalised policy solutions and technological fixes. External advisers and local reform advocates who are seeking to transform domestic institutions so that they conform to prevailing models need to focus on how to fit long-term climate change mitigation agendas within the parameters set by the existing governance regimes. Increased capacity development efforts, regulatory and legislative progress and the upgrading of institutional arrangements, which are often prescribed by development agencies and welcomed by national governments, are unlikely to be effective in institutionalising low-carbon transformation if they lack the ability to develop within their particular institutional contexts. 


\section{REFERENCES}

Aberbach, J.D. and Rockman, B.A., 2002. Conducting and coding elite interviews. Political Science and Politics, 35(4), pp. 673-676.

Acemoglu, D., Johnson, S. and Robinson, J.A., 2005. Institutions as a fundamental cause of long-run growth. In: P. Aghion and S. N. Durlauf (eds.). Handbook of economic growth, 1, Oxford: North Holland, pp. 385-472.

Adger, N. W., Benjaminsen, T. A., Brown, K. and Svarstad, H., 2001. Advancing a political ecology of global environmental discourses. Development and Change, 32(4), pp. 681-715.

Agrawal, A., Kononen, M. and Perrin, N., 2008. The role of local institutions in adaptation to climate change, social dimensions of climate change. Washington, DC: The World Bank.

Alvesson, M. and Sköldberg, K., 2009. Reflexive methodology: new vistas for qualitative research. London, UK: Sage Publications.

Andonova, L.B., Betsill, M.M. and Bulkeley, H., 2009. Transnational climate governance. Global environmental politics, 9(2), pp. 52-73.

Arnall, A., Kothari, U. and Kelman, I., 2013. Introduction to politics of climate change: discourses of policy and practice in developing countries. The Geographical Journal, 180(2), pp. 98-101.

Arts, B. and Buizer, M., 2009. Forests, discourses, institutions: a discursive-institutional analysis of global forest governance. Forest Policy and Economics, 11(5-6), pp. 340-347.

Arts, B. and Leroy, P. (eds.), 2006. Institutional dynamics in environmental governance. Dordrecht, The Netherlands: Springer Netherlands.

Arts, B. and van Tatenhove, J., 2004. Policy and power: a conceptual framework between the 'old' and 'new' policy idioms. Policy Sciences, 37(3-4), pp. 339-356.

Arts, B., Leroy, P. and Tatenhove, J., 2006. Political modernisation and policy arrangements: a framework for understanding environmental policy change. Public Organisation Review, 6(2), pp. 93-106.

Arts, B., Appelstrand, M. and Kleinschmit, D., 2010. 4 Discourses, actors and instruments in international forest governance. In: J. Rayner, A. Buck and P. Katila (eds.). Embracing complexity: meeting the challenges of international forest governance. A global assessment report, (28). Vienna: IUFRO (International Union of Forestry Research Organizations) Secretariat.

Bäckstrand, K. and Lövbrand, E. 2007. Climate governance beyond 2012: competing discourses of green governmentality, ecological modernisation and civic environmentalism. In: M.E. Pettenger (ed.). The social construction of climate change. Power, knowledge, norms, discourses. Farnham: Ashgate Publishing, pp. 123-147.

Barnett, M. and Duvall, R., 2005. Power in international politics. International Organisation, 59(01), pp. 39-75. 
Bauer, M.W. and Gaskell, G. (eds.), 2000. Qualitative research with text, image and sound. London, UK: Sage Publications.

Baumgartner, F.R., 2014. Ideas, paradigms and confusions. Journal of European Public Policy, 21(3), pp. 475-480.

Beamer, G., 2002. Elite interviews and state politics research. State Politics and Policy Quarterly, 2(1), pp. 86-96.

Béland, D. and Cox, R.H., 2011. Introduction: ideas and politics. In: D. Béland and R. H. Cox (eds.). Ideas and politics in social science research. New York, NY: Oxford University Press, pp. 3-20.

Béland, D. and Waddan, A., 2012. The politics of policy change: welfare, Medicare, and social security reform in the United States. Washington, DC: Georgetown University Press.

Béland, D., 2009. Ideas, institutions, and policy change. Journal of European Public Policy, 16(5), pp. 701-718.

Béland, D., 2016. Kingdon reconsidered: ideas, interests and institutions in comparative policy analysis. Journal of Comparative Policy Analysis: Research and Practice, 18(3), pp. 228-242.

Bell, S., 2011. Do we really need a new 'constructivist institutionalism' to explain institutional change? British Journal of Political Science, 41(4), pp. 883-906.

Berman, S., 2012. Ideational theorizing in the social Sciences since 'policy paradigms, social learning, and the state'. Governance, 26(2), pp. 217-237.

Biermann, F. and Dingwerth, K., 2004. Global environmental change and the nation state. Global Environmental Politics, 4(1), pp. 1-22.

Biermann, F. et al., 2009. The fragmentation of global governance architectures: a framework for analysis. Global Environmental Politics, 9(4), pp. 14-40.

Biermann, F. et al., 2012. Transforming governance and institutions for global sustainability: key insights from the Earth System Governance Project. Current Opinion in Environmental Sustainability, 4(1), pp. 51-60.

Blatter, J., 2012. Forms of political governance: theoretical foundations and ideal types. Working Paper 07. Lucerne, Switzerland: University of Lucerne.

Blyth, M., 2002. Institutions and ideas. In: D. Marsh and G. Stoker (eds.). Theory and methods in political science. Houndmills, UK and New York, NY: Palgrave Macmillan, pp. 292-310.

Blyth, M., 2003. Structures do not come with an instruction sheet: interests, ideas, and progress in political science. Perspectives on Politics, 1(4), pp. 695-706.

Blyth, M., 2015. The new ideas scholarship in the mirror of historical institutionalism: a case of old whines in new bottles? Journal of European Public Policy, 23(3), pp. 464-471.

Blyth, M., Helgadóttir, O. and Kring, W., 2016. Ideas and historical institutionalism. In: O. 
Fioretos, T.G. Falleti and A. Scheingate (eds.). The Oxford handbook of historical institutionalism. Oxford, UK: Oxford University Press, pp. 142-162.

Bogaert, D., Cliquet, A. and Maes, F., 2009. Designation of marine protected areas in Belgium: a legal and ecological success? Marine Policy, 33(6), pp. 878-886.

Börzel, T.A. and Risse, T., 2010. Governance without a state: can it work? Regulation and Governance, 4(2), pp. 113-134.

Bryman, A., 2012. Social Research Methods. Oxford: Oxford University Press.

Bulkeley, H., 2005. Reconfiguring environmental governance: towards a politics of scales and networks. Political Geography, 24(8), pp. 875-902.

Bumpus, A.G., Henríquez, B.L.P., Okereke, C. and Tansey, J., 2014. Carbon governance, business transformation and climate change. In: A. Bumpus (ed.). Carbon governance, climate change and business transformation. London, UK: Routledge, pp. 1-12.

Burch, S., 2011. Sustainable development paths: investigating the roots of local policy responses to climate change. Sustainable Development, 19(3), pp. 176-188.

Bygnes, S., 2008. Interviewing people-oriented elites. Eurosphere Online Working Paper Series. Bergen, Norway: University of Bergen, pp. 1-15.

Campbell, J.L., 2004. Institutional Change and Globalisation, Princeton, NJ: Princeton University Press.

Campbell, J.L. and Pedersen, O.K., 2001. The rise of neoliberalism and institutional analysis. Princeton, NJ: Princeton University Press.

Campbell, J.L., 2002. Ideas, politics, and public policy. Annual Review of Sociology, 28(1), pp. $21-38$.

Carr, E.C. and Worth, A., 2001. The use of the telephone interview for research. Nursing Times Research, 6(1), pp. 511-524.

Carstensen, M.B. and Schmidt, V.A., 2016. Power through, over and in ideas: conceptualizing ideational power in discursive institutionalism. Journal of European Public Policy, 23(3), pp. 318-337.

Carstensen, M.B., 2011. Ideas are not as stable as political scientists want them to be: a theory of incremental ideational change. Political Studies, 59(3), pp. 596-615.

Cleaver, F. and De Koning, J., 2015. Furthering critical institutionalism. International Journal of the Commons, 9(1), pp. 1-18.

Cleaver, F., 2002. Reinventing institutions: bricolage and the social embeddedness of natural resource management. The European Journal of Development Research, 14(2), pp. 11-30.

Clemens, E.S. and Cook, J.M., 1999. Politics and institutionalism: explaining durability and change. Annual Review of Sociology, 25(1), pp. 441-466.

Conca, K., 2005. Old states in new bottles? The hybridisation of authority in global 
environmental governance. In: J. Barry and R. Eckersley (eds.). The state and the global ecological crisis. Cambridge, MA and London, UK: MIT Press, pp. 181-206.

Crawford, S.E. and Ostrom, E., 1995. A grammar of institutions. American Political Science Review, 89(03), pp. 582-600.

Crepaz, M.M.L. and Damron, R., 2009. Constructing tolerance. Comparative Political Studies, 42(3), pp. 437-463.

Creswell, J.W., 2012. Qualitative inquiry and research design: choosing among five approaches. London, UK: Sage Publications.

Dacin, M.T., Goodstein, J. and Scott, W.R., 2002. Institutional theory and institutional change: introduction to the special research forum. Academy of Management Journal, 45(1), pp. 45-56.

Darden, K.A., 2009. Economic liberalism and its rivals: the formation of international institutions among the Post-Soviet States. Cambridge: Cambridge University Press.

de Jong, W., Arts, B. and Krott, M., 2012. Political theory in forest policy science. Forest Policy and Economics, 16, pp. 1-6.

Death, C., 2014. The green economy in South Africa: global discourses and local politics. Politikon, 41(1), pp. 1-22.

Death, C., 2015. Four discourses of the green economy in the global South. Third World Quarterly, 37(12), pp. 2207-2224.

Delaney, K.J., 2007. Methodological dilemmas and opportunities in interviewing Organisational elites. Sociology Compass, 1(1), pp. 208-221.

Dempster, P.G., Woods, D.K. and Wright, J., 2013. Using CAQDAS in the analysis of foundation trust hospitals in the National Health Service: mustard seed searches as an aid to analytic efficiency. Forum: Qualitative Social Research, 14(2). Available from: http://www.qualitative-research.net/index.php/fqs/article/view/1876 [Accessed 4 Feb. 2014]

den Besten, J.W., Arts, B. and Verkooijen, P., 2014. The evolution of REDD+: an analysis of discursive-institutional dynamics. Environmental Science and Policy, 35, pp. 40-48.

Denzin, N.K., 2012. Triangulation 2.0. Journal of Mixed Methods Research, 6(2), pp. 80-88.

Dexter, L.A., 2006. Elite and specialized interviewing. Essex: Ecpr Press.

DiMaggio, P.J. and Powell, W.W. (eds.), 1991. The new institutionalism in organisational analysis (Vol. 17). Chicago, IL: The University of Chicago Press.

Dimitrov, R.S., 2005. Hostage to norms: states, institutions and global forest politics. Global Environmental Politics, 5(4), pp. 1-24.

Dingler, J., 2005. The discursive nature of nature: towards a post-modern concept of nature. Journal of Environmental Policy and Planning, 7(3), pp. 209-225. 
Dingwerth, K., Pattberg, P., 2006. Global governance as a perspective on world politics. Global governance: a review of multilateralism and international organizations, 12(2), pp. 185-203.

Dodman, D. and Mitlin, D., 2015. The national and local politics of climate change adaptation in Zimbabwe. Climate and Development, 7(3), pp. 1-12.

Dolsak, N. and Ostrom, E., 2003. The challenges of the commons. In: N. Dolsak and E. Ostrom (eds.). The commons in the new millennium: challenges and adaptations. London, UK and Cambridge, MA: MIT Press, pp. 3-34.

Dryzek, J.S., 1997. The Politics of Earth. Oxford: Oxford University Press.

Dubash, N., Raghunandan, D., Sant, G. and Sreenivas, A., 2013. Indian climate change policy. Economic and Political Weekly, 48(22), pp. 47-62.

Duit, A. Galaz, V., Eckerberg, K. and Ebbesson, J., 2010. Governance, complexity, and resilience. Global Environmental Change, 20(3), pp. 363-368.

Easterly, W., 2008. Design and reform of institutions in LDCs and transition economies institutions: top down or bottom up? American Economic Review: Papers and Proceedings, 98(2), pp. 95-99.

Edenhofer, O. et al., 2014. Climate change 2014: mitigation of climate change. Contribution of Working Group III to the Fifth Assessment Report of the Intergovernmental Panel on Climate Change. Cambridge, UK and New York, NY: Cambridge University Press.

Eggertsson, T., 1997. The old theory of economic policy and the new institutionalism. World Development, 25(8), pp. 1187-1203.

Eguavoen, I., Schulz, K., de Wit, S., Weisser, F. and Müller-Mahn, D., 2015. Political dimensions of climate change adaptation: conceptual reflections and African examples. In: W.L. Filho (ed.). Handbook of climate change adaptation. Berlin, Germany and Heidelberg, Germany: Springer, pp. 1183-1199.

Elzen, B., Geels, F.W. and Green, K. (eds.), 2004. System innovation and the transition to sustainability: theory, evidence and policy. Cheltenham, UK, UK and Northampton, MA: Edward Elgar Publishing.

Emmerij, L., Jolly, R. and Weiss, T.G., 2005. Economic and social thinking at the UN in historical perspective. Development and Change, 36(2), pp. 211-235.

Emerson, R.M., Fretz, R.I. and Shaw, L.L., 2001. Participant observation and field notes. In: P. Atkinson et al. (eds.). Handbook of ethnography. London, UK: Sage Publications, pp. 352-368.

Fairclough, N., 2001. Critical discourse analysis as a method in social scientific research. In: R. Wodak and M. Meyer. Methods of Critical Discourse Analysis. London, UK: Sage Publications, pp. 121-138.

Feindt, P.H. and Oels, A., 2005. Does discourse matter? Discourse analysis in environmental policy making. Journal of Environmental Policy and Planning, 7(3), pp. 161-173. 
Fischer, F. and Gottweis, H., 2013. The argumentative turn in public policy revisited: twenty years later. Critical Policy Studies, 7(4), pp. 425-433.

Fischer, F., 2003. Reframing public policy: discursive politics and deliberative practices, Oxford: Oxford University Press.

Flick, U., 2009. An introduction to qualitative research. London, UK: Sage Publications.

Folke, C., 2006. Resilience: the emergence of a perspective for social-ecological systems analyses. Global Environmental Change, 16(3), pp. 253-267.

Foucault, M. [1975], 1991. Discipline and punish: the birth of the prison. London, UK: Penguin.

Funder, M., Mweemba, C. and Nyambe, I., 2017. The politics of climate change adaptation in development: authority, resource control and state intervention in rural Zambia. The Journal of Development Studies, 00(00), pp. 1-17.

Gaskell, G., 2000. Individual and group interviewing. In: M.W. Bauer and G. Gaskell (eds.). Qualitative research with text, image and sound. London, UK: Sage Publications, pp. 3856.

GCEC, The Global Commission on the Economy and Climate, 2014. New climate economy report. [online] Available from: http://newclimateeconomy.report/2014/wpcontent/uploads/sites/2/2014/08/New-climate-economy_executive-summary_web.pdf [Accessed 8 Apr. 2015]

Geels, F.W., 2004. From sectoral systems of innovation to socio-technical systems. Research Policy, 33(6-7), pp. 897-920.

Geels, F.W., 2011. The multi-level perspective on sustainability transitions: responses to seven criticisms. Environmental Innovation and Societal Transitions, 1(1), pp. 24-40.

George, A.L. and Bennett, A., 2005. Case studies and theory development in the social sciences. Cambridge, MA: MIT Press.

Giddens, A., 1984. The constitution of society. Cambridge: Polity Press.

Gill, R., 2000. Discourse analysis. In: M.W. Bauer and G. Gaskell (eds.). Qualitative research with text, image and sound. London, UK: Sage Publications, pp. 172-190.

Gillard, R. et al., 2016. Transformational responses to climate change: beyond a systems perspective of social change in mitigation and adaptation. Wiley Interdisciplinary Reviews: Climate Change, 7(2), pp. 251-265.

Gofas, A. and Hay, C., 2010. The ideational turn and the persistence of perennial dualisms. In: A. Gofas and C. Hay (eds.). The Role of ideas in political analysis: a portrait of contemporary debates. London, UK and New York, NY: Routledge, pp. 1-11.

Goldstein, J. and Keohane, R.O., 1993. Ideas and foreign policy: an analytical framework. In: J. Goldstein and R.O. Keohane (eds.). Ideas and foreign policy: beliefs, institutions, and political change. Ithaca, NY and London, UK: Cornell University Press, pp. 3-30. 
Graham, L.J., 2005. Discourse analysis and the critical use of Foucault. In: The Australian Association of Research in Education Annual Conference, 27th November - $1^{\text {st }}$ December 2005, Parramatta, Sydney. Unpublished.

Hajer, M.A., 1993. Discourse coalitions and the institutionalization of practice: the case of acid rain in Britain. In: F. Fischer and J. Forester (eds.). The argumentative turn in policy analysis and planning. Durham, UK and London, UK: Duke University Press.

Hajer, M.A. and Versteeg, W., 2005. A decade of discourse analysis of environmental politics: achievements, challenges, perspectives. Journal of environmental Policy and Planning, 7(3), pp. 173-184.

Hajer, M.A., 1995. The politics of environmental discourse: ecological modernisation and the policy process. Oxford: Clarendon Press.

Hall, P.A. and Taylor, R.C.R., 1996. Political science and the three new institutionalisms. Political Studies, 44(5), pp. 936-957.

Hall, P.A. and Soskice, D. (eds.), 2001. Varieties of capitalism: the institutional foundations of comparative advantage. Oxford, UK: Oxford University Press.

Hall, P.A. and Taylor, R.C., 1996. Political science and the three new institutionalisms. Political Studies, 44(5), pp. 936-957.

Hall, P.A. and Thelen, K., 2009. Institutional change in varieties of capitalism. Socio-economic review, 7(1), pp. 7-34.

Hall, P.A., 1993. Policy paradigms, social learning and the state: the case of economic policy making in Britain. Comparative politics, 25(3), pp. 275-296.

Hall, P.A., 1997. The role of interests, institutions, and ideas in the comparative political economy of the industrialized nations. In: M.L. Lichbach and A.S. Zuckerman (eds.). Comparative politics: Rationality, culture, and structure. Cambridge, UK: Cambridge University Press, pp. 174-207.

Hall, P.A., 2010. Historical institutionalism in rationalist and sociological perspective. In: J. Mahoney and K. Thelen (eds.). Explaining institutional change: ambiguity, agency and power. Cambridge, UK: Cambridge University Press, pp. 204-224.

Hanna, S., Folke, C. and Mäler, K.G., 1996. Rights to nature. Washington, DC: Island Press.

Harvey, W.S., 2010. Methodological approaches for interviewing elites. Geography Compass, 4(3), pp. 193-205.

Haxeltine, A., Avelino, F., Wittmayer, J., Kemp, R., Weaver, P., Backhaus, J. and O'riordan, T., 2013. Transformative social innovation: a sustainability transitions perspective on social innovation. In: NESTA Conference social frontiers: the next edge of social science research. Maastricht, The Netherlands: Maastricht University, pp. 14-15.

Hay, C. 2016. Good in a crisis: the ontological institutionalism of social constructivism. New Political Economy, 21(6), pp. 520-535.

Hay, C. 2011. Ideas and the construction of interests. In: D. Béland and R.H. Cox (eds.). Ideas 
and Politics in Social Science Research. Oxford, UK: Oxford University Press, pp. 65-82.

Hay, C., 2002. Political analysis: a critical introduction. Basingstoke, UK: Palgrave Macmillan.

Hay, C., 2006. Political ontology. In: R.E. Goodin and C. Tilly (eds.). The Oxford handbook of contextual political analysis. Oxford, UK: Oxford University Press, pp. 78-96.

Hay, C., 2007. Does ontology trump epistemology? Notes on the directional dependence of ontology and epistemology in political analysis. Politics, 27(2), pp. 115-118.

Héritier, A., 2002. Common goods: reinventing European and international governance. Lanham, MD; Boulder, CO; New York, NY and Oxford, MA: Rowman and Littlefield.

Hodbod, J. and Adger, W.N., 2014. Integrating social-ecological dynamics and resilience into energy systems research. Energy Research and Social Science, 1, pp. 226-231.

Hook, D., 2007. Discourse, knowledge, materiality, history: Foucault and discourse analysis. In: D. Hook (ed.). Foucault, Psychology and the Analytics of Power. Basingstoke, UK: Palgrave Macmillan, pp. 100-137.

Hotimsky, S., Cobb, R. and Bond, A., 2006. Contracts or scripts? A critical review of the application of institutional theories to the study of environmental change. Ecology and Society, 11(1), pp. 1-10.

Jacoby, S.M., 1990. The new institutionalism: what can it learn from the old? Industrial Relations: A Journal of Economy and Society, 29(2), pp. 316-340.

Jepperson, R.L., 1991. Institutions, institutional effects, and institutionalism. The New Institutionalism in Organisational Analysis, 6, pp. 143-163.

Jessop, B., 2011. Metagovernance. In: M. Bevir (ed.). The SAGE handbook of governance. Los Angeles, Calif.: Sage Publications, pp. 106-120.

Jordan, A. and Schout, A., 2006. The coordination of the European Union: exploring the capacities of networked governance. Oxford: Oxford University Press.

Jørgensen, M.W. and Phillips, L.J., 2002. Discourse analysis as theory and method. London, UK: Sage Publications.

Kates, R.W., Travis, W.R. and Wilbanks, T.J., 2012. Transformational adaptation when incremental adaptations to climate change are insufficient. Proceedings of the National Academy of Sciences, 109(19), pp. 7156-7161.

Keman, H., 2006. Parties and government: features of governing in representative democracies. In: R.S. Katz and W. Crothy. Handbook of party politics. London, UK: Sage Publications, pp. 160-174.

Kersbergen, K.V. and Waarden, F.V., 2004. 'Governance' as a bridge between disciplines: cross-disciplinary inspiration regarding shifts in governance and problems of governability, accountability and legitimacy. European Journal of Political Research, 43(2), pp. 143-171. 
Kjaer, P. and Pedersen, O.K., 2001. Translating liberalisation. In: J. Campbell and O.K. Pedersen (eds.). The rise of neoliberalism and institutional analysis. Princeton, NJ: Princeton University Press, pp. 219-48.

Kohler-Koch, B. and Rittberger, B., 2006. Review article: the 'governance turn' in EU studies. JCMS: Journal of Common Market Studies, 44(1), pp. 27-49.

Koning, E.A., 2016. The three institutionalisms and institutional dynamics: understanding endogenous and exogenous change. Journal of Public Policy, 36(4), pp. 639-664.

Kooiman J., 2003. Governing as governance. London, UK: Sage Publications.

Lange, P. et al., 2013. Governing towards sustainability: conceptualizing modes of governance. Journal of Environmental Policy and Planning, 15(3), pp. 403-425.

Lauber, V. and Schenner, E., 2011. The struggle over support schemes for renewable electricity in the European Union: a discursive-institutionalist analysis. Environmental Politics, 20(4), pp. 508-527.

Leroy, P. and Arts, B., 2006. Institutional dynamics in environmental governance. In: B. Arts and P. Leroy (eds.). Institutional dynamics in environmental governance. Dordrecht, The Netherlands: Springer Netherlands, pp. 1-19.

Lieberman, R.C., 2002. Ideas, institutions, and political order: explaining political change. American Political Science Review, 96(4), pp. 697-712.

Liefferink, D., 2006. The dynamics of policy arrangements: turning round the tetrahedron. In: B. Arts and P. Leroy (eds.). Institutional dynamics in environmental governance. Dordrecht, The Netherlands: Springer Netherlands, pp. 45-68.

Lijphart, A., 1999. Patterns of democracy. New Haven, CT and London, UK: Yale University Press.

Lilleker, D.G., 2003. Interviewing the political elite: navigating a potential minefield. Politics, 23(3), pp. 207-214.

Lockwood, M., 2013. What can climate adaptation policy in Sub-Saharan Africa learn from research on governance and politics? Development Policy Review, 31(6), pp. 647-676.

Lockwood, M., 2015. The political dynamics of green transformations: feedback effects in institutional context. In: I. Scoones, M. Leach and P. Newell (eds.). The politics of green transformations. London, UK: Routledge/Earthscan, pp. 86-101.

Loehman, E.T. and Kilgour, D.M., 1998. Designing institutions for environmental and resource management. Cheltenham, UK: Edward Elgar Publishing.

Lowndes, V. and Roberts, M., 2013. Why institutions matter: the new institutionalism in political science. Basingstoke, UK: Palgrave Macmillan.

Lund, C., 2014. Of what is this a case? Analytical movements in qualitative social science research. Human Organisation, 73(3), pp. 224-234.

Lynggaard, K., 2007. The institutional construction of a policy field: a discursive institutional 
perspective on change within the common agricultural policy. Journal of European Public Policy, 14(2), pp. 293-312.

Mahoney, J. and Thelen, K., 2010. A theory of gradual institutional change. In: J. Mahoney and K. Thelen (eds.). Explaining institutional change: ambiguity, agency and power. Cambridge, UK: Cambridge University Press, pp. 1-37.

Mahoney, J. and Thelen, K. (eds.), 2009. Explaining institutional change: ambiguity, agency, and power. Cambridge, UK: Cambridge University Press.

Mahoney, J., 2000. Path dependence in historical sociology. Theory and Society, 29(4), pp. $507-548$.

March, J. and Olsen, J.P., 1989. Rediscovering institutions: the organisational basis of politics. New York, NY: Free Press.

Marks G, Hooghe E., 2004. Contrasting visions of multi-level governance. In: I. Bache and M. Flinders (eds.). Multi-level governance. Oxford, UK: Oxford University Press, pp. 15-30.

Marsh, D. and Stoker, G. (eds.), 2010. Theory and methods in political science. Basingstoke, UK: Palgrave Macmillan.

Marsh, D., 2009. Keeping ideas in their place: in praise of thin constructivism. Australian Journal of Political Science, 44(4), pp. 679-696.

Matthijs, M., 2015. Powerful rules governing the Euro: the perverse logic of German ideas. Journal of European Public Policy, 23(3), pp. 375-391.

Meadowcroft, J., 2011. Environmental Innovation and Societal Transitions. Environmental Innovation and Societal Transitions, 1(1), pp. 70-75.

Meadowcroft, J., Farrell, K.N. and Spangenberg, J., 2005. Developing a framework for sustainability governance in the European Union. International Journal of Sustainable Development, 8(1), pp. 3-11.

Micelotta, E., Lounsbury, M. and Greenwood, R., 2017. Pathways of institutional change: an integrative review and research agenda. Journal of Management, doi:10.1177/0149206317699522.

Mikecz, R., 2012. Interviewing elites: addressing methodological issues. Qualitative Inquiry, 18(6), pp. 482-493.

Mikkelsen, B., 2005. Methods for development work and research: a new guide for practitioners. London, UK: Sage Publications.

Mitchell, R.B., 2006. Problem structure, institutional design, and the relative effectiveness of international environmental agreements. Global Environmental Politics, 6(3), pp. 72-89.

Moore, M.-L. et al., 2014. Studying the complexity of change: toward an analytical framework for understanding deliberate social-ecological transformations. Ecology and Society, 19(4): 54 .

Morris, Z.S., 2009. The truth about interviewing elites. Politics, 29(3), pp. 209-217. 
Mosley, L. (ed.), 2013. Interview research in political science. Ithaca, NY and London, UK: Cornell University Press.

Naess, L.O., Newell, P., Newsham, A., Phillips, J., Quan, J., \& Tanner, T., 2015. Climate policy meets national development contexts: insights from Kenya and Mozambique. Global Environmental Change, 35, pp. 534-544.

Newell, P. and Bulkeley, H., 2016. Landscape for change? International climate policy and energy transitions: evidence from sub-Saharan Africa. Climate Policy, 17(5), pp. 650-663.

Newell, P. and Bumpus, A., 2012. The global political ecology of the clean development mechanism. Global Environmental Politics, 12(4), pp. 49-67.

Newell, P. and Paterson, M., 2010. Climate capitalism: global warming and the transformation of the global economy. Cambridge, UK: Cambridge University Press.

Newell, P., Phillips, J. and Purohit, P., 2011. The political economy of Clean Development in India: CDM and Beyond. IDS Bulletin 42(3), pp. 89-96.

Niemelä, M. and Saarinen, A., 2012. The role of ideas and institutional change in Finnish public sector reform. Policy and Politics, 40(2), pp. 171-191.

North, D.C., 1990. Institutions, institutional change and economic performance. Cambridge, UK: Cambridge University Press.

Nullmeier, F., 2006. The cognitive turn in public policy analysis. G-FORS Working Paper, No. 4. Bremen, Germany.

O'Riordan, T. and Jordan, A., 1999. Institutions, climate change and cultural theory: towards a common analytical framework. Global Environmental Change, 9(2), pp. 81-93.

Oberthür, S. and Gehring, T., 2006. Conceptual foundations of institutional interaction. In: S. Oberthür and T. Gehring (eds.). Institutional interaction in global environmental governance: synergy and conflict among international and EU policies. Cambridge, MA: MIT Press, pp. 19-52.

Ockwell, D. and Rydin, Y., 2006. Conflicting discourses of knowledge: understanding the policy adoption of pro-burning knowledge claims in Cape York Peninsula, Australia. Environmental Politics, 15(3), pp. 379-398.

Ockwell, D. and Byrne, R., 2016. Sustainable energy for all: innovation, technology and propoor green transformations. London, UK and New York, NY: Routledge.

Okereke, C. and Bulkeley, H., 2007. Conceptualizing climate change governance beyond the international regime: a review of four theoretical approaches. Tyndall Centre for Climate Change Research, Working Paper 112. Available from: http://www.tyndall.ac.uk/publications/working_papers/twp112.pdf [Accessed 8 Apr. 2015]

Olsson, P., Galaz, V. and Boonstra, W.J., 2014. Sustainability transformations: a resilience perspective. Ecology and Society, 19(1):1.

Ostrom, E., Gibson, C.C., Shivakumar, S. and Andersson, K., 2002. Aid, incentives, and sustainability: an institutional analysis of development cooperation. In: Sida Studies in 
Evaluation, No. 02/01. Stockholm: Swedish International Development Cooperation Agency.

Ostrom, E., 1986. An agenda for the study of institutions. Public Choice, 48(1), pp. 3-25.

Ostrom, E., 2005. Understanding institutional diversity. Princeton, PA and Oxford, MA: Princeton University Press.

Ostrom, E., 2008a. Political economy of climate change policy. Economic Affairs, 28(3), pp. 2431.

Ostrom, E., 2008b. The challenge of common-pool resources. Environment: Science and Policy for Sustainable Development, 50(4), pp. 8-21.

Ostrom, E., 2010. Institutional analysis and development: elements of the framework in historical perspective. In: C. Crothers (ed.). Historical developments and theoretical approaches in sociology in encyclopedia of life support systems (EOLSS), developed under the auspices of the UNESCO. Oxford, UK: Eolss Publishers.

Ostrom, E., 2011. Governing the commons. Cambridge, UK: Cambridge University Press.

Ostrom, E., 2015. Governing the commons. Cambridge, UK: Cambridge University press.

Paavola, J., 2007. Institutions and environmental governance: a reconceptualisation. Ecological Economics, 63(1), pp. 93-103.

Paavola, J., Gouldson, A. and Kluvánková-Oravská, T., 2009. Interplay of actors, scales, frameworks and regimes in the governance of biodiversity. Environmental Policy and Governance, 19(3), pp. 148-158.

Papadopoulos, I. and Lees, S., 2002. Developing culturally competent researchers. Journal of advanced nursing, 37(3), pp. 258-264.

Parsons, C., 2015. Ideas and power: four intersections and how to show them. Journal of European Public Policy, 23(3), pp. 446-463.

Pegels, A. (ed.), 2014. Green industrial policy in emerging countries. London, UK: Routledge.

Peters, B.G., 2005. Institutional theory in political science. New York, NY: The Continuum International Publishing Group.

Pettenger, M. (ed.) 2007. The social construction of climate change: power, knowledge, norms. Aldershot, UK: Ashgate.

Phillips, N., Lawrence, T.B. and Hardy, C., 2004. Discourse and institutions. Academy of Management Review, 29(4), pp. 635-652.

Phung, D.T.K., 2014. The governance capacity of forest: land allocation policy in Vietnam. $\mathrm{PhD}$, Wageningen University.

Pierre, J. and Peters, B.G. (eds.), 2000. Governance, politics, and the state: political analysis. New York, NY: St. Martin's Press. 
Pierre, J. and Peters, B.G., 2005. Governing complex societies: trajectories and scenarios. Houndmills, UK; Basingstoke, UK and New York, NY: Palgrave Macmillan.

Pierson, P., 2000. Increasing returns, path dependence, and the study of politics. American Political Science Review, 94(2), pp. 251-267.

Pierson, P., 2004. Politics in time: history, institutions, and social analysis. Princeton, NJ: Princeton University Press.

Przeworski, A., 2004. Institutions matter? Government and Opposition, 39(4), pp. 527-540.

Raven, R., van den Bosch, S. and Weterings, R., 2010. Transitions and strategic niche management: towards a competence kit for practitioners. International Journal of Technology Management, 51(1), pp. 57-74.

Rhodes, R.A., 2007. Understanding governance: ten years on. Organisation studies, 28(8), pp. $1243-1264$.

Rhodes, R.A., 1997. Understanding governance: policy networks, governance, reflexivity and accountability. Philadelphia, PA: Open University Press.

Rhodes, R.A., 2000. The governance narrative: key findings and lessons from the ERC's Whitehall Programme. Public Administration, 78(2), pp. 345-363.

Rhodes, R.A., 1996. The new governance: governing without government. Political Studies, 44(4), pp. 652-667.

Ritchie, J., Lewis, J., Nicholls, C.M. and Ormston, R. (eds.). 2013. Qualitative research practice: a guide for social science students and researchers. London, UK: Sage Publications.

Rodrik, D., 2004. Getting institutions right. CESifo DICE Report. Working paper. Cambridge, MA: Harvard University. Unpublished.

Rodrik, D., 2014. When ideas trump interests: preferences, worldviews, and policy innovations. Journal of Economic Perspectives, 28(1), pp. 189-208.

Rodrik, D., Subramanian, A. and Trebbi, F., 2004. Institutions rule: the primacy of institutions over geography and integration in economic development. Journal of Economic Growth, 9(2), pp.131-165.

Rosenau, J.N., 2004. Strong demand, huge Supply. In: I. Bache and M. Flinders (eds.). Multilevel governance. Oxford, UK: Oxford University Press, 31-48.

Ruggie, J., 1998. Constructing the world polity: essays on international institutionalisation. London, UK: Routledge.

Rutherford, M., 1995. The old and the new institutionalism: can bridges be built? Journal of Economic Issues, 29(2), pp. 443-451.

Sabatier, P. and Weible, C., 2007. The advocacy coalition: innovations and clarifications. Theories of the Policy Process, 2, pp. 189-220. 
Saldaña, J., 2015. The coding manual for qualitative researchers. London, UK: Sage.

Sarantakos, S., 2005. Social research: introduction to guidelines on reporting qualitative research. Journal of Advanced Nursing, 42(6), pp. 544-545.

Schmidt, V.A. and Radaelli, C.M., 2004. Policy change and discourse in Europe: conceptual and methodological issues. West European Politics, 27(2), pp. 183-210.

Schmidt, V.A., 2001. The politics of economic adjustment in France and Britain: when does discourse matter? Journal of European Public Policy, 8(2), pp. 247-264.

Schmidt, V.A., 2008. Discursive institutionalism: the explanatory power of ideas and discourse. Annual Review of Political Science, 11, pp. 303-326.

Schmidt, V.A., 2010. Taking ideas and discourse seriously: explaining change through discursive institutionalism as the fourth 'new institutionalism'. European Political Science Review, 2(01), pp. 1-25.

Schmidt, V.A., 2015. Discursive institutionalism: understanding policy in context. In: F. Fischer, et al. (eds.). Handbook of critical policy studies. Cheltenham, UK and Northampton, MA: Edward Elgar Publishing, pp. 171-189.

Scoones, I., Leach, M. and Newell, P. (eds.), 2015. The politics of green transformations. London, UK and New York, NY: Routledge.

Scott, W.R., 2001. Institutions and organisations. Thousand Oaks, Calif.: Sage Publications.

Sharp, L. and Richardson, T., 2001. Reflections on Foucauldian discourse analysis in planning and environmental policy research. Journal of Environmental Policy and Planning, 3(3), pp. 193-209.

Silverman, D., 2005. Instances of sequences? Improving the state of the art of qualitative research. Forum: Qualitative Social Research, 6(3).

Silverman, D., 2013. Doing qualitative research: a practical handbook. London, UK: Sage Publications.

Skowronek, S., 2006. The reassociation of ideas and purposes: racism, liberalism, and the American political tradition. American Political Science Review, 100(3), pp. 385-401.

Smith, A., Voß, J.P. and Grin, J., 2010. Innovation studies and sustainability transitions: the allure of the multi-level perspective and its challenges. Research Policy, 39(4), pp. 435448.

Smith, K.E., 2006. Problematising power relations in 'elite' interviews. Geoforum, 37(4), pp. 643-653.

Somers, M.R. and Block, F., 2005. From poverty to perversity: ideas, markets, and institutions over 200 years of welfare debate. American Sociological Review, 70(2), pp. 260-287.

Sovacool, B.K. and Linnér, B.O., 2016. The perils of climate diplomacy: the political economy of the UNFCCC. In: B.K. Sovacool and B. O. Linnér (eds.). The political economy of climate change adaptation. Basingstoke, UK: Palgrave Macmillan, pp. 110-135. 
Sovacool, B.K., 2012. The political economy of energy poverty: a review of key challenges.. Energy for Sustainable Development, 16(3), pp. 272-282.

Sovacool, B.K., Linnér, B.O. and Goodsite, M.E., 2015. The political economy of climate adaptation. Nature Publishing Group, 5(7), pp. 616-618.

Stanley, L., 2012. Rethinking the definition and role of ontology in political science. Politics, 32 (2), pp. 93-99.

Stern, N. and Rydge, J., 2012. The new energy-industrial revolution and international agreement on climate change. Economics of Energy and Environmental Policy, 1(1), pp. $1-19$.

Stirling, A., 2014. Transforming power: social science and the politics of energy choices. Energy Research and Social Science, 1(2014), pp. 83-95.

Streeck W. and Thelen K., 2005. Introduction: institutional change in advanced political economies. In: W. Streek and K. Thelen (eds.), Beyond continuity: institutional change in advanced political economies. New York, NY: Oxford University Press, pp. 1-39.

Streeck, W. and Thelen, K.A., 2005. Beyond continuity: institutional change in advanced political economies. Oxford, UK: Oxford University Press.

Tanner, T. and Allouche, J., 2011. Towards a new political economy of climate change and development. IDS Bulletin, 42(3), pp. 1-14.

Tanner, T., Mensah, A., Lawson, E.T., Gordon, C., Godfrey-Wood, R. and Cannon, T., 2014. Political economy of climate compatible development: artisanal fisheries and climate change in Ghana. IDS Working Papers, (446), pp. 1-30.

Tansey, O., 2007. Process tracing and elite interviewing: a case for non-probability sampling. PS: Political Science and Politics, 40(04), pp. 765-772.

Termeer, C.J.A.M., Dewulf A. and Biesbroek G.R., 2017. Transformational change: governance interventions for climate change adaptation from a continuous change perspective. Journal of Environmental Planning and Management, 60(4), pp. 558-576.

Thelen, K., 1999. Historical institutionalism in comparative politics. Annual Review of Political Science, 2(1), pp. 369-404.

Thelen, K.A., Longstreth, F. and Steinmo, S. (eds.), 1992. Structuring politics: historical institutionalism in comparative analysis. Cambridge, UK: Cambridge University Press.

Thomas, G., 2011. A typology for the case study in social science following a review of definition, discourse, and structure. Qualitative Inquiry, 17(6), pp. 511-521.

Torfing, J., B. Peters, B.G., Pierre J. and Sorensen E., 2012. Interactive governance: advancing the paradigm. Oxford, UK: Oxford University Press.

Torfing, J., 2005. Discourse theory: achievements, arguments, and challenges. In: D. Howarth and J. Torfing (eds.). Discourse theory in European politics. Basingstoke, UK: Palgrave Macmillan, pp. 1-32. 
Treib, O., Bähr, H. and Falkner, G., 2007. Modes of governance: towards a conceptual clarification. Journal of European Public Policy, 14(1), pp. 1-20.

Underdal, A. and Young, O.R., 2004. Research strategies for the future. In: Underdal, A. and O.R. Young (eds.) Regime consequences: methodological challenges and research challenges. Dordrecht, The Netherlands: Kluwer Academic Publishers, pp. 361-380.

UNEP, 2011. Towards a green economy: pathways to sustainable development and poverty eradication. Available from: www.unep.org/greeneconomy [Accessed 6 Mar. 2017]

van der Zouwen, M., 2006. Dynamics in nature policy practices across the European Union. In: B. Arts and P. Leroy (eds.). Institutional dynamics in environmental governance. Dordrecht, The Netherlands: Springer Academic Publishers, pp. 139-160.

van Tatenhove, J., Arts, B. and Leroy, P. (eds.), 2000. Political modernisation and the environment: the renewal of environmental policy arrangements. Dordrecht, The Netherlands: Kluwer Academic Publishers.

Vennesson, P., 2008. 12 Case studies and process tracing: theories and practices. In: D. Della Porta and M. Keating (eds.). Approaches and methodologies in the social sciences: $a$ pluralist perspective. New York, NY: Cambridge University Press, pp. 223-239.

Verloo, M. and Lombardo, E., 2007. Contested gender equality and policy variety in Europe: Introducing a critical frame analysis approach. In: M. Verloo (ed.). Multiple meanings of gender equality: a critical frame analysis of gender policies in Europe. Budapest, Hungary and New York, NY: Central European University Press, pp. 21-49.

Vogler, J., 2003. Taking institutions seriously: how regime analysis can be relevant to multilevel environmental governance. Global Environmental Politics, 3(2), pp. 25-39.

Walgenbach, P. and Meyer, R., 2008. Neoinstitutionalistische organisationstheorie. Stuttgart, Germany: Kohlhammer Verlag.

Walker, J., 2009. A window of opportunity for critical policy analysis in education? In: Desjardins, R. and Rubenson, K. (eds.). Research of vs research for education policy in an era of transnational policy-making. Saarbrücken, Germany: VDM Verlag, pp. 89-109.

Weaver R.K. and Rockmann, B., 1993. Do institutions matter? Government capabilities in the US and abroad. Washington, DC: Brookings Institution.

Wetherell, M., Taylor, S. and Yates, S.J. (eds.), 2001. Discourse as data: a guide for analysis. London, UK: Sage Publications.

Widmaier, W., 2015. The power of economic ideas - through, over and in - political time: the construction, conversion and crisis of the neoliberal order in the US and UK. Journal of European Public Policy, 23(3), pp. 338-356.

Wiering, M. and Immink, I., 2006. When water management meets spatial planning: a policyarrangements perspective. Environment and Planning C: Government and Policy 24(3), pp. 423-438.

Williamson, O.E., 1995. The institutions and governance of economic development and reform. The World Bank Economic Review, 8 (supplement 1), pp. 171-197. Washington, DC: The 
World Bank.

Willis, K., 2006. Interviewing. In: D. Vandana and R. B. Potter (eds.). Doing development research. London, UK: Sage Publications, pp. 144-152.

Winkler, H. and Dubash, N.K., 2016. Who determines transformational change in development and climate finance? Climate Policy, 16(6), pp. 783-791.

Yanow, D., 1999. Conducting interpretive policy analysis. Thousand Oaks, Calif.: Sage Publications.

Yin, R.K., 1994. Case study research: design and methods. Applied social research methods series. London, UK: Sage Publications.

Yin, R.K., 2013. Case study research: design and methods. London, UK: Sage Publications.

Young, O.R., 2002. The institutional dimensions of environmental change: fit, interplay, and scale. Cambridge, MA: MIT Press.

Young, O.R., 2003. Environmental governance: the role of institutions in causing and confronting environmental problems. International Environmental Agreements: Politics, Law and Economics, 3(4), pp. 377-393.

Young, O.R., 2008. Institutions and environmental change: the scientific legacy of a decade of IDGEC research. In: O. R. Young, L. A. King and H. Schroeder (eds.). Institutions and environmental change, principal findings, applications, and research frontiers. Cambridge, MA: MIT Press, pp. 3-45. 


\section{APPENDICIES}

\section{APPENDIX I. INTERVIEW PROTOCOL}

\section{Vietnam case studies (Article II and III)}

For this study, four different interview guides have been developed for each relevant interviewee type. Interview questions were designed with key openended questions. These were grouped thematically to be used for reference and as prompts if necessary. Prepared beforehand, they were used based on how the conversation unfolded spontaneously in the interview, without the need to refer to the schedule explicitly.

\section{Abbreviations}

CCM climate change mitigation

EE energy efficiency

GG green growth

LCD low-carbon development

NAMA nationally appropriate mitigation action

\section{INTERVIEW PROTOCOL}

Introductory protocol: greetings and an introduction of the project, including verbal informed consent.

\section{BACKGROUND ON THE INTERVIEWEE}

I'd like to begin by asking you some questions about your current job.

1. What is your position at the [organisation]? What are your major responsibilities in your current position? What are the CCM policy activities (or other CCM related) you are involved in?

2. How long have you been with the [organisation]?

\section{INSTITUTIONAL ARRANGEMENTS}


3. How is your organisation involved (have been involved) in climate policy development in Vietnam? What kinds of CCM relevant decision are in your organisational competence/responsibility? On what administrative (national, province, district) level?

- Recap what they're doing and what they're trying to accomplish.

- Probe for history.

4. How could you describe your organisation/institution position in relation to other [stakeholders/agencies] working in CCM policy arena?

- Probe for decision-making process.

- Probe for budget allocations.

- Probe for communication protocols and rules/data exchange/consultations and informal communication.

5. How is your organisation structured in terms of units and staff members involved in CCM/LCD activities/NAMA?

- Probe for the different units that play a role and a number of people and their function.

6. Could you please recall how and when your organisation got involved in CC mitigation/LCDS issue?

- Probe for timeframe, framings / 'reasoning'.

\section{PROCESS QUESTIONS}

7. Please think of recent example of your organisation participation in policy discussion/design/planning. Could you please recall how did you identify mitigation options, budgets for supporting mitigation options, responsible [institution/unit/staff]?

- Probe for the (steps, etc.).

- Probe for the process level of involvement, nature of involvement (how?). Describe a situation in which your organisation had to make a decision on CCM policy/activity. What happened? What action did you take?

8. Could you please describe general decision-making procedures/scheme followed in the policy design (recent CCM/LCD example)?

9. What would be an example of your institution working relation, day-to day activities to other national/regional institutions (most recent example, most involved with, most successful cooperation case)? How do you see the relationship between your institution and institution you are cooperating with? (Please indicate on the organisational map)..

- $\quad$ Probe for processes, daily practices, examples of legislation, lobbying activity.

10. How do you see the relationship between your institution and institution you are overseeing? (Please indicate on the organisational map).

11. What impediments do you face in achieving your policy-making related objectives - in other words who/what do you see standing in your way of access and implementation?

- Probe: What arguments do they make?

- What are recent examples of an issue/your arguments/contra arguments.

12. Who else do you see involved/interested in this issue apart form your organisation/institution?

- $\quad$ Probe for other actors' perception and interrelationship. 


\section{DISCURSIVE INTERACTIONS}

13. Could you please help me clarify my understanding of how the issue of climate change and low-carbon development were introduced in policy arenas of [sector example] in Vietnam and what was the role of your institution/organisation?

14. What in your opinion could be a major obstacle for CCM/LCD policy development and implementation?

- Probe for the problem represented to be in CC mitigation and LCD? What presuppositions and assumptions do underline these representations of a problem?

15. Do you see any relevance of international/national policy to your activities on your level?

16. What is understood by CCM actions and LCD measures in (...)?

17. What are the reforms planned/discussed for the long-term LCD/CCM strategy?

18. What has changed when the LCD issue got introduced into the policy arena/with the NAMA introduction? Was there a need for new institutional arrangements? Do the new institutions fit into existing arrangements? Did you have to restructure, assign new budget lines, allocate and recruit new staff, etc.? How was this discussed in your agency?

\section{BUILDING SECTOR SPECIFIC QUESTIONS (in addition)}

19. What are the key stakeholders in the energy efficiency policy discussion?

20. What is yours organisation involvement, level of administration, activity type?

- Probe: how is organisation involved in/exposed to LCDS/CCM?

- Probe: how is the problem discussed in terms of climate or as efficiency problem?

21. What is the central argument around the EE policy? Could you please recall how was it discussed, initiated (who, why/what is the history/story)?

22. Who is responsible for implementation of the [building codes, other legislation]?

23. Please describe your experience with the process of introducing (new energy efficiency measures for instance).

24. How is your experience of cooperation with other organisations/agencies involved in energy efficiency policy decision (different administrative levels)?

25. What are the major obstacles in policy discussion/design and implementation? What is the long-term strategy?

\section{THEMES EXPLORED AND SPECIFIC QUESTIONS: RESEARCHERS}

26. Please describe you research activities related to policy-making in cc mitigation/building sector.

27. Please give examples of how your research results have been used by policy makers?

28. How do you communicate research results to policy-makers? 
Themes: policy-relevant research areas, perceptions of governance issues in climate change mitigation, assessments of institutional capacities, assessments of policy framings relevant to the policy fields explored, experience of institutional cooperation.

\section{THEMES EXPLORED AND SPECIFIC QUESTIONS: DONOR AGENCIES}

29. What is your agency history of involvement in CCM/LCD in national policy arena in Vietnam (in environmental policy making in general)?

30. Could you please name the policy documents/proposal your agency helped in drafting/preparation? Could you please comment on your organisational experience with the policy-making process/consultations?

- Probe for stakeholder involvement, transparency of discussions/problem definitions.

- What is your perception of the GoV motivation to participate in $\mathrm{CCM}$ and $\mathrm{LCD} / \mathrm{GG}$ ?

Themes: project activities, field experience, perceptions of governance issues in climate change mitigation, assessments of institutional capacities, assessments of policy framings relevant to the policy fields explored. 


\section{APPENDIX II. LIST OF RESPONDENTS (ANONYMISED)}

\section{List of interviews conducted in May 2013 for the case studies presented in Articles II and III of this thesis by compilation.}

1. Programme Leader Renewable Energy, SNV, Netherlands Development Organisation (Vietnam), (audio recording, transcript)

2. Programme Coordinator, Embassy of Finland, (audio recording, transcript)

3. SwedishCentecVietnam, Hanoi, (audio recording, transcript)

4. SwedishCentecVietnam, Hanoi, (audio recording, transcript)

5. Official, Department of Meteorology, Hydrology and Climate Change, Ministry of Natural Resources and Environment (MONRE), (audio recording, transcript)

6. Official, Department of Meteorology, Hydrology and Climate Change, Ministry of Natural Resources and Environment (MONRE), (audio recording, transcript)

7. Project officer, Danish Energy Agency (DEA), Copenhagen, (audio recording, transcript)

List of interviews conducted in February and March 2014 for the case studies presented in Articles II and III of this thesis by compilation.

1. Official, Department of Meteorology, Hydrology and Climate Change (DMHCC), Ministry of Natural Resources and Environment (MONRE), (notes, transcript)

2. Senior official, Department of Meteorology, Hydrology and Climate Change (DMHCC), Ministry of Natural Resources and Environment (MONRE), (audio recording, transcript)

3. Official, Danish Embassy Climate Change Programme, Hanoi, Vietnam, (audio recording, transcript)

4. Official, Danish Embassy Climate Change Programme, DEA, (notes)

5. Senior official, Office of National Committee on Climate Change, Vietnam Ministry of Natural Resources and Environment (MONRE), (audio recording, transcript)

6. Official, Institute of Energy, Ministry of Industry and Trade (MOIT), (audio recording, transcript)

7. Official, International Finance Corporation (IFC) Vietnam, (notes)

8. Official, International Finance Corporation (IFC), (notes)

9. Staff, USAID Vietnam Clean Energy Programme, The United States Agency for International Development, (notes)

10. Consultant, USAID Vietnam Clean Energy Programme, The United States Agency for International Development, (notes)

11. Senior official, Division of Climate Change, Marine and Islands, Institute of Strategy and Policy on Natural Resources and Environment (ISPONRE) (audio recording, transcript)

12. Staff, Sustainable Development Cluster, United Nations Development Program in Vietnam (UNDP Vietnam), (audio recording, transcript)

13. Staff, E4G NGO, (notes) 
14. Staff, E4G NGO, (notes)

15. Staff, Netherlands Development Organisation (SNV), (audio recording, transcript)

16. Staff, Netherlands Development Organisation (SNV), (audio recording, transcript)

17. Staff, NIRAS Vietnam (RCEE-NIRAS JSC), (notes lost)

18. Staff, Energy and Environment Consultancy, JSC

19. Staff, Energy efficiency and renewable energy expert, GIZ (German Development Agency, Deutsche Gesellschaft für Internationale Zusammenarbeit GmbH), (notes)

20. Official, Division of GHG Emission Monitoring and Low-carbon Economy, DMHCC, Ministry of Natural Resources and Environment (MONRE), (audio recording, transcript)

21. Official, Division of GHG Emission Monitoring and Low-carbon Economy (DMHCC), Ministry of Natural Resources and Environment (MONRE), (notes)

22. Senior official, International Cooperation Division, National Institute of Strategy and Policy on Natural Resources and Environment (ISPONRE), (audio recording, transcript)

23. Staff, Sustainable Environment and Natural Resources Management, Food and Agriculture Organisation of the United Nations (FAO), (notes)

24. Senior policy advisor, UNDP Vietnam (notes)

25. Junior technical advisor, GIZ, Office in Da Nang German Development Agency, Deutsche Gesellschaft für Internationale Zusammenarbeit GmbH, (notes)

26. Senior consultant, GIZ, Office in Da Nang German Development Agency, Deutsche Gesellschaft für Internationale Zusammenarbeit $\mathrm{GmbH}$ ), (audio recording)

27. Official, Da Nang Peoples' Committee, (notes)

28. Senior official, Department of Industry and Trade Da Nang (DOIT), (audio recording)

29. Official, Department of Industry and Trade Da Nang (DOIT), (audio recording)

30. Senior official, Department of Natural Resources and Environment Da Nang (DONRE), (audio recording)

31. Official, Department of Planning and Investment Da Nang (DPI), (audio recording)

32. Official, Department of Construction Da Nang (DOC), (notes)

33. Senior official, Department of Construction Da Nang (DOC), (notes)

34. Senior official, Climate Change Coordination Office (CCCO), Department of Natural Resources and Environment Da Nang (DONRE), (audio recording)

35. Senior official, Overseas Vietnamese and INGO Affairs Division Da Nang Department of Foreign Affairs, (notes)

36. Senior official, Ozone Layer Protection Center (OLPC), Ministry of Natural Resources and Environment (MONRE), (audio recording)

37. Official, Department of Science and Technology, Ministry of Construction (MOC), (audio recording)

38. Senior advisor, Japan International Cooperation Agency (JICA), (audio recording)

39. Staff, Japan International Cooperation Agency (JICA), (audio recording)

40. Senior staff, Vietnam Green Buildings Council (VGBC), (notes)

41. Senior advisor, Vietnam Green Buildings Council (VGBC), (notes)

42. Senior official, Science Technology and Energy Efficiency Department, Ministry of Industry and Trade (MOIT), (notes)

43. Official, Industrial Energy Department, Ministry of Planning and Investment (MPI), (notes)

44. Staff, Hanoi’s Energy Efficiency Center, (notes) 
45. Senior official, Science Council, Vietnam Energy Association, (notes)

46. Senior staff, Building Association Vietnam, (notes)

47. (former) Senior official, Department of Science and Technology, Ministry of Construction (MOC), (notes)

48. Official, Department of Science, Education, Natural Resources and Environment (DSENRE), Ministry of Planning and Investment (MPI), (notes)

49. Senior official, Department of Science and Technology, Ministry of Construction (MOC), (audio recording)

50. Senior official, Institute of Meteorology, Hydrology and Environment (IMHEN), Ministry of Natural Resources and Environment (MONRE), (notes)

51. Team assistant, World Bank (WB) Vietnam, (notes)

52. Senior official, International Cooperation Department, Ministry of Natural Resources and Environment (MONRE), (audio recording) 
The dissertation by compilation at DTU consists of two parts. A summary chapter puts the research into context and summarises the main points of the research publications. The research articles are reproduced and may either have been already published or are manuscripts. Articles are reproduced in the dissertation copy with the permission of the publishers and all the authors.

Cover page illustration: (C) Jilian Pelto (watercolours 'Climate Change Data'). Used with permission.

(C) Maryna Henrysson 2017

Printed in Denmark 